\title{
Biblioteca Digital Académica en Bibliotecología y Estudios de la Información
}

Coordinadora

Georgina Araceli Torres Vargas
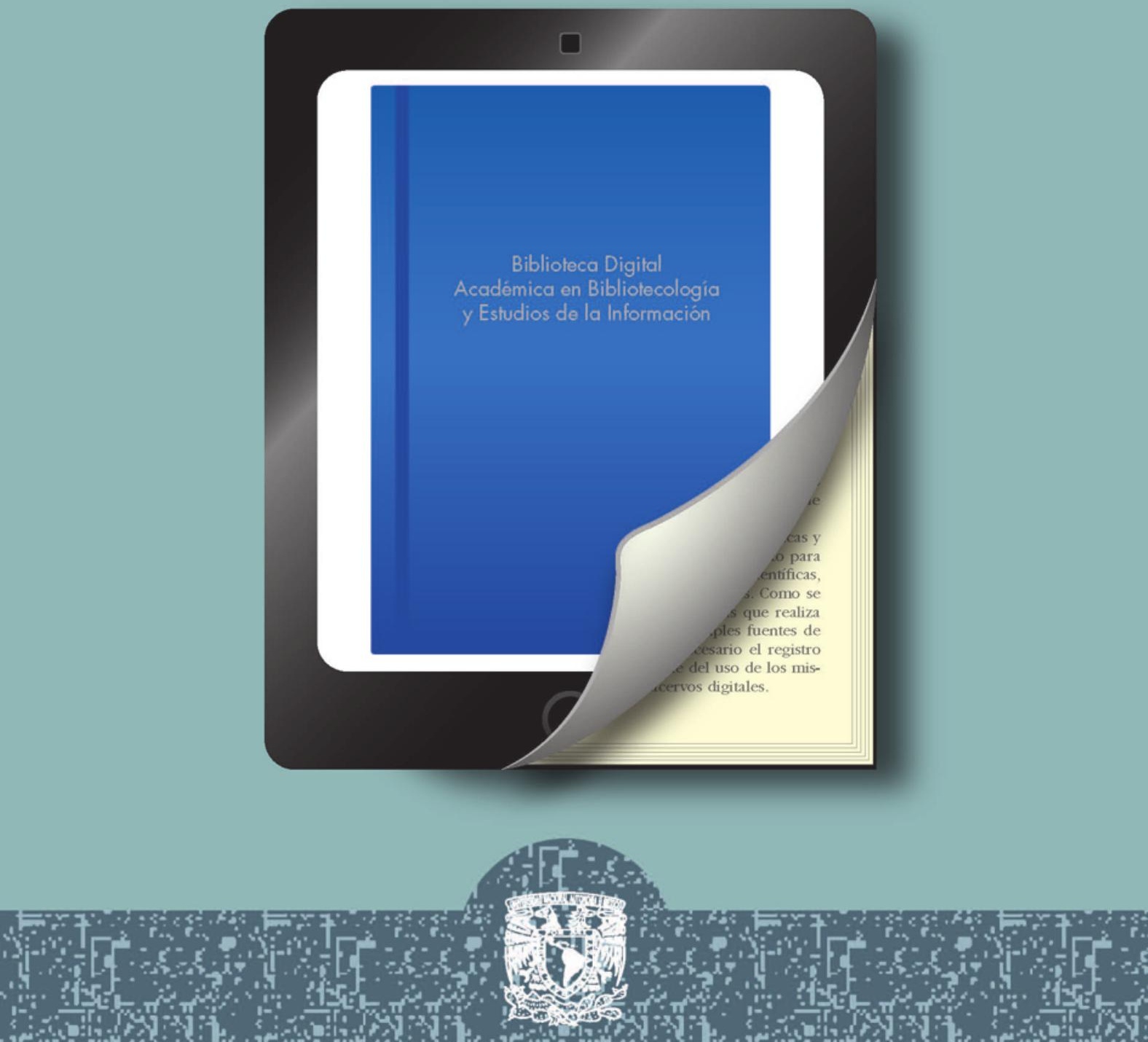
1 - 


\section{La presente obra está bajo una licencia de:}

\section{http://creativecommons.org/licenses/by-nc-sa/3.0/deed.es MX}

\section{Atribución-No Comercial-Licenciamiento Reciproco 3.0 Unported}

Eres libre de:

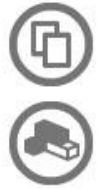

copiar, distribuir y comunicar públicamente la obra

hacer obras derivadas

Bajo las condiciones siguientes:

Atribución - Debes reconocer la autoría de la obra en los términos

especificados por el propio autor o licenciante.

No comercial - No puedes utilizar esta obra para fines comerciales.

Licenciamiento Recíproco - Si alteras, transformas o creas una obra a

partir de esta obra, solo podrás distribuir la obra resultante bajo una licencia

igual a ésta.

\section{Esto es un resumen fácilmente legible del: texto legal (de la licencia completa)}

En los casos que sea usada la presente obra, deben respetarse los términos especificados en esta licencia.
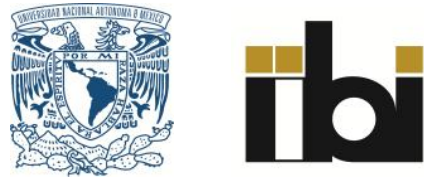
Biblioteca Digital Académica en Bibliotecología y Estudios de la Información 
Investigación realizada gracias al Programa

UNAM-DGAPA-PAPIIT IT 400312

\author{
COLECCIÓN
}

Biblioteca Digital

Instituto de Investigaciones Bibliotecológicas y de la Información 


\title{
Biblioteca Digital Académica en Bibliotecología y Estudios de la Información
}

\author{
Coordinadora \\ Georgina Araceli Torres Vargas
}

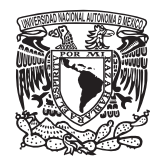

Universidad Nacional Autónoma de México

2013 


\begin{tabular}{|l}
\hline $\begin{array}{l}\text { BA4080 } \\
\text { B53M4 }\end{array}$ \\
$\begin{array}{l}\text { tudios deca digital académica en Bibliotecología y Es- } \\
\text { Araceli Torres Vargas. -- México : UNAM, Instituto de } \\
\text { Investigaciones Bibliotecológicas y de la Información, } \\
2013 .\end{array}$ \\
$\quad$ vii, 155 p. -- (Biblioteca digital) \\
$\quad$ Proyecto PAPIIT IT- 400312 \\
$\quad$ ISBN: 978-607-02-4884-9 \\
1. Bibliotecas Digitales -- Bibliotecología -- México -- \\
Modelo \\
2. Desarrollo de Colecciones -- Bibliotecas Digitales \\
3. Catalogación -- Bibliotecas Digitales. I. Torres Var- \\
gas, \\
Georgina Araceli, coordinadora II. ser.
\end{tabular}

Diseño de portada: Mercedes Torres Serratos

Primera Edición 2013

DR (C) Universidad NACIONAL AUTÓNOMA DE MÉXICO

Ciudad Universitaria, 04510, México D.F.

Impreso y hecho en México

ISBN: 978-607-02-4884-9

Obra financiada con recursos del Programa

UNAM-DGAPA-PAPIIT IT 400312 


\section{Tabla de contenido}

Introducción $\ldots \ldots \ldots \ldots \ldots \ldots \ldots \ldots \ldots \ldots \ldots \ldots \ldots \ldots$ Georgina Araceli Torres Vargas

Biblioteca Digital en Bibliotecología y Estudios de la In-

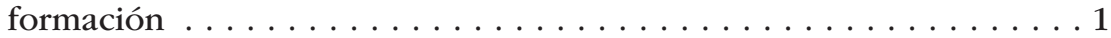

Georgina Araceli Torres Vargas y Ariel Alejandro Rodríguez García

Políticas de informação para bibliotecas digitais: conceitos e componentes . . . . . . . . . . . . . . . . . . . . . . . . . 19

Ana Lúcia Terra

El desarrollo de colecciones de libros electrónicos en las instituciones de educación superior . . . . . . . . . . . . . . . . . 49

Miguel C. Gama Ramírez

Fotografía digital: catalogación y metadatos para la biblio-

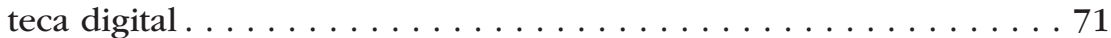
Adriana Monroy Muñoz

Del libro electrónico y las bibliotecas digitales. Estado de la cuestión en España . . . . . . . . . . . . . . . . . . . 97 Francisco José Valentín Ruiz y Juan Miguel Sánchez Vigil

Linked Open Data en la Biblioteca Digital Semántica Académica . . . . . . . . . . . . . . . . . . . . . . . . . . . 137

Eder Ávila Barrientos

Consideraciones finales . . . . . . . . . . . . . . . . 153

Georgina Araceli Torres Vargas 


\section{Introducción}

\footnotetext{
On el Proyecto PAPIIT IT 400312 "Biblioteca Digital en Bibliotecología y Estudios de la Información” (BIDEI), del cual deriva esta publicación, se pretende delimitar las pautas para el desarrollo de una biblioteca digital que albergue colecciones digitales para la comunidad de investigadores en el área de bibliotecología y estudios de la información del Instituto de Investigaciones Bibliotecológicas y de la Información (IIBI), de la Universidad Nacional Autónoma de México.

En este proyecto participan investigadores nacionales e internacionales así como estudiantes del posgrado en Bibliotecología y Estudios de la Información de la UNAM.

En la primera fase del proyecto se realizó un acercamiento a los aspectos que se involucran en la constitución de la biblioteca digital que se pretende concretar. De acuerdo con las características de la comunidad a la que servirá, la biblioteca digital en cuestión será una biblioteca digital académica perfilada al apoyo de lo que hoy se conoce como la e-ciencia. Las políticas de información, las colecciones, los servicios y las formas de acceso a los contenidos se delimitan en este contexto.
}

Georgina Araceli Torres Vargas 


\title{
Biblioteca Digital en Bibliotecología y Estudios de la Información
}

\author{
GEORgINA ARACELI TORRES VARGAS \\ y ARIEl Alejandro Rodríguez GARCÍA \\ Universidad Nacional Autónoma de México
}

\section{INTRODUCCIÓN}

$\mathrm{E}$

n este apartado se mencionan las pautas generales para la creación de la Biblioteca Digital en Bibliotecología y Estudios de la Información (BIDEI) que, como se señaló en la introducción, es producto del desarrollo de un Proyecto PAPIIT-UNAM.

Si bien se parte del contexto mexicano, en específico de aquel que se refiere a la Universidad Nacional Autónoma de México (UNAM), se considera que esta biblioteca se puede replicar en otros ambientes académicos nacionales e internacionales. Muestra de ello es la participación de la Escola Superior de Estudos Industriais e de Gestão (Instituto Politécnico do Porto, Portugal), para diseñar la biblioteca digital y probarla en el contexto de la comunidad de estudiantes y profesores de dicha institución.

El diseño se basa en:

a) Un modelo teórico de la Biblioteca Digital desarrollado en el Instituto de Investigaciones Bibliotecológicas y de la Información.

b) El uso de la técnica de grupos focales con personas de las comunidades participantes para verificar el diseño. 


\section{COMPONENTES BÁSICOS DE LA BIDEI}

La definición instrumental ${ }^{1}$ de biblioteca digital $^{2}$ para el presente trabajo es:

La biblioteca digital (BD) plenamente desarrollada es una colección organizada, con servicios asociados, en la que la información está almacenada en formato digital y es accesible en un sistema de información virtual.

La BIDEI constará de tres componentes básicos (Figura 1):

1. Tecnologías de la Información y la Comunicación necesarias para la $\mathrm{BD}$.

2. Contenidos digitales organizados.

3. Servicios digitales de información.

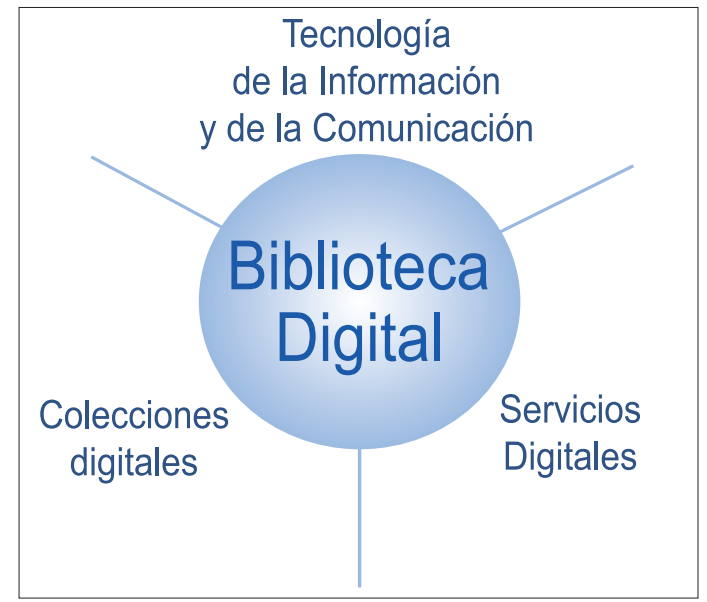

Figura 1. Componentes básicos de la Biblioteca Digital.

1 En el sentido de que no se fundamenta en este trabajo sino que se parte directamente de ella, debido a que se considera que ha sido suficientemente justificada y difundida a través de publicaciones y eventos académicos.

2 Para más detalles sobre la definición, $C f r$. Georgina Araceli Torres Vargas, Un modelo integral de biblioteca digital, México: UNAM, CUIB, 2008. 
Cada una de estas partes tendrá características propias del momento tecnológico actual, pues no hay que olvidar que la biblioteca en el medio digital experimenta cambios provocados por los vertiginosos avances en las Tecnologías de la Información y la Comunicación. Esto provoca que nos movamos constantemente de una imagen de biblioteca a otra, o que el modelo prevaleciente sea modificado debido a las características de las nuevas herramientas. Así, a esta biblioteca se le adjudican tantos nombres como usos tecnológicos que van apareciendo. Un ejemplo es de la Biblioteca 2.0 (también conocida como B2), que es un modelo que aprovecha las potencialidades de la Web 2.0. ${ }^{3}$

En opinión de Serrano, la B2 refleja a la participación como principal cualidad, ${ }^{4}$ y señala que tiene las siguientes características:

- Permite y fomenta la participación del usuario.

- Habla de compartir y no sólo de consultar o pedir en préstamo, de crear redes de usuarios, de comunicar y facilitar la comunicación entre usuarios y bibliotecarios y entre los propios usuarios.

- Socializa la recuperación y arquitectura de información, en un sistema escalable, permitiendo descentralizar la clasificación de los contenidos.

Otro modelo es el la Biblioteca Semántica, en la cual se reflejan las tendencias en el manejo de la información de la web 3.0. Ryszard $^{5}$ señala que la biblioteca digital semántica es la siguiente

3 Ramón Alberto Manso Rodríguez, Biblioteca 2.0; productos y servicios bibliotecarios en Internet, el camino a seguir, ponencia presentada en el evento Biblioteca XXI, Biblioteca Pública Rubén Martínez Villena, La Habana, Cuba, disponible en: http://www.bpvillena.ohc.cu/index.php?option=com_content\& task=category\&sectionid=9\&id=49\&Itemid=47 (consulta: 10 de junio de 2008).

4 Jorge Serrano Cobos, "Web 2.0 en las bibliotecas: el concepto de library 2.0", en: ThinkEpi, disponible en: http://www.thinkepi.net/2006/05/ (consulta: 11 de junio de 2008).

5 Sebastian Ryszard Kruk, "Goals of semantic digital libraries" (71-76), en: Sebastian Ryszard Kruk, Bill McDaniel (eds.), Semantic digital libraries, Berlin: Springer, 2009, p. 72. 
generación de biblioteca digital, la cual muestra los siguientes elementos:

- Integra información de diferentes tipos de metadatos.

- Ofrece interoperabilidad con otros sistemas (no sólo entre bibliotecas digitales), en un nivel de comunicación entre metadatos.

- Permite una búsqueda más robusta y amigable, gracias a los recursos semánticos.

El enriquecimiento de las tecnologías de la web semántica se refleja de forma más clara en el área de servicios de información. Morales del Castillo ${ }^{6}$ menciona que en la biblioteca digital las tecnologías de la web semántica se aplican para: desarrollar servicios de valor añadido; definir una descripción enriquecida; establecer ontologías que favorecen la interoperabilidad de los recursos; desarrollar interfaces de usuarios; mejorar la navegación; visualizar y presentar contenidos, entre otras cuestiones.

En el caso de la BIDEI se espera concretar una biblioteca digital semántica que descanse en estas tecnologías para la organización, la recuperación de información y el ofrecimiento de servicios, sin perder de vista que la biblioteca del medio digital es un ente que evoluciona de acuerdo con la tecnología que la sustenta, lo que a su vez determinará las características en los contenidos, en cuanto a sus usos, su organización y sus servicios. Por consiguiente, la BIDEI será una biblioteca en constante transformación, de acuerdo con aquellos usos tecnológicos que considere adecuados. Es decir, no se trata de adoptar toda la tecnología de la información y la comunicación que surja, sino que esto dependerá de las ventajas que aquélla ofrezca. También se consideran los siguientes elementos como parte de la Biblioteca Digital en Bibliotecología y Estudios de la Información.

6 José Manuel Morales del Castillo, Hacia la biblioteca digital semántica, Gijón: TREA, 2011, p. 80. 


\section{CARACTERÍSTICAS DE LA BIDEI}

Uno de los elementos esenciales de la biblioteca digital es la comunidad de usuarios a la que ésta se dirige, constituida por investigadores y profesores en bibliotecología, estudios de la información y áreas relacionadas.

En el caso de esta biblioteca, no sólo se considera al investigador como usuario sino también como productor de información digital, lo cual se articula perfectamente con el modelo de biblioteca digital 2.0. El trabajo en colaboración es otro rasgo distintivo de la B2, por lo que se espera que la BIDEI pueda ser un espacio propicio para esta actividad, la que se enmarca en lo que actualmente se conoce como la e-ciencia.

La e-ciencia se entiende como el conjunto de actividades científicas desarrolladas mediante el uso de recursos distribuidos, accesibles a través de Internet. ${ }^{7}$ Para Vallverdú, ${ }^{8}$ la e-ciencia no es simplemente ciencia clásica conectada a la red; más bien se refiere a nuevos modos de producir, administrar y analizar la información científica a través de formas de trabajo a distancia.

A partir de estas consideraciones existen diferentes aspectos que confluyen para integrar la biblioteca digital.

El aspecto social como eje

Pese a que el factor social es fundamental, la discusión acerca de la biblioteca digital se hace sobre aplicaciones tecnológicas específicas (bases de datos, documentos digitales, etcétera), así como los impactos de éstos en grupos sociales determinados (el uso de catálogos en línea, los portales bibliotecarios, etcétera), pero es poca la literatura que trata los aspectos sociales de la BD. Van

7 Libro blanco de la e-ciencia en España, Madrid: Fundación Española para la Ciencia y la Tecnología, 2005, p. 3.

8 Jordi Vallverdú, “Apuntes epistemológicos a la e-ciencia” (193-214), en Revista de filosofía, Vol. 64, (2008), p.195. 
House $^{9}$ muestra que hay una gran tendencia a evaluar los usos de las tecnologías que conforman a la $\mathrm{BD}$, sobre todo a través de los servicios, ya que la evaluación se ve como el medio idóneo para comprender el aspecto social de la biblioteca. Sin embargo, a pesar de la importancia de la evaluación, comprender las implicaciones de la biblioteca para la sociedad es un asunto que no sólo debe hacerse basado en la evaluación de que permita conocer si los servicios son los adecuados, sino que debe realizarse al conjunto de elementos que componen a la biblioteca digital en relación con su funcionamiento.

Para la BIDEI se tomarán como parámetro los aspectos que considera Saracevik ${ }^{10}$ en la categoría de evaluación de procesos; esto es, se evaluarán las herramientas, la representación de contenidos y los servicios, así como los usos de la biblioteca a partir de la percepción de los usuarios.

Más allá de la evaluación en la biblioteca digital, intervienen procesos sociales que, entre otras cuestiones, implican el análisis del contexto, de las políticas de información y de las organizaciones. ${ }^{11}$ De este modo, la BIDEI se estructura a partir de una serie de políticas de información y considerando a la biblioteca digital como una organización virtual.

\section{La BIDEI como organización virtual}

Una organización virtual es:

[...] un sistema de interrelaciones intensivas en conocimiento entre diversos agentes, que presentan objetivos complementarios, y que está soportado en las tecnologías de la información y de las comuni-

9 Nancy A. Van House, "Introduction: digital libraries as sociotechnical systems" (1-21), en: Ann Peterson Bishop (edit.), Digital library use: social practice in design and evaluation, Cambridge: MIT Press, 2003, p. 1.

10 Tefko Sarecevik, Evaluation of digital libraries: An overview, disponible en: http://comminfo.rutgers.edu/ tefko/DL_evaluation_Delos.pdf

\section{Ibídem.}


caciones, en el que cada uno aporta a la cadena de valor sus capacidades distintivas, con carácter temporal o permanente. ${ }^{12}$

La organización virtual supone varias características fundamentales:

1. La relación dinámica de diferentes organizaciones en la organización virtual, lo que en conjunto las presenta como una sola organización.

2. Distancia física entre las partes que la componen.

3. Capacidad para ofrecer productos personalizados. ${ }^{13}$

De acuerdo con García Muiña, ${ }^{14}$ una de las ventajas de las organizaciones virtuales es la capacidad que tienen para adaptarse rápidamente a las necesidades del entorno. Esta otra cualidad es esencial, sobre todo considerando el cambio constante en la biblioteca digital y que depende en gran medida del contexto tecnológico en que se desarrolla.

Entre los diferentes tipos de organización que mencionan los autores, la BIDEI se ubica en el modelo de estrella-satélite ${ }^{15}$ que se establece como una red que se interrelaciona a través de un agente principal o estrella que actúa como eje de la red, lo que delimita las funciones y los vínculos entre los participantes.

12 Fernando E. García Muiña, "Conceptualización y clasificación de las organizaciones virtuales: una aplicación en el caso español”, en Pymes online: información y negocio, disponible en: http://www.pymesonline.com/estaral-dia/articulos-y-documentos/detalle/po/conceptualizacion-y-clasificacionde-las-organizaciones-virtuales-una-aplicacion-en-el-caso-espa/poac/show/ Content/

13 Bob Travica, "Organizational aspects of the virtual library: a survey of academic libraries" (173-203), en: Library and Information Science Research: an International Journal, Vol. 21, Núm. 2 (1999), p. 180.

14 Fernando E. García Muiña, Ibídem.

15 Janice Burn, "Communicating for advantage in the virtual organization" (215-222), en: IEE transactions on professional communication, Vol. 42, Núm. 4 (dic., 1999), p. 217. 
La BIDEI será una organización virtual considerada como sistema sociotécnico, en el cual los procesos son reconfigurados a partir de la intervención de los distintos actores quienes le imprimen dirección e intencionalidad. Un ejemplo claro se observa en los procesos de catalogación.

En la actualidad hay una tendencia a cambiar la dinámica de los flujos de trabajo en el proceso de catalogación. A más de cinco décadas de catalogar, bajo los preceptos de las tradiciones bibliográficas, hoy existe una ruptura y se observa una gran fuerza entre las principales tendencias, las cuales están pensadas en el modelado a través de la computadora. Es así como la información con la que estamos familiarizados dispone de algoritmos automatizados y éstos, a su vez, disponen de representaciones de entrada y salida que están, de alguna manera, incorporadas a la estructura física de la computadora, lo que dirige a otras formas de organizar el trabajo, además de exigir nuevos conocimientos.

La tendencia a la intervención humana en el proceso de catalogación dirige hacia un cambio en la sistematización y organización del trabajo. Este proceso parte desde la estructuración de documentos digitales al momento de su edición.

Otro ejemplo es el proceso editorial de documentos digitales, que se muestra diferente de aquel que se relaciona con materiales impresos. En este escenario es donde aparecen las revistas y los libros electrónicos, así como la creación de documentos en red, y donde tanto los actores como los procesos están cambiando. Esto afecta directamente el desarrollo de las colecciones digitales, así como en los servicios que presta la biblioteca digital.

Desde una visión social y con base en los aspectos hasta aquí mencionados, se han delimitado las siguientes pautas para el diseño de la biblioteca Digital en Bibliotecología y Estudios de la Información. 


\section{PAUTAS PARA EL DISEÑO DE LA BIDEI}

\section{Colección}

Para la colección digital inicial, se hacen las siguientes consideraciones:

- Todos los documentos incluidos en la colección de la Biblioteca Digital serán digitales de origen.

- Las revistas con una suscripción digital ya realizadas por la biblioteca no se consideran parte de esta colección. Sin embargo, se ofrecerán los enlaces al catálogo de estas revistas.

- Los documentos digitales generados por la comunidad de investigadores y alumnos del doctorado en Bibliotecología y Estudios de la Información y de las instituciones colaboradoras en el proyecto, se incluirán en la colección de esta biblioteca.

Los documentos digitales serán los siguientes:

- Monografías editadas por el IIBI.

- Carteles publicitarios de eventos académicos del IIBI.

- Vídeos digitales de conferencias, simposios o coloquios.

- Entrevistas a investigadores y colegas que realizan estancias y trabajo en colaboración con los investigadores del IIBI.

\section{Tecnologías}

Entre los elementos relacionados con el apoyo para el desempeño de la e-ciencia en el contexto de la bibliotecología y estudios de la información, se puede mencionar la creación de un repositorio que complemente los recursos contenidos en la biblioteca digital.

Se considera la inclusión de un repositorio dentro de la Biblioteca Digital, por lo que los documentos relativos a los avances de investigación o aquellos que se generan en el trabajo de colaboración, se recolectan a través de seminarios, proyectos colectivos 
nacionales y/o internacionales. Otros materiales serán los avances de las tesis doctorales, que el estudiante compartirá con su tutor y cotutores.

Los fines del repositorio que formará parte de la biblioteca digital serán los siguientes:

1. Establecer una comunicación y colaboración académica.

2. Favorecer la publicación digital de los resultados preliminares de investigación. Esta información debe ser protegida con un acceso restringido tanto para el autoarchivo como para el uso y consulta de tales materiales.

El repositorio deberá ser un sistema que facilite la recolección y almacenamiento de los resultados de investigación de los investigadores, así como los diferentes contenidos académicos creados por alumnos del posgrado.

Por otro lado, sobre la base de una evaluación del software disponible para la construcción de bibliotecas digitales con rasgos semánticos, se decidió utilizar el Extensible Catalog (xc), que es un software de código abierto. El esquema de metadatos de XC está basado en RDA (Resource, Description and Access) y en FRBR (Functional Requirements for Bibliographic Records). Dado que el esquema de metadatos propio de xc ya está preparado para presentar los datos en RDA, permite la creación de una Biblioteca Digital Semántica.

Otra herramienta que se utilizará será el sistema de Onix para hacer el etiquetado. Este programa utiliza el lenguaje XML, que es ampliamente utilizado para intercambiar datos o para compartir entre varias aplicaciones y plataformas. Consideramos que el uso de XML proporciona muchas ventajas, como la flexibilidad de la presentación y el potencial de transferir información a otros sistemas. 


\section{Servicios}

Como se mencionó, los servicios de la Biblioteca Digital en Bibliotecología y Estudios de la Información tienen una relación directa con el ciclo de publicación digital, por lo que como parte de los servicios se contemplan los medios tecnológicos necesarios para la autopublicación y el etiquetado de documentos digitales por parte de los autores. Junto con esto, se consideran también los siguientes servicios:

- Servicios de control de calidad que verifican la calidad de los metadatos en la publicación, aspecto que es determinante en la búsqueda semántica y la recuperación.

- Búsqueda, exploración, aplicación y recomendación de recursos entre los usuarios, o por la biblioteca, a través de las redes sociales.

- Diseminación y notificación servicios. Really Simple Syndication (RSS) y servicios de notificación por medios electrónicos. También se incluyen los servicios móviles de información.

- Igualmente se incluirán servicios a través de Wikis y Blogs, entre otros recursos propios de la web 2.0.

- Otro servicio es el ofrecimiento de software para el trabajo en red, así como otros recursos para la creación de documentos digitales y la sistematización electrónica de referencias bibliográficas.

- La comunicación a través de redes sociales. Las redes sociales permiten la comunicación entre los usuarios y su biblioteca.

\section{Organización de contenidos}

A la fecha se cuenta con los lineamientos para la descripción de una categoría de la colección de la biblioteca digital: las imágenes visuales. Esto se realizó considerando que, debido al rápido crecimiento de colecciones digitales, han aparecido diferentes es- 
quemas de metadatos, cada uno de los cuales responde a necesidades particulares de acuerdo con los tipos de materiales, los ámbitos temáticos, las necesidades de las comunidades de usuarios, etcétera. Es por eso que el método estándar o uniforme no es factible en muchas de estas ocasiones. Además, las colecciones de imágenes son tan diversas como la disposición de metodologías para su organización; no hay un enfoque que sea el rector en todos los casos, pues archivos, bibliotecas, museos y otras instituciones tienen diferentes tradiciones y normas para hacerle frente a estas colecciones.

\section{NATURALEZA Y PROPÓSITO DE LA COLECCIÓN}

La descripción bibliográfica es una actividad que conlleva la interpretación, uso y aplicación de diversos principios, normas y estándares. De ahí que sea necesario encontrar los mecanismos apropiados que ofrezcan alternativas a la solución de tres problemas básicos:

1. La creación de lineamientos para normar y unificar la información bibliográfica.

2. La propuesta de prácticas recomendables para el conjunto de actividades del proceso de catalogación.

3. La propuesta de los instrumentos metodológicos que permitan planear, implementar y usar la información de las bases de datos.

De los tres problemas anteriores, el que nos interesa destacar en este documento es el primero, puesto que ahí es donde el proceso de catalogación basa su control de calidad. Es decir, sabemos que en las diversas comunidades científicas existe un universo de posibilidades para crear los registros descriptivos de sus documentos, pero los avances logrados en la actividad de los metadatos, la creación de modelos conceptuales para analizar da- 
tos e información contenida en las bases de datos, la constitución de diversos programas computacionales para crear repositorios, entre otras cuestiones, constituyen algunos de los tantos beneficios que les dan fortaleza a los sistemas de información actuales.

Para la constitución de estos lineamientos fue necesario atender en principio las siguientes interrogantes: ¿qué es lo que se catalogará?, ¿cómo se tratará la relación obra-manifestación? Estos planteamientos nos ofrecen una acotación sobre la manera en que se ve al documento objeto de catalogación (en este caso a la fotografía), de forma que se logre elegir la alternativa en la forma de descripción que más se ajusta a dicho documento, entre la multiplicidad de opciones existentes.

En la constitución de una base de datos para el registro de documentos fotográficos, se deberán vincular los registros de la obra (representación visual o contenido), con los datos o información del continente. Esta lógica obedece a la catalogación de imágenes de obras complejas, o lo que se conoce como obras en partes múltiples, donde hay una obra (la cual en este caso se registra visualmente en un documento), que a su vez representa parte de una obra.

Para establecer tanto los niveles de descripción de la obra como de sus manifestaciones, los lineamientos que se ofrecen responden a la utilización de dos herramientas: los códigos de catalogación y los estándares de metadatos.

\section{CÓdigos DE CATALOGACIÓN}

La catalogación es el proceso de identificar y localizar un documento por medio del establecimiento de los puntos de acceso (autorías, títulos, temas). El resultado es el asiento bibliográfico o catalográfico. Para ello se requiere que el proceso de catalogación responda a ciertos principios de uniformidad, unificación e identificación establecidos en los códigos de catalogación. Un 
código de catalogación es un conjunto de principios básicos y reglas estructurados que auxilian al catalogador en su tarea.

Entre los códigos de catalogación que existen, se eligió el CCO (Cataloging Cultural Objects), puesto que éste se apega a los requerimientos para la catalogación de la fotografía, al ofrecer elementos para la descripción de imágenes.

Otro código elegido es el RDA (Resource, Description and Access), que es un estándar de contenido (no de presentación) de los registros que conforman el catálogo. Su estructura permite y favorece la descripción de todo tipo de recursos, incluyendo los analógicos y los digitales, y facilita la cobertura de todo tipo de formatos y contenidos.

El código RDA es adecuado en tanto que proporciona un marco flexible para la descripción de recursos digitales y facilita la aplicación con esquemas de metadatos, como el del Núcleo de Dublín (Dublin Core); las descripciones que resultan del empleo del código de RDA pueden usarse en ambientes digitales, catálogos en la web y servicios de localización de recursos.

\section{ESTÁNDARES DE METADATOS}

Los metadatos tienen como objetivo describir un documento en una colección, proveer de múltiples vías para obtenerlo y poner su contenido en el contexto digital. Los metadatos buscan facilitar el funcionamiento y la capacidad de compartir los datos entre los buscadores, así como elevar su precisión, para hacer más efectivo el proceso de búsqueda y recuperación en la Web y, de esta manera, permitir a los usuarios conocer los datos sobre los recursos que necesitan. Los metadatos son datos más o menos estructurados sobre datos, los cuales no se colocan en una ficha como los datos catalográficos, sino que se almacenan en una base de datos con una referencia al texto completo o se incluyen mediante metaetiquetas, de manera que puedan recuperarse los documentos. Los metadatos tienen tres funciones: 
- Proporcionar una descripción de una entidad de información junto con otra información necesaria para su manejo y preservación.

- Proporcionar los puntos de acceso a esa descripción.

- Codificar esa descripción.

En el entendido de estas funciones, se eligieron diferentes estándares que, en conjunción con los códigos de catalogación antes mencionados, dieran como resultado la descripción de fotografías.

Los estándares utilizados son: Categories for the Description of Works of Art (CDWA), el VRA (Visual Resources Association), Core 4.0, el PMDO (Preservation Metadata for Digital Objects) y el METS (Metadata Encoding Transmission Standard).

En todo estándar de metadatos se distinguen tres categorías de acuerdo con la función que desempeñan y con la información que ofrecen. Tales categorías son:

a) Metadatos descriptivos: su objetivo es la descripción e identificación de los recursos de información, sea en un sistema local para permitir la búsqueda y recuperación de una determinada categoría de documentos o imágenes (ejemplo: fotografías de automóviles), o bien, en aplicación web para facilitar a los usuarios la localización de recursos.

b) Metadatos técnicos: facilitan la navegación y presentación de los recursos electrónicos proporcionando información sobre la estructura interna de los mismos (página, sección, capítulo, numeración, índices, tablas de contenidos); la relación entre los materiales (fotografía B incluida en el manuscrito A), y unen los archivos de imagen y textos relacionados (archivo A es el formato JPEG de la imagen del archivo).

c) Metadatos administrativos: facilitan la gestión y procesamiento de las colecciones digitales tanto a corto como a largo plazo, incluyendo los datos técnicos sobre la creación y el con- 
trol de calidad, la gestión de derechos, el control de acceso y utilización, y las condiciones de preservación (ciclos de actualización, migración, etcétera).

Para el propósito de preservación digital, puede considerarse cualquiera de las categorías mencionadas; por tanto, los metadatos de preservación (recordkeeping metadata) no son tanto una categoría separada de metadatos como la suma de varios tipos.

De hecho, la definición de metadatos suele presentarse combinada; es decir, no se separan bajo las categorías señaladas, ya que lo que se pretende es que el etiquetado ofrezca elementos complementarios. Estas categorías son importantes en el proceso de elección del etiquetado, mas no en su presentación o visualización.

Una vez definido el etiquetado completo para el recurso o documento digital, es necesario que quienes se ocupen del desarrollo del sistema de recuperación y visualización final de la información, consideren los metadatos en dos categorías: metadatos intrínsecos o implícitos y metadatos explícitos o extrínsecos.

\section{METADATOS INTRÍNSECOS O IMPLÍCITOS}

La mayoría de los metadatos implícitos son, generalmente, de mayor uso para aquellos que administran la colección más que los que la usan.

Mientras que la mayoría de los metadatos implícitos son derivados del fichero en sí mismo, una cierta cantidad podría, también, ser derivada de su contexto (por ejemplo, su localización dentro de los directorios o carpetas o sobre servidores). Al desarrollar una colección digital, podría ser de utilidad extraer algunos metadatos implícitos y almacenarlos separadamente dentro de una base de datos para propósitos de recuperación, control de calidad o preservación digital. 


\section{METADATOS EXPLÍ́CITOS O EXTRÍNSECOS}

Por lo general, son los más importantes para el usuario final. Aquellos que desarrollen colecciones digitales necesitarán tomar decisiones sobre cuáles metadatos implícitos deberían ser extraídos, y cuáles metadatos explícitos se necesitan para ser reunidos o creados para apoyar a la colección y a sus usuarios.

Las etiquetas asignadas de acuerdo con los estándares de metadatos corresponden a:

Registro de la obra. Se refiere a la representación visual que contiene la fotografía.

Registro de la imagen impresa. Ofrece datos de autoría, características físicas, entre otros datos, relacionados con la fotografía impresa u original.

Registro de la autoría. Son datos asociados a las autorías de obra (nombres preferidos y variantes del nombre de autores personales y/o corporativos).

Estos rubros se ofrecen en dos versiones:

1. Registro bibliográfico con descripción completa. Es aquel en el cual se muestra el etiquetado general recomendado para cada registro, en el entendido de que no todas las etiquetas habrán de ser visualizadas en el sistema que se elija, pero servirán para interoperar con otros sistemas que registren documentos fotográficos. El registro bibliográfico completo es útil en el intercambio de datos y, por ende, de recursos de información fotográficos.

2. Registro bibliográfico con descripción mínima. Este registro atiende los elementos que obligatoriamente deberán contemplarse en la descripción de la fotografía. Pueden utilizarse también como elementos mínimos de visualización o de despliegue de la información. 
Biblioteca Digital Académica en Bibliotecología...

De manera general, se han descrito los elementos de los que habrá de constar la BIDEI. Dichos componentes se delimitaron en la primera fase del proyecto. 


\title{
Políticas de informação para bibliotecas digitais: conceitos e componentes
}

\author{
ANA LÚCIA TERRA \\ Instituto Politécnico do Porto, Portugal
}

\section{INTRODUÇÃO}

$\mathbf{N}$ uma reflexão sobre o tema das políticas de informação nas bibliotecas digitais, torna-se fundamental um esclarecimento prévio do conceito operatório, de modo a evitar equívocos derivados da superficialidade terminológica e conceptual. Estes aspetos terão necessariamente influência sobre o âmbito de aplicação e sobre o conteúdo da expressão "políticas de informação". Assim, para uma abordagem mais profícua sobre um domínio micro das políticas de informação, no caso específico da biblioteca digital, importa considerar o contexto mais geral das políticas de informação, numa breve resenha do seu percurso evolutivo, na sua configuração enquanto campo de estudo e âmbito de ação.

É neste cenário teórico macro que se inscreve e de onde derivam as políticas de informação formuladas e/ou praticadas nas bibliotecas digitais. De seguida, iremos procurar identificar e analisar a posição de alguns autores a propósito deste conceito operatório, expondo a nossa proposta do que devem ser os elementos constituintes do universo da política da informação da biblioteca digital e as suas componentes de acordo com um modelo processual, de índole sociotécnica. 


\section{BREVE ABORDAGEM DIACRÓNICA ÀS POLÍTICAS DE INFORMAÇÃO}

No ocidente, o período do pós II Guerra Mundial marca o início da definição formal de políticas de informação nacionais na medida em que o acesso à informação científica e tecnológica passa a ocupar um lugar central no desenvolvimento económico, sendo um pilar da inovação e condição para a competitividade. Este movimento iniciático encontra o seu vértice num documento conhecido como Relatório Weinberg, mas intitulado Science, government, and information: the responsibilities of the technical community and the government in the transfer of information, tendo como relator Alvin M. Weinberg, diretor do Oak Ridge National Laboratory nos EUA. Neste texto, reação americana à posição de vantagem demonstrada pela uRss com o lançamento do Sptunik (1957), sublinha-se o perigo que o crescimento exponencial da informação podia representar para a ciência, cabendo ao governo, aos profissionais da informação e à comunidade científica a responsabilidade pela transferência da informação científica e técnica. Deveremos notar que no Relatório Weinberg é sempre utilizada a expressão informação, pois é com ela que o cientista trabalha e não com o documento. A este propósito, pode ler-se:

[...] the basic problem of literature access can be considered a switching problem - switching information, not documents. The basic need is to connect each customer, as nearly as possible, to the information he needs [...] (United States. President's Science Advisory Committee, 1963, p. 30).

O modelo de política de informação científica e técnica proposto por Weinberg foi adotado e adaptado em vários países e instituições internacionais, com especial relevo para a UNESCO. Promoviam-se os serviços de informação através da criação de uma estrutura burocrática, incluindo serviços descentralizados e coordenados por um órgão de tutela, visando a configuração de um sistema em rede, e programas de execução específicos. 
Apesar deste papel pioneiro do Ocidente, não deveremos esquecer que, a partir de meados da década de trinta, do século xx, Shiyali Ramamrita Ranganathan, já trabalhava na conceção e implementação de uma política nacional de informação na Índia (Grolier, 1993). De facto, este autor, a par de um trabalho inovador em bibliotecas universitárias e de uma reflexão teórica para fundamentar a Biblioteconomia em bases científicas, concebeu um sistema bibliotecário nacional para a Índia alicerçado nas bibliotecas públicas, urbanas e rurais, e numa biblioteca central nacional, mas incluindo também bibliotecas regionais que ocupariam o lugar intermédio num sistema hierárquico. Este sistema modelo inspirava-se e procurava dar cumprimento às cinco leis da Biblioteconomia formuladas pelo mestre indiano: os livros existem para serem lidos; a cada leitor o seu livro; a cada livro o seu leitor; poupar tempo ao leitor e a biblioteca é um organismo em crescimento. Em 1950, as suas orientações, apresentadas como uma lei modelo para as bibliotecas da Índia, foram publicadas pela universidade de Delhi com o sugestivo título Library development plan: thirty years programme for India, indicando tratar-se de um plano de longo alcance em termos temporais. Em 1964, Ranganathan editou uma versão atualizada deste plano com projeções até à década de oitenta.

No Ocidente, desde a década de sessenta até à atualidade, o âmbito de intervenção das políticas de informação foi-se alargando progressivamente (Figura 1). Assim, nas décadas de sessenta/ setenta, a política de informação centra-se, essencialmente, nas questões relacionadas com a difusão da informação científica e tecnológica. Já nos anos oitenta, foi orientada para a implementação da infraestrutura de informação, assente nas telecomunicações. Na década seguinte, a preocupação incide, sobretudo, nos desafios da adaptação ao novo contexto da Sociedade da Informação. Portanto, o campo de intervenção das políticas de informação foi sendo ampliado porque a sua restrição aos recursos e unidades de informação, como arquivos, bibliotecas e centros de documentação, deixou de ser adequada num contexto onde a criação, difusão e transformação da informação passou a ser for- 
temente dominado pela tecnologia. Tornou-se evidente que cada país necessitava de uma nova abordagem ideológico-estratégica para as políticas de informação.

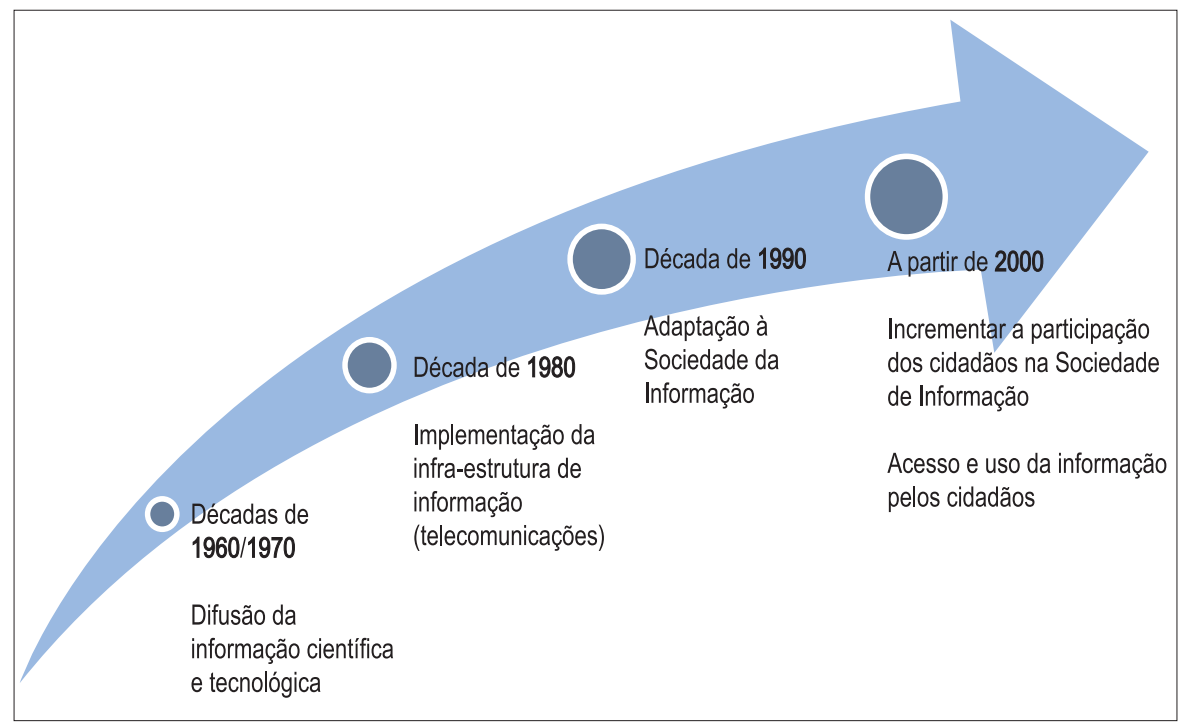

Figura 1.

Ampliação do âmbito de ação das políticas de informação

Segundo Moore (1997), na Sociedade da Informação, a abordagem às políticas de informação apresenta uma grande similitude em termos de objetivos, apesar de os mecanismos de cada Estado para os concretizar poderem diferir substancialmente. $\mathrm{O}$ primeiro objetivo diz respeito à criação de uma infraestrutura de telecomunicações eficiente para a comunicação dos indivíduos e das organizações. A meta será transformar essa rede num serviço universal capaz de lidar com quantidades cada vez maiores de informação digital. O segundo objetivo prende-se com a promoção da competitividade e da produtividade industrial e comercial através da utilização da informação enquanto recurso, retomando a perspetiva formulada nos anos sessenta e setenta acerca da importância da informação para o progresso global. Os ganhos de produtividade poderão decorrer de vários fatores, tais como uma 
melhor aplicação da investigação para acelerar a inovação, através da informatização de processos administrativos ou através da aplicação de técnicas de gestão da informação. No entanto, para concretizar este objetivo é necessário preencher um pré-requisito que constitui, também, o terceiro objetivo das políticas de informação na Sociedade da Informação. Trata-se da necessidade de todos os indivíduos possuírem competências tecnológicas e informacionais, remetendo para a área da educação e da formação. Além disso, considera-se que a Sociedade da Informação tende a favorecer a harmonia e a coesão social. Por outro lado, as políticas de informação na Sociedade da Informação, através de infraestruturas de comunicação cada vez mais poderosas, permitirão um maior nível de informação e de participação democrática. Mas, para além deste objetivo político, deveremos, igualmente, atender a aspetos de ordem cultural, valorizando e reforçando a cultura nacional de cada país em termos internos, bem como do ponto de vista externo.

Assim, atualmente, um dos objetivos da política de informação é o desenvolvimento do sector tecnológico, em particular das tecnologias de comunicação, de telecomunicação e da informática para criar uma infraestrutura de informação considerada um motor de progresso económico e social. Neste cenário, a Internet torna-se a materialização mais visível dessa convergência e constitui, portanto, uma nova componente das políticas de informação. Mas importa novamente não esquecer que, nas economias baseadas na informação e no uso intensivo da Internet, a competitividade deriva, num grau elevado, das competências informacionais dos indivíduos, o que remete para aspetos educacionais, incluindo de literacia da informação.

Em suma, no contexto da atual Sociedade da Informação, a formulação de uma política de informação deve ter em conta quatro princípios centrais e complementares: o acesso universal, o livre acesso às redes de informação, a igualdade de oportunidades para todos os cidadãos e o respeito pela diversidade cultural e linguística na criação de conteúdos. 
Portanto, verificamos que historicamente as políticas de informação alargaram o seu âmbito de incidência. Inicialmente, centraram-se na criação de sistemas de informação baseados em bibliotecas e arquivos. Todavia, com a progressiva aplicação das tecnologias informáticas ao tratamento da informação, passaram também a abranger os aspetos relacionados com as TIC. Esta evolução coincide, aliás, com a definição de Ciência da Informação, formulada por Silva e Ribeiro, no âmago da qual encontramos a Biblioteconomia/Documentação, a Arquivística e os Sistemas Tecnológicos de Informação, e que tem por objeto a informação, definida nestes termos: "[...] conjunto estruturado de representações mentais e emocionais codificadas (signos e símbolos) e modeladas com/pela interação social, passíveis de serem registadas em qualquer suporte material [...] e, portanto, comunicadas de forma assíncrona e multidireccionada." (Silva, 2006, p. 150)

A informação apresenta-se como fenómeno - dado, facto, referência (conjunto lato de representações) - e como processo - produz-se, memoriza-se e recupera-se dinamicamente. Mas o objeto da Ciência da Informação pode e deve ser alargado ao "fenómeno info-comunicacional". Ora, isso significa o alargamento ou pelo menos uma ênfase mais pronunciada nos aspetos relacionados com o acesso e o uso dos sujeitos que utilizam a informação e que a comunicam, transformando-a e transmitindo-a.

Esta representação epistemológica da informação como fenómeno e processo gerado, transformado, difundido e transferido por diferentes suportes e modelos tecnológicos, implica que a informação precede e "substancializa" o documento. Sublinhe-se que tal premissa não é inócua para a definição de política de informação. De facto, significa a transição de políticas de documentação, centradas na conservação dos suportes, de documentos, para políticas de informação vocacionadas para o acesso. Simultaneamente, o realce dado ao fenómeno info-comunicacional é particularmente importante para a análise da política de informação para as bibliotecas digitais, na medida em que o facilitar a difusão e o acesso à informação constituem premissas básicas destes sistemas de informação complexos. 


\section{AS POLÍTICAS DE INFORMAÇÃO ENQUANTO CAMPO DE ESTUDO}

As políticas de informação apresentam características atípicas das outras áreas de intervenção política, como a educação ou a saúde. De facto, trata-se de uma área de intervenção política recente que não encontra eco nas reflexões dos analistas políticos tradicionais. Além disso, envolve interesses de grupos muito vastos e díspares, pelo que as medidas tomadas no campo da informação podem ter um impacto determinante noutras áreas, como, por exemplo, na investigação, na segurança ou nas questões de cidadania. Paralelamente, as políticas de informação também são influenciadas por decisões políticas noutros campos e por opções de índole não política, como o comportamento informacional dos indivíduos, as estratégias de marketing dos editores ou as escolhas das tecnologias de comunicação (Braman, 1990, p. 48-51). A este propósito, Rowlands (2003) considera que uma das características mais interessantes das políticas de informação é que elas são simultaneamente moldadas pelo mundo exterior e moldam esse mesmo mundo. Apresentam-se como uma variável dependente e independente, em áreas muito díspares.

Apesar desta constatação, alguns autores optam por focalizar as políticas de informação num campo único. Arnold (2004), ao tratar da importância das políticas de informação para os países em desenvolvimento, centra a sua atenção exclusivamente nos aspetos económicos. Outros autores, como Orna (1999) ou Karni (1983), optam por tratar as políticas de informação numa abordagem organizacional.

Esta pluralidade sustenta a visão muito crítica de Browne (1997a, p. 270) relativamente à definição do âmbito das políticas de informação, enquanto campo de estudo, afirmando que "[...] there is a feeling of discomfiture in a field in which researchers are unable to even broadly indicate the substance of what it is they desire to study". Mas também Kajberg e Kristiansson (1996, p. 5) partilham esta opinião sintetizando-a de forma muito clara: 
"There is an evident lack of consensus of what constitutes the core of information policy [...] what is missing is a coherent theoretical framework".

No entanto, do nosso ponto de vista, apesar de as políticas de informação se apresentarem como uma área de intervenção e de estudo muito vasta, é indiscutível a sua existência enquanto tal. Afigura-se-nos, por isso, ser mais proveitoso considerar as políticas de informação como uma área específica de reflexão e de ação, importando refletir sobre o seu âmbito a partir das propostas de alguns autores.

\section{AlguMAS PROPOSTAS SOBRE O ÂMBITO DAS POLÍTICAS DE INFORMAÇÃO}

Numa abordagem marcadamente pragmática, Wesley-Tanaskovíc (1985), Atherton (1977) e Montviloff (1990) entendem que criação de um sistema de informação constitui o âmago das políticas de informação. Estes autores, que trabalharam sob a égide da UNESCO, desenvolveram investigação e publicaram manuais para a conceção e implementação de sistemas nacionais de informação, base para a estruturação de um sistema mundial. De acordo com Montviloff (1990), as políticas de informação constituem orientações destinadas a conceber uma estratégia e formular programas de desenvolvimento e de utilização dos recursos, dos serviços e dos sistemas de informação, incluindo nesta designação apenas as unidades documentais tradicionais (bibliotecas, centros de documentação e arquivos), com recurso aos sistemas tecnológicos. Estas políticas são formuladas através de "instrumentos de intervenção", agrupados em três categorias: instrumentos jurídicos (constituições, leis, regulamentos, tratados internacionais, entre outros), instrumentos profissionais (códigos de conduta, códigos deontológicos, reflexões, etc.) e instrumentos culturais (costumes, tradições ou valores sociais). Teremos micropolíticas, se forem relativas a um organismo ou a uma instituição, e macropolíticas, se 
o contexto de aplicação for nacional, regional ou internacional. Mas, em qualquer dos níveis, o enfoque vai para o acesso à informação que deve servir todos os intervenientes do sistema económico e social, disponibilizando informação atualizada, pertinente e fiável, apresentada como condição para o progresso.

O âmbito das políticas de informação diz respeito à coordenação de componentes relacionadas com a informação e que geralmente carecem de uma abordagem global em termos nacionais. Todos os trabalhos realizados sob a égide da UNESCO estavam orientados para a criação de um supersistema em rede de informação mundial, de apoio à investigação científica e tecnológica, como base para o desenvolvimento económico e social de todos os países, mas em particular dos países em vias de desenvolvimento. Não poderemos deixar de notar alguma similitude entre este intento e a visão de Paul Otlet para a criação de um sistema mundial de informação, sobretudo se recordarmos os programas de Controlo Bibliográfico Universal e de Acesso Universal aos Documentos promovidos pela UNESCO.

Numa abordagem distinta, outros autores sublinham o âmbito sociotécnico das políticas de informação. Maxwell (2003) apresenta-as como "[...] social, political, legal, economic and technological decisions about the role of information in society. These decisions operate both at societal level when applied to national and international policy, and at an instrumental level as they impact the creation, dissemination, use and preservation of information". Esta definição procura sintetizar a complexidade inerente às políticas de informação, enfatizando a diversidade de formas que as podem materializar, desde preceitos constitucionais, leis governamentais ou jurisprudência aplicáveis a campos tão diversos como o comércio, a implementação e o uso de tecnologias ou opções para a criação e acesso à informação. Por outro lado, as políticas de informação envolvem uma multiplicidade de atores, com preocupações e interesses muito díspares, e apresentam uma natureza sociotécnica evidente, implicando um relacionamento dinâmico entre os atores sociais e os aspetos instrumentais como as tecnologias. 
As teorias cognitivas e sociocognitivas da Ciência da Informação poderão dar um contributo útil para aprofundar as vertentes humanas e sociais inerentes à política de informação. Esta conceção é particularmente relevante numa sociedade onde os indivíduos são chamados a terem cada vez mais obrigações e direitos e, por isso, necessitam de estar devidamente informados. Sem um acesso adequado à informação, os sujeitos não estarão habilitados a desempenhar na plenitude o seu papel de cidadãos, não podendo igualmente aproveitar todas as vantagens que essa cidadania lhes pode oferecer. A componente tecnológica no âmbito das políticas de informação deve ser repensada atendendo a que o recurso crítico é a informação e não a estrutura tecnológica que é utilizada para a manipular. Naturalmente, ao atender aos aspetos sociais, será importante examinar as necessidades individuais e as da sociedade no seu geral, de maneira a que as políticas de informação respondam a ambas as vertentes de forma equilibrada. Não deveremos esquecer que essas necessidades são variadas, existindo frequentemente conflitos entre elas. Assim, por exemplo, poderão ocorrer conflitos entre o desejo de certos sectores para promoverem um acesso sem restrições à informação e a pretensão de outros grupos de limitar esse acesso a fim de salvaguardar direitos de autor ou para proteger a segurança nacional. A política de informação deverá entender estas preocupações, necessidades e interesses, equilibrando-os de forma razoável.

Em alguns países, sobretudo durante os anos oitenta, as políticas de informação ficaram circunscritas à criação de uma infraestrutura de telecomunicações. De qualquer forma, a política de informação e a infraestrutura telecomunicações são interdependentes. Uma boa infraestrutura nacional de telecomunicações pode ajudar a promover a criação de uma política de informação. Inversamente, também é verdade que a formulação de uma política de informação pode constituir uma base sólida para a criação de uma infraestrutura nacional de telecomunicações adequada. A componente tecnológica está tão imbricada nas políticas de informação que é difícil ou mesmo desnecessário estabelecer uma 
fronteira estanque entre a política tecnológica e a política de informação. Assim, naturalmente, ambas as vertentes deverão ser analisadas na sua globalidade conjunta. De facto, num contexto de crescimento exponencial da informação, a política de informação não pode ignorar a tecnologia que suporta a criação, o tratamento e a recuperação da sua matéria-prima.

A atenção aos aspetos sociais e aos indivíduos é fundamental no contexto da Sociedade da Informação, pois é através da utilização pessoal de cada um que a informação se multiplica. Neste sentido, convém assegurar a inserção de todos cidadãos na Sociedade da Informação, nomeadamente através da inclusão digital, na vertente cognitiva e tecnológica. Por outro lado, a informação afeta as relações sociais de duas formas inquestionáveis. Por um lado, a informação serve de mediador nas relações interpessoais, pois é com base nela que se estabelecem relações entre os indivíduos ou entre as organizações. Além disso, mudanças na posse da informação ou nos seus canais de circulação podem modificar as relações entre as pessoas ou as instituições, os governos ou as nações.

Ao atender aos aspetos sociotécnicos, deveremos também realçar que o próprio contexto social, político e económico condicionam a formulação ou até a inexistência de políticas de informação. Aliás, como é natural, cada país aborda a política de informação nacional com base na sua própria tradição cultural, legal, de acordo com a sua estrutura social, económica e política e consoante as influências externas que recebe e a forma como as assimila. Como notou Morales (1999) a propósito da realidade Mexicana, "The information policies we will establish will be closely related to the general policies of each country, with public policies pertaining to education and cultures, and the historical and the social realities of the nation itself [...]".

Já Overman e Cahill (1990) consideram que o âmbito das políticas de informação abrange uma estrutura normativa que obedece a dois tipos de perspetivas, as restritivas e as distributivas, dentro das quais se distribuem sete valores: o acesso e a liberdade, a privacidade, a abertura, a utilidade, o equilíbrio custo-benefício, o segredo e a segurança, além da propriedade intelectual. 
As questões do acesso e da liberdade são inerentes ao bom funcionamento da democracia porque os cidadãos necessitam de estar bem informados. No entanto, os direitos de acesso, plasmados na legislação de muitos países, sofrem tensões consideráveis, devido à necessidade de compatibilizar as vertentes da segurança e da liberdade de acesso à informação. A privacidade é um dos valores comuns aceites pelas sociedades democráticas, apesar de também haver incompatibilidades entre as necessidades de informação do governo e da sociedade e o direito individual de cada cidadão à salvaguarda da sua privacidade. Já a abertura diz respeito ao direito dos cidadãos de tomarem conhecimento dos processos de decisão do governo. Por seu lado, a utilidade refere-se à informação coletada pelo Estado para servir fins específicos, os quais devem determinar o que é recolhido e conservado. $\mathrm{O}$ equilíbrio custo-benefício assume que a informação tem um valor económico o que pode levantar problemas na coordenação entre o interesse público e os interesses comerciais, nomeadamente quanto à informação na posse do Estado. O segredo e a segurança constituem dois valores centrais, sobretudo quanto à informação do Estado. Por fim, a propriedade intelectual e o respeito pelos direitos dela derivados constitui outro valor fundamental que também coloca em questão o equilíbrio entre os interesses individuais e da sociedade e os interesses comerciais.

Partindo de uma análise bibliométrica da produção científica relativa às políticas de informação, Rowlands desenvolveu uma reflexão consistente e numerosa sobre este campo. Nos seus últimos textos sobre a matéria (Rowlands, 2003a, 2003b), considera tratar-se de uma área temática e de intervenção complexa, que deve ser abordada com um elevado grau de abrangência e numa perspetiva de inclusão. Em termos de âmbito, defende que as políticas de informação envolvem nove grandes tópicos: políticas e práticas governamentais sobre a gestão de recursos de informação, políticas de telecomunicações e de radiodifusão, políticas internacionais de comunicação, políticas de difusão da informação, confidencialidade e privacidade da informação, regulação e criminalidade informática, propriedade intelectual, política bibliote- 
conómica e arquivística bem como disseminação da informação da administração pública. De modo a tornar mais inteligível a área, Rowlands delineou um modelo para categorizar as políticas de informação estruturado em dois eixos (abertura vs controlo e regulação dos mercados vs controlo do Estado) por onde se distribuem cinco clusters (A. proteção da informação, B. mercados da informação, C. radiodifusão e telecomunicações, D. acessibilidade à informação governamental, E. sociedade e infraestrutura da informação). Aplicando este modelo, a análise dos valores, da ética e do contexto legal regulador das políticas de informação será mais esclarecedora.

Pelos parágrafos anteriores, fica patente que existe uma produção literária abundante sobre o tema das políticas de informação. No entanto, apesar desta abundância em termos editoriais há a necessidade reflexões consistentes sobre os fundamentos teóricos, o âmago e a construção das políticas de informação. Trata-se de um trabalho em desenvolvimento que pode ser concretizado em contextos diversos. De seguida e depois desta digressão conceptual e teórica, procura-se refletir sobre as políticas de informação para a realidade específicas das bibliotecas digitais.

\section{POLÍTICA DE INFORMAÇÃO NA BIBLIOTECA DIGITAL}

\section{Introdução ao uso do conceito}

Apesar da abundante literatura sobre bibliotecas digitais, com as mais variadas origens em termos de áreas de estudo, e quer digam respeito a análises teóricas ou a casos práticos, a temática específica da política de informação não é tratada aprofundadamente, nem do ponto de vista concetual nem de conhecimento das práticas verificadas nas bibliotecas digitais existentes. Um levantamento das políticas formais definidas e aplicadas para os principais projetos de bibliotecas digitais, quer de âmbito organizacional, temático ou nacional, seria um ponto importante para o conhecimento das orientações ideológicas e dos objetivos 
desta área. O mesmo se aplicaria a uma identificação das políticas informais. Também a definição dos intervenientes criadores das políticas de informação para a biblioteca digital constituiria um contributo valioso para a sustentação de projetos novos e reconfiguração dos já existentes. Note-se, aliás, que, apesar desta situação, alguns títulos de monografias e de artigos ostentam a expressão política da biblioteca digital mas não abordam aspetos como as componentes dessa política, o âmbito de aplicação, os intervenientes na sua elaboração ou o processo global de conceção, formulação, aplicação e avaliação dessa política.

As abordagens às bibliotecas digitais têm sido essencialmente de ordem prática, orientadas para a criação de coleções de recursos e serviços digitais. A atenção com aspetos conceptuais, teóricos e ideológicos tem sido diminuta. Neste cenário, compreende-se a existência de uma reflexão escassa sobre o meta-domínio da política de informação. Isto não invalida que a biblioteca digital seja pouco mais do que um contentor para um conteúdo caso não tenha uma política. É a política que torna a biblioteca digital viável, conferindo-lhe estrutura interna e situando-a num espaço informacional externo (Innocenti; et al., 2011). Assim, a política de informação da biblioteca digital deve ser encarada como uma racionalização intelectual que enquadra a conceção e o funcionamento da biblioteca digital, nas suas relações internas e externas. Todos os níveis da biblioteca digital têm de absorver e operacionalizar as ideologias e orientações da política (intrínseca e extrínseca). Aliás, como demonstrou Dalbello (2008), as bibliotecas digitais concebidas e existentes no espaço europeu foram claramente marcadas pelas orientações políticas de nível macro, tomadas ao nível da Comissão Europeia, e de nível organizacional, definidas no contexto das diversas bibliotecas nacionais que as promoveram. As políticas nacionais constituem outra influência decisiva para as bibliotecas digitais, tal como foi evidenciado por Joint (2009) para o caso dos modelos de acesso à produção académica de dissertações e teses, no Reino-Unido e nos EUA.

Além disso, deve notar-se que os poucos trabalhos relacionados com a política de informação para as bibliotecas digitais 
centram o seu foco em questões técnicas e tecnológicas, sendo quase inexistentes as abordagens com preocupações organizacionais e semânticas. A política de preservação (Smith; Moore, 2007) e a política de interoperabilidade (Innocenti; Vullo; Ross, 2010; Innocenti et al., 2011) constituem as duas áreas mais estudadas, visando a formulação de regras e procedimentos para garantir o acesso a longo prazo dos frágeis artefactos da biblioteca digital e criar condições de comunicabilidade tecnológica entre diferentes bibliotecas digitais.

Como assinalado por Innocenti et al. (2011, p. 112), no contexto das bibliotecas digitais, a palavra política tem associada a si uma grande carga polissémica, carecendo de um significado claro e esclarecedor, já que abrange uma significativa gama de documentos que a materializam, campos de aplicação diversos e níveis de conceptualização e de operação:

In real-world digital libraries, policies are usually packages of rules and guidelines, with background information, implementations details and consequences, that are used to conduct businesses in a orderly manner these definitions encompass different types of policies, e.g., management and funding policies, copyright policies (on content and on metadata), privacy policies, security policies, business rules and quality of service specifications, and collection development policies.

Nesta aceção, a política de informação pode ser considerada como um meta-conceito capaz de assimilar perspetivas distintas, encaradas frequentemente de modo isolado apesar das suas ligações implícitas e explícitas.

Pré-requisitos de uma política de informação para a biblioteca digital

Um cuidado importante a ter na definição da política de informação para a biblioteca digital diz respeito ao seu âmbito sociotécnico. Kajberg e Kristiansson referiam isso mesmo, criticando a 
ênfase excessiva nos aspetos tecnológicos das políticas de informação globais, nos seguintes termos:

Until recently many approaches to information policy-making have been one-sided in that they have mainly adhered to the purely technological aspect. Information policy makers have ignored the fact that the technology does not exist in a vacuum but a technological practice must be viewed as an interaction between cultural, organizational and technical aspects (Kajberg; Kristiansson, 1996, p. 8).

Considerando a biblioteca digital como uma rede de ferramentas tecnológicas, conteúdos e serviços que podem ser localizados e acedidos remotamente, apresentando como caraterísticas o fato de toda a sua informação ser digital, estar conectada em rede, ter catálogos públicos em linha, permitir o acesso remoto a recursos de informação de outras bibliotecas ou repositórios e oferecer acesso universal a documentos digitais (Torres Vargas, 2005), a componente tecnológica é primacial mas não pode ser isolada da sua inserção social. A biblioteca digital não pode ser pensada, construída e utilizada apenas como um armazém de metadados e de itens de informação, com funcionalidades de pesquisa e de acesso à informação. Nesse caso, as bibliotecas digitais não constituirão mais do que motores de pesquisa especializados. À semelhança das bibliotecas tradicionais, as bibliotecas digitais devem ser o reflexo das comunidades às quais se dirigem, selecionando recursos e desenvolvendo serviços em consonância com a sua missão. Mas libertada dos constrangimentos físicos, a biblioteca digital deve orientar-se para a construção de um ambiente informacional destinado à partilha de saber, através da criação, por parte dos utilizadores, de anotações, de relações entre recursos, de comentários e resumos, formando não só utilizadores-leitores mas também utilizadores-contribuidores/produtores (Lagoze, 2005).

Meghini, Spyratos \& Yang (2010) estipulam que para se falar de biblioteca digital é necessária a existência de um conjunto de objetos digitais e de serviços que facultem o acesso e a utilização repetida por parte dos utilizadores. Estes deverão poder realizar 
as seguintes tarefas no contexto da biblioteca digital: criar objetos novos e complexos através da reutilização de objetos pré-existentes enquanto conteúdos, proporcionar representações de um objeto criado, descrever objetos de acordo com um vocabulário selecionado, descobrir objetos a partir dos conteúdos ou das suas representações, visualizar representações, de conteúdos ou das descrições de um objeto, e identificar objetos de interesse, podendo atribuir-lhes uma identidade.

A biblioteca digital cumprirá assim uma missão orientada para o que poderemos apelidar de "inteligência informacional" (Boisvert, 2010), numa derivação da inteligência emocional tal como definida por Coleman, proporcionando conteúdos organizados, explorados e aproveitados através de serviços que maximizam as sinergias entre os produtores e os utilizadores da informação, favorecendo um ciclo contínuo de produção do conhecimento com redes de partilha total de trabalho, recursos e resultados.

O universo da política de informação na biblioteca digital

De acordo com Gonçalves (2004), as bibliotecas digitais são sistemas de informação complexos que necessitam de fundações formais. Assim, as políticas de informação apresentam-se como uma componente nuclear para compreender e estruturar as relações de complexidade existentes entre os elementos da própria biblioteca digital e o seu meio-ambiente. Aliás, na perspetiva deste autor, as políticas remetem para os aspetos socioeconómicos e legais que enquadram a biblioteca digital, pelo que interessam essencialmente para as relações extrínsecas da biblioteca. É, por exemplo, neste âmbito que se determinam as comunidades de utilizadores da coleção. Mas também as relações intrínsecas são consideradas, quando refere que as políticas se aplicam às categorias de documentos a integrar ou a serviços específicos, como a autenticação ou a escolha de protocolos.

No Digital Library Manifesto, desenvolvido no âmbito do DELOS Network of Excellence on Digital Libraries e publicado em 
2007, os conceitos estruturantes do universo da biblioteca digital incluem a arquitetura, os utilizadores, os conteúdos, as funcionalidades, a qualidade e a política (Candela, et al., 2007). O âmbito da política é, em termos gerais, o que Gonçalves definiu em 2004. Engloba políticas intrínsecas e extrínsecas à biblioteca digital, criadas de raiz ou resultantes da redefinição de políticas já existentes. Poderemos notar que a política é uma das caraterísticas da biblioteca digital mas é igualmente uma condição de existência da própria biblioteca, o que só poderá ser entendido se incluirmos aqui as políticas implícitas e não apenas as explícitas. Neste sentido, o DELOS apresenta o conceito de "política" como representando "set or sets of conditions, rules, terms and regulations governing interaction between the Digital Library and users, whether virtual or real" (Candela, et al., 2007).

Os utilizadores devem ser entendidos como todos os atores (humanos ou máquinas) que interagem no cenário da biblioteca digital, onde se estabelece a relação entre esses atores e a informação, favorecendo a sua capacidade de uso e transformação criativa, no intuito de gerar nova informação. Trata-se de um conceito abrangente que inclui a gestão desses atores, os seus direitos, os perfis personalizados de cada tipologia ou a sua colaboração. No universo da biblioteca digital, são identificados quatro tipos complementares de papéis para os seus atores: de utilizador final, de administrador do sistema, de designer e quem desenvolve aplicações para a biblioteca digital.

Já o conceito de funcionalidade envolve todos os serviços que a biblioteca digital proporciona aos seus diferentes tipos de utilizadores e requisitos específicos dos recursos de informação que constituem a coleção.

Os conteúdos incluem todos os dados e informação que a biblioteca digital contém e que estão disponíveis para os utilizadores, integrando objetos de informação em todas as suas vertentes (objetos primários, objetos complexos, identificadores, descrições e metadados).

A qualidade diz respeito aos parâmetros que podem ser usados para caracterizar e avaliar o conteúdo e o comportamento da 
biblioteca digital. A qualidade pode estar associada ao conteúdo, às funcionalidades ou aos objetos e serviços de informação da biblioteca digital. Os parâmetros serão de natureza objetiva ou subjetiva.

Por fim, a arquitetura constitui o mapa das funcionalidades e dos conteúdos da biblioteca digital, proporcionados através de hardware e de software, incluindo os aspetos de interoperabilidade.

Nesta configuração do universo da biblioteca digital, delineado pelo DELOS, importa ainda distinguir com rigor três noções nucleares: biblioteca digital, sistema da biblioteca digital e sistema de gestão da biblioteca digital. Trata-se de três "sistemas" distintos que no seu conjunto integrado constituem o universo da biblioteca digital. A biblioteca digital é definida como "A possibly virtual organization that comprehensively collects, manages, and preserves for the long term rich digital content, and offers to its user communities specialized functionality on that content, of measurable quality and according to codified policies" (Candela, et al., 2007). Sublinhe-se que são identificadas apenas as políticas codificadas, portanto, formais e explícitas, o que se afigura redutor, na medida em que não atende à cultura e práticas instituídas, não materializadas num discurso oficial assumido. $\mathrm{O}$ sistema da biblioteca digital compreende um software que assenta numa determinada arquitetura e proporciona as funcionalidades requeridas. O sistema de gestão da biblioteca digital corresponde a um software de sistema que proporciona a estrutura adequada para criar e gerir o sistema de biblioteca digital incorporando as funcionalidades básicas das bibliotecas digitais e permitindo a integração de software adicional para funcionalidades mais avançadas ou específicas.

$\mathrm{Na}$ continuidade do DELOS, o DL.org Project concebe a política de informação da biblioteca digital como uma especificação das políticas de informação: "[...] policies and practices that are established and implemented by digital libraries regarding the creation, organization, use and dissemination of the knowledge are themselves information policies and they have a tremendous 
impact on the accessibility of information contained in those digital libraries" (Innocenti; Vullo; Ross, 2010, pp 31-32). Nesta aceção, a política de informação involucra as fases do ciclo de vida da informação/conhecimento na biblioteca digital (criação, organização, uso e disseminação) pelo que tem uma existência operacional, através do estabelecimento de regras e condições de funcionamento, não podendo ficar-se por uma conceção teórica, influenciando diretamente o acesso aos recursos informacionais da biblioteca digital.

No documento súmula das opções teóricas e metodológicas assumidas pelo DL.org project, o conceito de política da biblioteca digital é apresentado como "[...] the set or sets of conditions, rules, terms and regulations governing every single aspect of the Digital Library service including acceptable user behaviour, digital rights management, privacy and confidentiality, charges to users, and collection formation" (Candela, 2011, p. 21). O mesmo documento, numa interessante esquematização através de mapa conceptual, mostra o domínio da política como categorizável consoante as suas características ou o seu âmbito. Do ponto de vista das características, o modelo distingue oito subclasses bipolares: política extrínseca $v s$ política intrínseca, política implícita $v s$ política explicita, política prescritiva $v s$ política descritiva e política imposta $v s$ política voluntária. Quanto ao âmbito, a política pode direcionar-se para o sistema como um todo, sendo uma "política sistémica", ou para domínios específicos da biblioteca digital, como por exemplo, no caso da política para os utilizadores ou da política para os conteúdos (Candela, 2011). 
Políticas de informação para bibliotecas digitais...

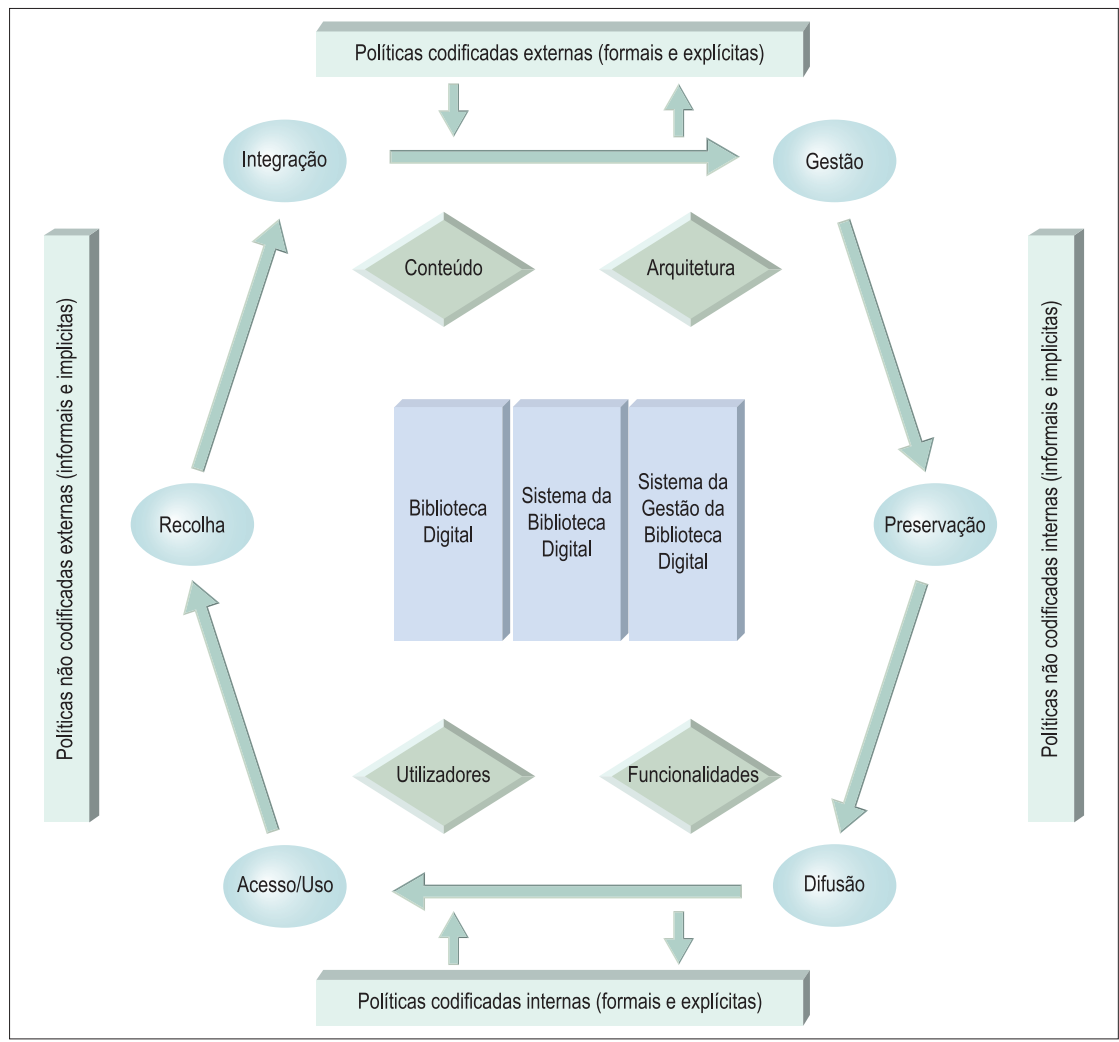

Figura 2.

O universo da política de informação na biblioteca digital

Conjugando quatro conceitos estruturantes da biblioteca digital (a arquitetura, os utilizadores, os conteúdos, as funcionalidades) e as noções centrais de biblioteca digital, sistema da biblioteca digital e sistema de gestão da biblioteca digital com políticas codificadas (formais e explícitas) externas e internas e políticas não codificadas (informais e implícitas) externas e internas, no ciclo contínuo das etapas de vida da informação (recolha, integração, gestão, preservação, difusão e acesso/uso), pode desenhar-se o universo da política de informação na biblioteca digital (Figura 2). 
Componentes da política de informação da biblioteca digital: proposta preliminar

Partindo dos conceitos identificados no universo da política de informação da biblioteca digital, obtém-se uma base para a identificação das componentes dessa política, as quais poderão constituir uma base de trabalho a ser usada como matriz para a elaboração de uma política formal ou para identificar e orientar políticas informais. Pode ainda ser um instrumento útil enquanto grelha de levantamento e de análise de políticas formais e informais existentes em bibliotecas digitais.

Contudo, este, ou qualquer outro modelo, deve ser avaliado no contexto real de cada biblioteca digital, da entidade promotora e do seu meio-ambiente geral e específico. Deverá atender aos interesses de todas as partes envolvidas, considerando a forma como os atores da biblioteca digital reagem à sua aplicação. Importa ainda averiguar a sua capacidade para criar um quadro conceptual, ideológico e organizacional da biblioteca considerando as suas características multidimensionais, numa abordagem integradora que ultrapasse a fragmentação.

Para definir o conceito de política de informação, alguns autores (Benkler, 1998; Browne, 1997b; Hernon; Relyea, 2003) optam por enfatizar o ciclo de vida da informação. O mesmo pode ser feito com proveito para o ciclo de vida específico da informação na biblioteca digital. Este ciclo de vida é configurado por seis etapas encadeadas (recolha, integração, gestão, preservação, difusão e acesso/uso), as quais se organizam em processos e atividades específicas, numa dinâmica que enquadra e é enquadrada pelas quatro entidades "naturais" da biblioteca digital (conteúdo, arquitetura, funcionalidades e utilizadores), no cenário da biblioteca digital, do sistema da biblioteca digital e do sistema de gestão da biblioteca digital.

Para uma tentativa de identificação das componentes da política de informação da biblioteca digital, as etapas do ciclo de vida da informação são úteis na definição dos parâmetros desta política porque têm capacidade para integrar as perspetivas humana, 
organizacional e tecnológica. Esta foi já uma opção seguida em parte por Green, Macdonald \& Rice (2009) no guia para formulação de uma política em repositórios institucionais. Os autores consideraram o âmbito de cobertura do repositório, os metadados, a integração, o acesso, a preservação e a eliminação de recursos. Portanto, este modelo para a formulação de uma política para repositórios não se cinge ao ciclo de vida da informação, mas considera já algumas dessas etapas. De seguida, iremos procurar especificar esse modelo de acordo com o ciclo de vida da informação na biblioteca digital (Figura 3), considerando o universo identificado na Figura 2.

No que concerne à recolha, cabe aqui explicitar as áreas temáticas da biblioteca digital, as tipologias informacionais, os formatos, bem como o volume ou o tamanho dos ficheiros a incluir. Também as opções relativas à infraestrutura tecnológica de armazenamento devem ser consideradas neste cluster. Na integração importa estabelecer os atores da biblioteca digital que podem alimentar a coleção (membros acreditados mediantes critérios pré-definidos, funcionários da biblioteca digital, etc.), escolha das modalidades de submissão de novos conteúdos ou ponderar a necessidade de existência de um moderador dos conteúdos integrados. A responsabilidade sobre a legalidade e a qualidade dos materiais integrados deve ficar explicita e é geralmente um ónus dos autores. Importa também refletir sobre a avaliação prévia dos conteúdos que são apresentados para submissão e sobre a pertinência de um período de embargo para certos tipos de recursos. Os metadados são igualmente uma parte essencial a considerar na componente da integração. A atribuição da responsabilidade pela criação de metadados administrativos, descritivos, técnicos, estruturais ou de preservação representa um elemento essencial para o cumprimento das funcionalidades da biblioteca digital. 


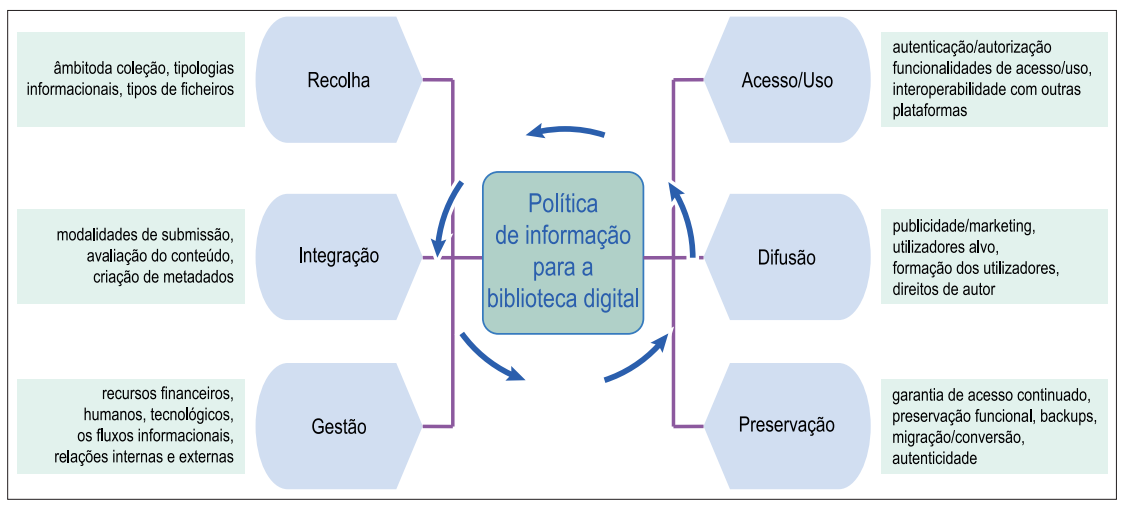

Figura 3.

Componentes da política de informação da biblioteca digital

A gestão terá de incidir sobre os recursos financeiros, humanos, tecnológicos e sobre os fluxos informacionais. Terá de definir os requisitos do software do sistema de gestão da biblioteca digital que dará corpo ao sistema da biblioteca digital. Aqui serão ainda configurados os papéis dos atores da biblioteca digital e a estrutura organizacional em que se enquadram, com as respetivas relações hierárquicas. As interações com outras entidades externas à biblioteca digital serão consideradas neste cluster, incluindo as condições de interoperabilidade que permitiram o diálogo tecnológico e semântico.

A preservação dos artefactos integrados na biblioteca digital garante o seu acesso continuado e representa um aspeto crucial da política de informação. Importará considerar aspetos de preservação funcional incluindo opções relativamente às condições de backups, de migração, de reconversão, entre outras. A opção fundamentada por um modelo de preservação constituirá também um item importante. Os requisitos para a garantia de autenticidade e de confiabilidade dos registos poderão igualmente ser pensadas neste cluster.

Na difusão deverão ser considerados aspetos como a publicidade e marketing da biblioteca digital, a definição dos grupos-alvo, a sua formação para o uso dos serviços e recursos disponíveis, os 
requisitos de usabilidade, incluindo os adequados para pessoas com necessidades especiais, e o respeito pela legislação do direito de autor e copyright.

Por último, no cluster do acesso/uso, terão cabimento as questões relacionadas com a autenticação e autorização de acesso dos utilizadores da biblioteca digital, as opções de download, com a existência de funcionalidades para criar uma área de utilizador ou a interoperabilidade com outras bibliotecas digitais, integrando recursos.

\section{CONCLUSÃO}

A política é inerente à biblioteca digital permeando-a transversalmente desde a sua conceptualização até ao funcionamento. Neste pressuposto, a política de informação da biblioteca digital tem de ser concebida e aplicada como um plano de desenvolvimento e de concretização global, integrando e coordenando componentes diversas num sistema multidimensional complexo. Aqui, o elemento tecnológico não constitui uma componente isolada porque ele está imerso e configura o universo da biblioteca digital na sua totalidade, o que implica que não deva ser considerado isoladamente.

Atualmente, o grau de formalização das políticas das bibliotecas digitais é pouco significativo, restringindo-se a áreas parcelares, como a preservação, a interoperabilidade ou a segurança. Assim, um dos desafios para a política de informação de qualquer biblioteca digital será não apenas uma formulação mas igualmente uma implementação global e integradora. Isso implicará uma dinâmica constante de adaptação entre as suas componentes e o meio-ambiente externo, fundamentada numa abordagem socio-técnica propícia para a sustentação de um quadro concetual e ideológico da projeto da biblioteca digital. Será uma infraestrutura teórica capaz de integrar as perspetivas tecnológica, organizacional e humana da biblioteca digital. 


\section{REFERÊNCIAS BIBLIOGRÁFICAS}

Arnold, Anna-Maria, "Developing a national information policy: considerations for developing countries", The international information \& library review, Núm. 2 (2004), pp 199-207.

Atherton, Pauline, Manuel pour les systèmes et services d'information, París: UNESCO, 1977.

Benkler, Yochai, The commons as a neglected factor of information policy [on line], disponível na: http://www.benkler.org/commons. pdf, presentation at the 26th Annual Telecommunications Research Conference, Oct. 3-5, 1998 [acedido 17.07.2012].

Boisvert, Danielle, dir. De, Le développement de l'intelligence informationnelle: les acteurs, les défis et la quête de sens, Montréal: Éditions ASTED, 2010.

Braman, Sandra, "The unique characteristics of information policy and their us consequences", en Blake, V.; Tjoumas, R., eds., Information literacies for the twenty-first century, Boston, Ma: Hill, 1990, pp 47-77.

Browne, Mairéad, "The field of information policy: 1: fundamental concepts", en Journal of information science, Vol. 23, Núm. 4 (1997a), pp 261-275.

Browne, Mairéad, "The field of information policy: 2: redefining the boundaries and methodologies", en Journal of information science, Vol. 23, Núm. 5 (1997), pp 339-351.

Candela, Leonardo; et al., "Setting the foundations of digital libraries: The Delos Manifesto", en D-Lib Magazine [Em linha]. Vol 13, Núm. 34 (2007), disponível na: http://www.dlib.org/dlib/march07/ castelli/03castelli.html, [acedido 17.07.2012]. 
Candela, Leornardo; et al., "The Digital Library Reference Model”, [on line], abril 2011, disponível na: http://bscw.research-infrastructures.eu/pub/bscw.cgi/d222816/D3.2b\%20Digital\%20Library\%20 Reference\%20Model.pdf, [acedido 17.07.2012].

Dalbello, Marija, "Cultural dimensions of digital library development, part I: theory and methodological framework for a comparative study of the cultures of innovation in five European national libraries", en The library quarterly. Vol. 78, Núm. 4 (2008), pp 355-395.

Gonçalves, Marcos André, Streams, Structures, Spaces, Scenarios, and Societies (5S): A Formal Digital Library Framework and Its Applications [em linha], 2004. Dissertação de doutoramento apresentada à Virginia Polytechnic Institute and State University, disponível em: http://scholar.lib.vt.edu/theses/available/ etd12052004135923/unrestricted/MarcosDissertation.pdf, [acedido 09.07.2012].

Green, Ann; Macdonald, Stuart; Rice, Robin, Policy-making for research data in repositories: a guide [on line], 2009, disponível em: http://www.disc-uk.org/docs/guide.pdf, [acedido 18.07.2012].

Grolier, Eric de, "Perspectivas en política bibliotecaria y de información y la herencia de Ranganathan", en Boletin de ANABAD. Vol. XLIII, Núm. 1 (1993), pp 69-83.

Hernon, Peter; Reyla, Harold C., "Information policy", en drake, Miriam A., Encyclopedia of library and information science, 2nd ed. New York; Basel: Marcel Dekker, 2003, Vol. 2, pp 1300-1315.

Innocenti, Perla; et al., "Towards a holistic approach to policy interoperability in digital libraries and digital repositories", en The international journal of digital curation, Vol. 6, Núm. 1 (2011), pp 111-124. 
Innocenti, Perla; Vullo, Giuseppina; Ross, Seamus, "Towards a digital library policy and quality interoperability framework: the DL.org Project", en New Review of Information Networking, Vol 15, Núm. 1 (2010), pp 29-53.

Joint, Nicholas, "Online digital thesis collection and national information policy", en Library review, Vol. 58, Núm. 8 (2009), pp 562-568.

Kajberg, Leif; Kristiansson, Michael, "An overview of the field of information policy", en International forum on information and documentation, Vol. 21, Núm. 1 (1996), pp 5-9.

Karni, Reuven, "A methodological framework for formulating information policy", en Information \& management, Vol. 6, Núm. 5 (1983), pp 269-280.

Lagoze, Carl; et al., "What Is a Digital Library Anymore, Anyway? Beyond Search and Access in the NSDL", en D-Lib Magazine. Vol. 11, Núm. 11 (2005).

Maxwell, Terrence A., "Toward a model of information policy analysis", en First monday [em linha]. Vol. 8, Núm. 6 (2003). Disponível na: http://firstmonday.org/htbin/cgiwrap/bin/ojs/index.php/fm/ article/view/1060/980, [acedido 17.07.2012].

Meghini, Carlo; Spyratos, Nicolas, Yang, Jitao, "A data model for digital libraries", en International Journal on Digital Libraries, Vol. 11, Núm. 1 (2010), pp 41-56.

Montviloff, Victor, Politiques nationales de l'information: manuel concernant la formulation, l'approbation, la mise en ouvre et l'action d'une politique nationale de l'information, París: UNESCO, 1990. 
Moore, Nick, "Neo-liberal or dirigiste? Policies for an Information Society", en Rowlands, Ian, ed., Understanding information policy: proceedings of a workshop held at Cumberland Lodge, Windsor Great Park, 22-24 July, 1996, London: Bawker Saur, 1997, pp 89-100.

Morales, Estela, "The information right and the information policies in Latin America", en IfLA General Conference and Council, 65th, Bangkok, 20-28.08.1999, On the threshold of the 21st Century: $l i$ braries as gateways to an enlightened world [em linha], disponível na: http://ifla.queenslibrary.org/IV/ifla65/papers/056-137e.htm, [acedido 17.07.2012].

Orna, Elizabeth, Practical information policies: how to manage information flow in organizations, $2^{\mathrm{a}}$ ed. Aldershot: Gower, 1999.

Overman, E. Sam; Cahill, Anthony G., "Information policy: a study of values in the policy process", Review of policy research, Vol. 9, Núm. 4 (1990), pp 803-818.

Rowlands, Ian, "Information policy", en Feather, John; Sturges, Paul, ed., International encyclopedia of information and library scien$c e$, 2nd ed. London; New York: Routledge, 2003a, pp 278-285.

Rowlands, Ian, "Information policy: complexity, scope and normative structure", en Hornby, Susan; Clarke, Zoë - Challenge and change in the information society, London: Facet Publishing, 2003b.

Silva, Armando Malheiro da; Ribeiro, Fernanda, Das "ciências" documentais à ciência da informação: ensaio epistemológico para um novo modelo curricular, Porto: Edições Afrontamento, 2002.

Smith, Mackenzie; Moore, Reagan W, "Digital archive policies and trusted digital repositories", en The international journal of digital curation, Vol. 2, Núm. 1 (2007), p 92-101. 
Torres Vargas, Georgina Araceli, La biblioteca digital, México: UNAM, CUIB, 2005.

United States. President's Science Advisory Committee, Science, government, and information: the responsibilities of the technical community and the Government in the transfer of information: a report, Washington, u.s. Government Printing Office, 1963.

Wesley-Tanaskovíc, Ines, Principes directeurs relatifs aux politiques nationales de l'information: portée, formulation et mise en ouvre, Paris: UNESCO, 1985. 


\title{
El desarrollo de colecciones de libros electrónicos en las instituciones de educación superior
}

\author{
Miguel C. GAMA RAMÍREZ \\ Universidad Nacional Autónoma de México
}

\section{INTRODUCCIÓN}

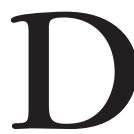

esde sus orígenes, las bibliotecas académicas han ofrecido a sus comunidades de usuarios un conjunto amplio de colecciones de unidades documentales que presentan múltiples formatos y que varían según el tiempo y los desarrollos prevalecientes en cada etapa del devenir humano. De esta forma hemos presenciado, a través del tiempo, como parte del universo de los acervos de información, las tabletas de arcilla sumerias, los manuscritos medievales, los rollos de papiro, los códices, los microfilms, las microfichas, los disquetes, los discos compactos y los materiales audiovisuales, entre otros, y desde la década de los setenta los denominados contenidos digitales.

Pese a lo anterior, el libro impreso, hasta antes de la segunda mitad del siglo, se erigió como el soporte idóneo para la transmisión y preservación del conocimiento; su presencia en las bibliotecas académicas del mundo así lo confirma. Sin embargo, el advenimiento de Internet y el uso masivo de las Tecnologías de Información y Comunicación (TIC) contribuyeron al nacimiento del llamado libro electrónico. En consecuencia, resulta necesario revisar y analizar el proceso de incorporación de este nuevo soporte al espectro de las colecciones académicas de las bibliotecas como otra forma de organizar, transmitir y preservar el conocimiento. 
Las líneas siguientes exponen la incorporación del libro electrónico en el contexto del desarrollo de colecciones de la biblioteca académica. De manera general, se anota la situación en el contexto internacional en algunos países de Europa (España, Reino Unido e Italia). Después, se realiza una revisión en los Estados Unidos y, finalmente, se describe la situación en una institución en el expediente mexicano.

\section{CONTEXTO INTERNACIONAL}

Se afirma que, a partir de la Declaración de Bolonia del 25 de mayo de 1998, se elaboró un nuevo modelo educativo que, en consecuencia, conllevó al surgimiento de un nuevo modelo de Biblioteca (Moscoso, 2003).

En esa ocasión los ministros europeos de educación destacaron el papel central que desempeñaron las universidades en el desarrollo de las dimensiones culturales europeas.

Después de la Declaración de Budapest (Hungría, 1999), se enfatizó, entre otros puntos, que la revolución de información y la comunicación ofrecía medios nuevos y más eficaces para intercambiar los conocimientos científicos y hacer progresar la educación y la investigación. Así, se observa que los contenidos digitales referidos a los libros electrónicos cobraron enorme relevancia en la perspectiva del desarrollo de colecciones y de la oferta de servicios bibliotecarios y de información para las comunidades académicas integrantes de las instituciones de educación superior.

\section{Europa}

\section{España}

En la experiencia española, los trabajos de Merlo Vega (2000), Rodríguez Bravo (2004), Pérez Arranz y Moscoso (2007), Clavero (2009) y Alonso Arévalo y Cordon García (2010) y Cordón García 
y Lopes (2011) son fundamentales para conocer el proceso de incorporación del libro electrónico en las bibliotecas académicas.

Uno de los primeros trabajos de evaluación de los libros electrónicos en las bibliotecas universitarias españolas se debe a Rodríguez Bravo, quien concentró su análisis, primordialmente, en las contrataciones de contenidos digitales de proveedores comerciales.

De esta forma, se identificaron libros de sellos editoriales como Elsevier, Kluwer, Springer, Wiley, Emerald; así como los modelos de E-libro, Netlibrary y Safari. Tres años después, la investigación de Pérez-Arranz y Moscoso (2007) reveló que, de un total de 65 universidades, sólo 36 de ellas ofrecían desde 2003 el acceso a libros electrónicos. Dos años más tarde, el mismo servicio se extendía a 50 universidades. Lo anterior significó que en pocos años el libro electrónico se fue incorporando gradualmente a las colecciones de las bibliotecas académicas en la península ibérica.

De los cinco consorcios de bibliotecas universitarias anotados en ese país la adquisición e integración de los libros electrónicos se centralizó en las bibliotecas andaluzas, catalanas y gallegas. Llama la atención en el terreno español que el acceso a los contenidos digitales se ofreció a través de compra o suscripción realizada a través de consorcios, lo que permitió a las instituciones participantes en esos grupos de compradores ofrecer a sus comunidades más contenidos con menos recursos económicos, porque, al formar la "bolsa" de recursos, las aportaciones se definen de acuerdo con el tamaño de las instituciones; de esta forma, a unas les corresponde aportar más y a otras menos de acuerdo a su capacidad monetaria, pero lo importante es que al final todos los participantes salen beneficiados.

Al respecto Pérez-Arranz y Moscoso enfatizan que "Los consorcios de bibliotecas constituyen la forma más eficiente y eficaz de desarrollar colecciones de libros electrónicos, por lo que es aconsejable incluir la compra consorciada de este tipo de recursos en su política de adquisiciones". ${ }^{1}$

1 Fernando Pérez-Arranz y Purificación Moscoso, "El libro electrónico y su incidencia en las bibliotecas universitarias y científicas españolas", en: Revista Española de Documentación Científica, 30 (3), jul.-sep., 2007, p. 360. 
Los modelos de negocios de libros electrónicos imperantes fueron Netlibrary, Safari y E-Libro, principalmente. El idioma prevaleciente fue el inglés y las formas de acceso a los contenidos se estableció a través de los catálogos en línea, de una lista de títulos en la página web de la biblioteca, y del enlace al portal de los contenidos digitales, previamente reconocidos por dirección electrónica de la institución o claves particulares.

Por su parte, Alvite y Rodríguez Bravo señalan, en un estudio de 2006, que los libros electrónicos contratados correspondieron a literatura, ingeniería y a los materiales del distribuidor de contenidos electrónicos del IEEE.

A partir del análisis de la información contenida en los sitios web de las bibliotecas universitarias españolas, estos investigadores encontraron que Safari estaba presente en 24 universidades; E-libro, en 16; Serie Lecture Notes, en 14; Netlibrary, en 12; Literature Online, en 11; SpringerLink Electronic Book Library, en 10; IEEE y Early English Books, en 9; E-books de ScienceDirect, en 6; CRC Press, en 4, y finalmente, Engineering Village2, en 3. Como se puede observar, hay diversidad de modelos y de temáticas, y si bien la información señalada representa un primer acercamiento a la situación del libro electrónico en las universidades públicas españolas, también hay que resaltar que no todos los contenidos digitales fueron fácilmente identificados, ni mucho menos analizados.

La situación antes señalada revela una de las características de la situación del libro electrónico en las instituciones de educación, cuya identificación no es precisa porque en algunos casos aparecen en los catálogos públicos en línea, en otros en los sitios de los proveedores, y en unos más en las bases de datos contratadas, razón por la cual los tradicionales inventarios del material bibliográfico impreso son también necesarios en los entornos digitales. Sin embargo, hay que recalcar que las instituciones educativas deben contar con los mecanismos de registro que les permitan tener a la mano, siempre, datos precisos y confiables de sus acervos digitales. 
Desde la década de los noventa, con el establecimiento del Comité Conjunto de Sistemas de Información (Joint Information Systems Committee), en el Reino Unido se llevaron a cabo un conjunto de acciones en torno al estudio de los sistemas de información, la infraestructura tecnológica y los contenidos digitales para uso y beneficio de las instituciones de educación y sus comunidades académicas.

Autores como Armstrong y Lonsdale (1997), Snowhill, Woodward (2001), Armstrong, Edwards y Lonsdale (2002) y Hernández Salazar, Nicholas y Rowland (2009), entre otros, han revisado la situación del libro electrónico en las bibliotecas universitarias del Reino Unido.

En 1997 Armstrong y Lonsdale realizaron una investigación en torno a la edición de monografías académicas en línea y libros de texto. Los resultados revelaron el surgimiento de una industria editorial de libros electrónicos con un mercado incierto en el sector de bibliotecas académicas.

Más tarde, Lonsdale y Armstrong (2001) reflexionaron sobre los cambios en las bibliotecas académicas ante la presencia de los libros electrónicos, y Snowhill, en torno al futuro de éste en las bibliotecas académicas.

Mientras tanto, el JISC promovía la formación de un grupo de actores con integrantes de la industria editorial, académicos investigadores en el campo del libro electrónico y representantes bibliotecarios de colegios y universidades del Reino Unido, quienes realizaban estudios sobre los licenciamientos, el acceso y uso del libro electrónico, las revistas electrónicas, las bases de datos y el control bibliográfico, entre otros tópicos de interés.

Años después, Hernández Salazar, Nicholas y Rowland (2009) analizaron la situación del estado que guardan los libros electrónicos en las bibliotecas de educación superior del Reino Unido bajo la perspectiva de la sociedad del aprendizaje. En los antecedentes del proyecto se anota la creación, en 1993, del Comité Conjunto de Sistemas de Información (Joint Information Systems 
Committee/JISC), el cual elabora el proyecto nacional con el fin de "analizar el estado actual del mercado de libros electrónicos entre las bibliotecas de educación superior y recomendar los roles potenciales [...] para apoyar el mercado."

El estudio señalado revela que los libros electrónicos presentes en las bibliotecas no necesariamente apoyaban los cursos; que los editores desconocían si los libros estaban disponibles dentro de la biblioteca, y que los actores principales (editores, distribuidores y bibliotecarios) no conocían en detalle los modelos de licencia y de precios.

Además, en dicho documento se indica que en 2007 se inició el Proyecto Observatorio Nacional de Libros Electrónicos del JISC National e-Books Observatory Project, basado en cuatro objetivos:

1. Obtener licencias para el uso de colecciones de libros electrónicos relevantes para los cursos de educación superior del Reino Unido en disciplinas como: Administración y Negocios; Ingeniería; Medicina (excepto Salud Mental y Enfermería), y Estudios de Medios.

2. Atraer la participación hacia el hecho de que los libros electrónicos estuvieran disponibles en las plataformas.

3. Evaluar el uso de los libros a través del método de análisis profundo de logs (Deep Log Analysis).

4. Informar de los resultados a los principales actores (editores, distribuidores y bibliotecarios).

El trabajo de Hernández Salazar, Nicholas y Rowland (2009) se centra en el objetivo número 3, con más de 20 mil respuestas procedentes de 123 universidades de todas las regiones geográficas del Reino Unido. Las preguntas giraron en torno a dos vertientes: el acceso y el uso de los libros electrónicos. Respecto al primero se observó que el acceso fue a través de la biblioteca y también de Internet. El uso de ellos alcanzó un 60\%.

Llama la atención que en la investigación anotada se utilizó un método cuantitativo llamado Análisis Profundo de Logs que esbo- 
za el mapa del usuario virtual, a fin de conocer el uso efectivo de los libros electrónicos. Los resultados obtenidos les permitieron a los autores sustentar el argumento del uso intensivo de los contenidos digitales dado el desglose de datos, tiempos, ubicación y títulos de las obras. Se estima que este método en particular podría llevarse a la práctica en otras instituciones de educación superior a fin de obtener datos duros en torno al uso efectivo de los libros electrónicos.

Por otra parte, en el expediente británico llama la atención la presencia del Observatorio Nacional de Libros Electrónicos, otro de los elementos que, se estima, debería figurar como parte de un modelo ideal del desarrollo de libros electrónicos en las instituciones de educación superior.

Además, se identificó la necesidad de establecer programas de formación para el uso de recursos digitales y que la mayoría de los títulos fueron contratados por suscripción.

\section{Italia}

Algunas de las principales instituciones de educación superior italianas instrumentan programas piloto de contenidos digitales a partir de 2000. Autores como Cirulli, C. (2006), Fiorentini, B. (2006) y Perrone, A. (2009) dan cuenta de ello. Por ejemplo, este último se pregunta cómo están administrando los bibliotecarios académicos la integración de las colecciones de libro electrónico a partir de los criterios de selección y de la política de desarrollo de colecciones.

El Politécnico di Milano inició en 2004 un proyecto piloto de integración de colecciones de libros electrónicos como herramienta de apoyo a las tareas de docencia y de investigación. Un comité científico se aboca a tareas de análisis sobre propuestas editoriales, evaluación de contenidos y de acceso, y de modelos de licenciamiento.

Dos años antes, la Universitá degli studi di Bologna había incursionado en materia de contenidos digitales al contratar la suscripción de la base de datos Engineering Handbook. En esa 
ocasión, el recurso fue seleccionado por bibliotecarios. Uno de los puntos sobresalientes de dicha experiencia fue la denominada estrategia de comunicación basada en tres rubros: a) involucrar a alumnos tesistas para utilizar el recurso; b) difundir la obra en el sitio de Internet de la universidad, y c) enviar mensajes por correo electrónico a estudiantes, bibliotecarios y profesores.

Los bibliotecarios decidieron integrar todos los títulos que formaban parte de la base en el catálogo al público en línea de la biblioteca. Uno de los elementos que llama la atención en este caso es el análisis de las estadísticas de uso del recurso. También observaron que se requería mayor flexibilidad en los modelos de licenciamiento a fin de que las bibliotecas tuvieran la libertad de seleccionar título por título en lugar de paquetes predefinidos o bases de datos.

Por su parte, la Universitá Cattolica del Sacro Cuore-Piacenza arrancó, en 2005, con un proyecto de libros electrónicos cuyos contenidos fueron seleccionados por personal bibliotecario, $\mathrm{y}$ que tomaron en consideración lo siguiente:

a) Título por título.

b) Acuerdo para el pago anual basado en el número de títulos suscritos.

c) Registro MARC de cada libro electrónico.

d) Acceso múltiple concurrente.

e) Búsqueda por título y por texto completo.

f) Herramientas que permitan la creación de notas y marcado de los textos.

g) Reportes estadísticos de uso de los contenidos.

Se suscribieron dos colecciones de libros electrónicos. Las estrategias implementadas para la difusión de los contenidos fueron diversas: colocar un enlace al recurso desde el sitio en Internet de la biblioteca, distribuir folletos entre los alumnos, y realizar entrevistas y cuestionarios a los usuarios.

En los casos anotados de Italia destacan dos características: la primera, la participación de bibliotecarios en la selección y ad- 
quisición de los libros electrónicos; y la segunda, la creación ex profeso de un comité científico para la selección y adquisición de este tipo de material.

Estados Unidos

Según Forrester Research, el mercado de libros electrónicos en los Estados Unidos se muestra halagador, dado que duplicó su tamaño en 2009 y, al año siguiente, se estimaba que alcanzaría unos 500 millones de dólares. Además, se prevé que alrededor de 50 millones de títulos se moverán a formato electrónico. Dado lo anterior se observa que el libro electrónico es un producto con fuerte presencia en el sector económico de la industria de la información a nivel internacional. Se estima que a mediano plazo será un insumo de consideración en las bibliotecas académicas.

El espectro de las instituciones de educación superior estadunidenses comprende múltiples casos de incorporación de contenidos digitales en los acervos bibliográficos desde los primeros años del año 2000. Los trabajos de Dillon, D. (2001), Langston, M. (2003), Benett, L., Christianson, M. y Marsha Aucoin (2005), Safley (2006), Levine Clark, M. (2007) y Nelson, M., Safley, Ellen (2008) ilustran lo anterior.

En el verano de 2000, la Universidad de Texas (UT) en Austin, le ofrecería a su comunidad alrededor de 20 mil libros electrónicos. De acuerdo con Dillon (2001), la UT decidió crear un comité que analizara los libros electrónicos en el contexto de la World Wide Web.

Los modelos presentes fueron Netlibrary e ITKnowledge. El primero adquirido en forma permanente y el segundo bajo suscripción. Las temáticas cubiertas fueron: ciencia de la computación, economía, negocios, medicina, sociología, historia americana y literatura.

Con base en la experiencia de libros electrónicos, los bibliotecarios de la Universidad de Texas adoptaron los lineamientos siguientes para la adquisición de los mismos: 
a) No a equipo y software propietario para la lectura y acceso a los contenidos.

b) Los libros electrónicos deberán ser parte integral de la red interna de cómputo.

c) Los libros electrónicos deberán ser persistentes en términos de contenido y acceso en red.

d) Los libros electrónicos serán amigables y no requerir conocimientos especiales o habilidades para su acceso $\mathrm{y}$ uso.

e) No requerirán autorizaciones, configuraciones o claves particulares.

f) Estarán disponibles en línea o fuera de ella.

\section{MÉXICO}

La Asociación Nacional de Universidades e Instituciones de Educación Superior contaba con 165 miembros en 2012, tanto del sector público como del privado. En el Distrito Federal se ubican 19 instituciones.

El sistema bibliotecario de la UNAM

Los antecedentes del sistema se remiten al origen y desarrollo de la Dirección General de Bibliotecas (DGB) y a los trabajos realizados durante el periodo de 1973 a 1990 para generar el marco jurídico de operación. A partir de 1990, el sistema quedó conformado y, en la actualidad, está integrado por 134 bibliotecas $^{2}$ que se ubican de la siguiente forma.

Institutos y Centros de Investigación Humanística 21

Institutos y Centros de Investigación Científica

2 Universidad Nacional Autónoma de México, Agenda estadística 2012, México: UNAM, Dirección General de Planeación, 2012 (disco compacto). 
Facultades

Unidades Multidisciplinarias

Escuelas

Escuela Nacional Preparatoria

Colegio de Ciencias y Humanidades 6

Administración y Extensión Universitaria

La organización y administración de las bibliotecas está contemplada en la Legislación Universitaria y como parte de la misma existe el Reglamento General del Sistema Bibliotecario ${ }^{3}$ cuya finalidad es la de establecer sus objetivos, funciones y operatividad. La DGB centraliza los procesos técnicos del material documental, la suscripción a revistas y recursos electrónicos y el desarrollo de los catálogos en línea. Asimismo, coadyuva en la supervisión de la aplicación racional de los recursos financieros asignados.

De acuerdo con los datos de la Agenda Estadística 2012, los libros impresos disponibles en las bibliotecas de la UNAM sumaron 2, 738, 472 títulos con 6, 882, 246 volúmenes; 431124 libros electrónicos; 26000 revistas electrónicas de texto completo y 158 bases de datos internacionales especializadas (104 referenciales y 54 de texto completo). ${ }^{4}$

Desarrollo de colecciones

Este proceso es fundamental para los objetivos de la institución considerando los planes y programas de estudios, así como las líneas de investigación establecidas; se lleva a cabo en forma permanente, con procedimientos específicos y con la participación de distintos actores representados en varios órganos colegiados.

3 Universidad Nacional Autónoma de México, Legislación Universitaria. Reglamento General del Sistema Bibliotecario. Disponible en: http://xenix.dgsca. unam.mx/oag/abogen/documento.html?doc_id=53

4 Universidad Nacional Autónoma de México, Agenda estadística 2012, unAm, Dirección General de Planeación, 2012 (disco compacto). 


\section{Selección}

Se cuenta con información pertinente en línea sobre editoriales, librerías y organismos internacionales que presentan la producción editorial en ámbitos nacionales e internacionales, así como la recepción de los tradicionales catálogos impresos que llegan a las bibliotecas de todas partes del mundo.

\section{Adquisición}

Se realiza con base en la normatividad para la compra de libros, y se tiene como fuente de referencia el Registro de Proveedores de Material Bibliográfico de la UNAM 2011-2013.

De acuerdo con los datos reportados en la Memoria UNAM $2011^{5}$ en torno a los recursos económicos destinados para el desarrollo de colecciones durante 2011, se asignaron $\$ 80,889,136.00$ pesos para la compra de libros, lo que representa un incremento del $5.8 \%$ respecto a 2010. Se adquirieron 64859 títulos impresos, que correspondieron a 132,422 volúmenes, así como 16,120 libros electrónicos y 8 bases de datos, lo que representa un monto de $\$ 77,383,616.77$ pesos.

Además, se renovaron 10,413 suscripciones a revistas técnicas y científicas, que corresponden a 6,690 títulos. El presupuesto para la adquisición de bases de datos y revistas técnicas y científicas, impresas y electrónicas, fue de $\$ 231,538,472.00$ pesos. Como se puede observar, son grandes inversiones económicas que realiza la institución para dotar a su comunidad de múltiples fuentes de información académica, por lo que se hace necesario el registro puntual de cada recurso, la bitácora en detalle del uso de los mismos y, por supuesto, la evaluación de los acervos digitales.

5 Universidad Nacional Autónoma de México, Memoria UNAM 2011, México: UNAM, Dirección General de Planeación, 2012 (disco compacto). 


\section{Colecciones de libros electrónicos}

En 2002 se convocó a un grupo de bibliotecarios procedentes de los subsistemas de bachillerato, licenciatura y posgrado, investigación científica, extensión y administración universitaria y las subdirecciones técnica, informática, servicios especializados, ${ }^{6}$ y a la secretaría técnica de la biblioteca digital de la Dirección General de Bibliotecas a fin de proponer políticas, lineamientos y procedimientos para el desarrollo de este tipo de colecciones.

La estructura se estableció con los siguientes subcomités:

1. Selección, adquisición y negociación con proveedores.

2. Infraestructura tecnológica.

3. Control bibliográfico.

4. Uso y evaluación del servicio.

5. Marco legal.

6. Financiamiento.

Cada grupo de trabajo desarrolló sus actividades en tiempo y forma. La participación del Comité en ferias de libros, seminarios, Jornadas Mexicanas de Biblioteconomía y en actividades de difusión in situ o a través de videoconferencias, avalan la premisa de éxito del trabajo colaborativo multidisciplinario y de lo oportuno del tema en la óptica de los recursos bibliotecarios y de información de la institución. En términos prácticos, el Comité estuvo en operación hasta 2008.

A continuación se muestran algunos ejemplos de las colecciones de libros electrónicos disponibles en 2012 para la comunidad universitaria:

6 Actualmente, se denomina Subdirección de Servicios de Información Especializada de la Dirección General de Bibliotecas de la UNAM. 
Biblioteca Digital Académica en Bibliotecología...

\begin{tabular}{|c|c|}
\hline Temas & Proveedor / Editor/ Agregador \\
\hline Ciencia de la Computación & ocLC Netlibrary \\
\hline \multicolumn{2}{|l|}{ Ciencias de la Tierra } \\
\hline \multicolumn{2}{|l|}{ Multidisciplinaria } \\
\hline Ciencias Ambientales, Cómputo, Matemáticas e Ingenierías & Springer Link \\
\hline Ciencias Biológicas y de la Salud & MD Consult \\
\hline \multirow[t]{5}{*}{ Ciencias Sociales y Humanidades } & Eighteenth Century \\
\hline & Collections Online (ECCO) \\
\hline & Thomson Gale \\
\hline & eatro español del Siglo de Oro \\
\hline & Early English Books Online (ЕЕВO) \\
\hline Computación e Ingenierías & ACM Digital Library \\
\hline Economía, Tecnología y Medio Ambiente & SourceoECD \\
\hline \multirow[t]{2}{*}{ Economía y Negocios } & Making of the Modern World (MOMw) \\
\hline & Thomson Gale \\
\hline Biología, Derecho, Filosofía, Lingüística & Oxford University Press \\
\hline Música y Psicología & Oxford Scholarship Online \\
\hline Ingeniería & Access Engineering (McGraw-Hill) \\
\hline Matemáticas & $\begin{array}{l}\text { Society for Industrial and Applied Mathe- } \\
\text { matics (SIAM) }\end{array}$ \\
\hline \multirow[t]{2}{*}{ Medicina } & McGraw-Hill \\
\hline & Ovid \\
\hline Multidisciplinaria & Kluwer \\
\hline Multidisciplinaria & Overdrive \\
\hline Tecnología de la Información & Safari Tech Books Online \\
\hline \multicolumn{2}{|c|}{ Contenidos locales } \\
\hline Multidisciplinario & UNAM / PAPIME / PAPIIT \\
\hline \multirow[t]{2}{*}{ Multidisciplinario } & ILCE / FCE \\
\hline & Ciencia para Todos \\
\hline
\end{tabular}

\section{Obras de consulta}

Encyclopedia Britannica

Encyclopedia of Library and Information Science 
Encyclopedia of Life Sciences

Routledge Encyclopedia of Philosophy Online

Los ejemplos anotados representan cientos de miles de títulos de libros electrónicos en casi todas las disciplinas del conocimiento; algunos se han adquirido en compra permanente y otros permanecen bajo el esquema de arrendamiento, por lo general de suscripción anual. Los principales sellos editoriales, sobre todo internacionales, están presentes en el formato digital. Todos estos títulos están disponibles para cada uno de los miembros de la comunidad universitaria en el tenor de los servicios bibliotecarios y de información.

\section{DisCUSIÓN}

La primera década del siglo XXI muestra un crecimiento exponencial de los contenidos digitales en material editorial y una incorporación gradual en las bibliotecas académicas, lo que hace evidente la necesidad de indagar cómo se realiza este proceso de selección, suscripción o arrendamiento-adquisición e incorporación de los libros electrónicos en el tenor de los servicios bibliotecarios y de información de las instituciones de educación superior.

\section{Selección}

Toda selección de documentos, sean impresos, electrónicos o digitales, que se incorporan a los acervos de las bibliotecas, conlleva un conjunto de actividades que de manera global esboza un proceso en el cual intervienen varios profesionales; por tradición, los bibliotecarios hemos encabezado esas funciones. Aunque algunas de esas actividades también se aplican en el formato digital, es conveniente señalar que éste, por sí mismo, genera nuevas que es importante tener en cuenta: 
a) Libertad para seleccionar título por título.

b) Solicitar periodo de prueba del recurso.

c) Involucrar a las comunidades académicas y órganos colegiados establecidos para ello.

d) Revisar qué anota la literatura especializada sobre el título, modelo o colección.

e) Cotejar los títulos con los acervos impresos.

\section{Adquisición}

En torno a la adquisición del libro electrónico es pertinente señalar que lo primero que se modifica en relación con el formato impreso es el concepto de pertenencia del objeto en cuestión. Por tradición, al adquirir el libro, éste pasaba a formar parte de la colección de las bibliotecas y se reforzaba el sentido de propiedad de la obra física, aunque en términos de propiedad intelectual no necesariamente es así. En el entorno digital, las bibliotecas no tienen físicamente los documentos; ahora, en plena era de la digitalización, ofrecen el acceso o el arrendamiento del recurso por medio de licencias de acceso, compras por paquetes o colección, en donde el precio varía dependiendo del tamaño de la población de la institución, conocida por las siglas FTE (Full Time Equivalent Students). Mientras que para un lector en lo personal el precio es uno, y por lo general más bajo del costo del ejemplar impreso, para una institución o sistema bibliotecario el precio se incrementa porque se parte de la idea de que un mayor número de lectores hará uso de la obra.

Dado lo anterior, la fase de la negociación con el editor, proveedor o agregador de contenidos es determinante en el proceso para que, al final de esta etapa, prevalezca en ambas partes la impresión de ganar-ganar. En lo personal y profesional, desde 2002 he participado en diversas etapas de negociación con representantes de modelos internacionales de libros electrónicos, y a partir del diálogo, del intercambio de puntos de vista y de la exposición de necesidades, las instituciones de educación superior han obtenido óptimas condiciones para el acceso a destacados 
contenidos digitales académicos. Es por ello necesario refrendar la sensibilidad de los editores internacionales para que sus clientes queden satisfechos.

En el caso de las compras a perpetuidad, o por lo menos a largo plazo, se requieren mayores inversiones por parte de las instituciones, y en frecuentes ocasiones éstas carecen de esos montos económicos. Sin embargo, a mediano plazo se vislumbra que las organizaciones se verán en la necesidad de establecer partidas especiales para los contenidos digitales, o bien, incrementar sustancialmente las asignaciones tradicionales para los recursos de información digital.

Es oportuno señalar que las bibliotecas académicas siempre seleccionan los títulos de acuerdo con las peticiones de sus comunidades, o bien, con base en las bibliografías requeridas en sus planes o programas de estudio.

En el terreno de la industria editorial digital existen modelos que organizan los títulos en colecciones temáticas o retrospectivas. No está por demás reiterar la libertad que deberá prevalecer para que las bibliotecas en general realicen su selección título por título. Sin embargo, también hay que estar atento cuando la situación amerita la suscripción a una colección determinada, en la cual cada uno de los títulos que la integran corresponde efectivamente a las necesidades académicas de la institución. Dado lo anterior, resulta obligado que las políticas de desarrollo de colecciones consideren ambas situaciones.

En el caso de la UNAM, a partir de 2012 se estableció que las compras o suscripciones de libros electrónicos se realicen a través de la DGB, la cual emite los lineamientos para la adquisición de éstos a través del presupuesto asignado por la administración central.

\section{Organización}

La presencia del libro electrónico en las bibliotecas académicas se manifiesta de varias formas: la primera es con la incorporación de los registros bibliográficos en los catálogos en línea, lo cual 
implica solicitar al editor o proveedor el registro bibliográfico, por lo general en formato MARC; una segunda es a través de las plataformas de los propios editores, proveedores o de los agregadores de contenidos, y una tercera la constituyen los listados de los títulos electrónicos insertados en los sitios de Internet de las bibliotecas, o bien, los logotipos de los sellos editoriales. Se estima que deben ampliarse todas las opciones para la localización y recuperación de la información digital.

\section{Circulación}

Sobre el particular es necesario precisar que el concepto tradicional de préstamo, también se modifica en el ámbito digital de los servicios bibliotecarios y de información. Por lo general, la biblioteca coloca los anuncios en su sitio de Internet y, de acuerdo con el modelo de negocios seleccionado, el libro puede consultarse en pantalla en la modalidad de mono o multiusuario, o bien, se descarga el contenido del mismo a un equipo de cómputo en particular y, con base en las políticas de préstamo establecidas por las bibliotecas, podrá permanecer 1, 2 o 3 días y después de este periodo inhabilitarse debido a programas conocidos como Digital Rights Management (DRM).

Por otra parte, en algunas bibliotecas se ofrece el préstamo del dispositivo con el propósito de que el usuario se familiarice con dicha herramienta y entre en contacto con los contenidos digitales. Otra forma de circular los libros electrónicos se da a través de plataformas de acceso; en los Estados Unidos, una de las empresas con mayor presencia en este sentido es Overdrive. Este modelo figura en el espectro de contenidos digitales presente en la UNAM.

La circulación también se refiere a las acciones emprendidas por las bibliotecas para darles a conocer el material a sus comunidades. En este tenor se comprenden la impartición de talleres, la elaboración de pósters y el envío de correos electrónicos a las comunidades por medio de listas de interés, principalmente. 
En suma, los párrafos anteriores muestran múltiples acciones realizadas al interior de las instituciones de educación superior con el propósito de incorporar al libro electrónico en el tenor de los servicios bibliotecarios y de información.

Cada una de las instituciones anotadas instrumentaron estrategias diferentes para lograr su objetivo y en cada una participaron diferentes actores; sin embargo, en todas coinciden los sellos editoriales, los títulos, las colecciones y los modelos de negocios de dichos contenidos.

La revisión, análisis y reflexión de cada caso nos permitirá a corto plazo delinear un modelo para el desarrollo de colecciones de libros electrónicos para las instituciones de educación superior.

\section{REFERENCIAS BIBLIOGRÁFICAS}

Alonso-Arévalo, J., \& Cordón-García, J. (2010), "El libro electrónico ha llegado a las bibliotecas... y viene para quedarse", en: Mi biblioteca, 23, pp. 74-83. Disponible en: http://eprints.rclis.org/15373/1/ Quedarse.pdf

Alvite Díez, María Luisa y Blanca Rodríguez Bravo (2006), "Colecciones de libros electrónicos en las bibliotecas universitarias españolas", en: VIII Jornadas de Gestión de la Información, Madrid, 6-7 de noviembre (conferencia). Disponible en: http://eprints.rclis. org/8484/1/Sesion_3_comunicacion_1_Alvite.pdf

Armstrong, C., Fenton, R., Lonsdale, R., Stoker, D., Thomas, R., and Urquhart, C. (2001), A study of the use of Electronic Information Systems by Higher Education Students in the UK, Program, 35, pp 239-260.

Armstrong, C. J., Edwards, E., and Lonsdale, R. E. (2002), Virtually There: e-books in UK academic libraries, Program, 36, pp. 216-227. 
Clavero, Javier, Miguel Codina, Andrés Pérez y Marta Serrat Brustenga (2009), "Estudio de caso de servicio de préstamo de libros electrónicos", en: El profesional de la información, 18, (2), mar.abr., pp. 237-241.

Connaway, L., \& Wicht, H. L. (2007), "What happened to the e-book revolution?: The gradual integration of e-books into academic libraries", en: The Journal of Electronic Publishing, 10 (3). Disponible en: http://hdl.handle.net/2027/spo.3336451.0010.302.

Cordón García, José Antonio y Carlos A. Lopes (2012), "El libro electrónico: invarianzas y transformaciones", en: El profesional de la información, 21 (1), ene.-feb., pp. 83-90.

Dillon, Denis (2001), "E-books: the University of Texas experience, part 1", en: Library Hi Tech, 19 (2), pp. 113-124.

Hernández Salazar, Patricia; Nicholas David y Rowland, Ian (2009), "E-books access and use by the higher education community in the United Kingdom”, en: Revista Interamericana de Bibliotecología, jul.-dic., 32, (2), pp 13-58.

Merlo Vega, José Antonio y Angela Sorli Rojo (2000), "Bibliotecas digitales (1) colecciones de libros de acceso público", en: Revista española de documentación científica, 23, (1).

Moscoso, P. (2003), "La nueva misión de la biblioteca universitaria ante el Espacio Común de Enseñanza Superior”, en: Actas de las Jornadas Los Centros de Recursos para el Aprendizaje y la Investigación en los Procesos de Innovación Docente, Palma de Mallorca, 2003.

Pérez Arranz, Fernando y Purificación Moscoso (2007), "El libro electrónico y su incidencia en las bibliotecas universitarias y científicas españolas", en: Revista española de documentación Científica, 30 (3), jul.-sep., pp. 343-363. 
Perrone, Agnese (2009), "Electronic book collection development in Italy: a case study", en: IFLA Journal, 35 (4), pp 305-312.

Rodríguez Bravo, Blanca (2004), Evaluación del acceso y gestión de los libros electrónicos en las bibliotecas universitarias españolas, (fotocopias).

Safley, E. (2006), "Demand for e-books in an academic library", en: Journal of Library Administration, 45 (3/4), pp. 445-457.

Sandler, M., Armstrong, K. \& Nardini, B. (2007), "Market formation for e-books: Diffusion, confusion or delusion", en: The Journal of Electronic Publishing, 10 (3). Disponible en: http://hdl.handle. net/2027/spo.3336451.0010.310.

Universidad Nacional Autónoma de México (2012), Agenda estadística 2012, México: UNAM, Dirección General de Planeación (disco compacto).

Universidad Nacional Autónoma de México (2012), Memoria UNAM 2011, México: UNAM, Dirección General de Planeación (disco compacto). 


\title{
Fotografía digital: catalogación y metadatos para la biblioteca digital
}

\author{
ADRIANA MONROY MUÑOZ \\ Universidad Nacional Autónoma de México
}

\section{INTRODUCCIÓN}

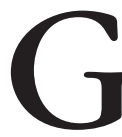

randes cambios se han experimentado en el ámbito de la organización de la información, algunos de ellos y las prácticas más relevantes al respecto han permitido la conformación de códigos y principios para la catalogación, lenguajes bibliotecológicos, estructuras de descripción, etcétera, que siguen teniendo injerencia en este momento. Ahora, la bibliotecología se encuentra ante el desafío de aplicar nuevos modelos para representar y organizar los recursos de información.

Si bien, durante un tiempo considerable, se catalogaron los recursos documentales de manera separada por tipo de soporte, la nueva estructura lleva a describir, vincular y a acceder a todo tipo de recursos y contenidos. Se espera que los registros resultantes sean parte esencial en la biblioteca y, dadas las características de los recursos digitales que se pretenden resaltar con el uso del nuevo, la biblioteca digital es el espacio ideal para permitir el acceso a esta información.

La fotografía, como sucede con otros recursos de información tales como grabaciones sonoras, libros, partituras, videograbaciones, revistas, mapas, etcétera, presenta una fuerte tendencia a publicarse en formato digital. Estas obras fueron reconocidas en 
primera instancia como disponibles en formatos electrónicos, pero más tarde han sido denominadas, poco a poco, como digitales y se fueron sumando a las colecciones de bibliotecas que contaban con ejemplares disponibles en medios impresos y analógicos.

Esta forma de publicación simultánea lleva a ampliar los alcances de las colecciones en las bibliotecas que anteriormente estaban centradas en conjuntos limitados de formatos, como lo señala la Association of College and Research Libraries (ACRL, 2012). La ACRL sostiene que la actual integración deberá tomar en cuenta los formatos digitales, los que tienen características multimedia y los formatos analógicos, pero también deberá darse prioridad a catalogarlos para contribuir a su acceso oportuno.

Con base en lo anterior, para abordar el tema de la organización de la información de la fotografía digital, en este trabajo se han tomado en cuenta dos perspectivas fundamentales. Se observa a la fotografía digital categorizada como un material gráfico, pero también tomando en cuenta aquellas características que se ajustan a la denominación de recurso electrónico. Derivado de las dos ópticas, se busca presentar la forma en que la fotografía digital debe ser descrita para incorporar adecuadamente los registros resultantes de la descripción en la biblioteca digital.

Para lograr lo anterior se revisó el contenido de una de las principales herramientas empleadas en la organización de la información, analizando las reglas e instrucciones que permiten describir la fotografía digital. De esta manera, la información presentada a través de este documento resume el resultado del análisis empleando las Reglas de catalogación angloamericanas, segunda edición revisada (RCA2r, 2004) en lo que corresponde a sus Capítulos 1, 4, 8 y 9.

Además, con el fin de obtener la representación del registro y relacionarlo a un proceso de automatización, o bien para prepararlo con la posibilidad de potenciar su disponibilidad a través de la Web, se usan tres elementos que refieren el resultado del análisis: las etiquetas correspondientes del formato MARC 21, el Núcleo de Dublín (DC) y la representación en RDF (Resource Description From work -Marco para la Descripción de Recursos) teniendo en 
cuenta que es un importante estándar para el intercambio de datos en la Web y para el desarrollo de la Web Semántica.

\section{LA FOTOGRAFÍA DIGITAL EN EL CONTEXTO DE LAS RCA2R}

La última edición vigente de las Reglas de catalogación angloamericanas (RCA), comúnmente conocida como RCA2r, contiene el Capítulo 8, dedicado a los Materiales Gráficos. En términos generales, este capítulo se usa en lo que corresponde a la catalogación descriptiva de la fotografía, con fundamento en que es un material visual opaco y con características bidimensionales.

Las RCA retoman, a su vez, lo establecido en la Descripción Bibliográfica Internacional Normalizada (ISBD) y el Capítulo de Materiales Gráficos lo hace también de la Descripción Bibliográfica Internacional Normalizada para materiales no librarios (ISBD NBM, 1993). Así, cuando la fotografía se encuentra en soportes analógicos como el vidrio, papel, negativo, diapositiva, etcétera, las reglas que comprenden la descripción de materiales gráficos se establecen en Capítulo 8. Por ello, en múltiples ocasiones se les ha llamado materiales no librarios, o también materiales especiales.

De las ISBD se han editado distintas ediciones y títulos dirigidos a recursos particulares de información, de las que se inició su publicación en 1974 hasta lograr generarse en 2007 la edición consolidada. Entre el inventario se encuentran las versiones publicadas en inglés y diversas traducciones, por mencionar algunas: ISBD (M) para publicaciones monográficas, ISBD (S) para publicaciones seriadas, ISBD (NBM) para materiales no librarios, ISBD (A) para publicaciones monográficas antiguas, ISBD (ER) para recursos electrónicos, etcétera.

Con respecto a las RCA, también surgieron las versiones en inglés y sus respectivas traducciones, que han incorporado los principios establecidos en las ISBD. Esto lleva a que cada nueva edición publicada, incluyendo la segunda edición revisada y ac- 
tualizada de las Reglas de catalogación angloamericanas (RCA2r), constituya una adhesión de las distintas ISBD a los capítulos que conforman su estructura.

Aunque en las RCA2r se han publicado actualizaciones dirigidas a la descripción de recursos electrónicos, recursos continuos y material cartográfico digital (RCA2r 2004), entre los rasgos más destacables, el Capítulo 8 no cuenta con instrucciones especiales vinculadas con la fotografía digital.

Para la catalogación de la fotografía, además de la aplicación del Capítulo 8 sobre Materiales gráficos, debe usarse el Capítulo 1, en el que se indican las Reglas generales para la descripción. Los dos capítulos serán la base fundamental en la catalogación si la fotografía es analizada como un material gráfico. De ahí deriva que los elementos descriptivos que la identifican estarán ordenados en siete de las ocho áreas catalográficas establecidas en las reglas generales:

1. Área de título y de la mención de responsabilidad.

2. Área de la edición.

3. Área de publicación, distribución, etcétera

4. Área de la descripción física.

5. Área de la serie.

6. Área de las notas.

7. Área del número normalizado y de las condiciones de disponibilidad.

El área tres denominada Área de los detalles específicos del material (o tipo de publicación) no es un área de uso validado con el Capítulo 8.

Sin embargo, la fotografía digital cuenta con características adicionales que llevan a considerar el uso de un nuevo capítulo. Se podrían consultar, por lo tanto, las reglas del Capítulo 8 y, además, las incluidas en el Capítulo 9 tomando en cuenta que el alcance de éste así lo permite:

El Capítulo 9 se usa para describir Recursos electrónicos “[...] que constan de datos (información que representa números, tex- 
to, gráficos, imágenes, mapas, imágenes en movimiento, sonidos, etcétera), programas (instrucciones, etcétera, que procesan datos para su uso), o combinación de datos y programas. Los recursos electrónicos incluyen a menudo componentes con características que se encuentran en diversas clases de materiales, por lo tanto, con frecuencia será necesario consultar otros capítulos." (RCA2r, 2004, p. 9-2 a 9-3). Es necesario agregar que en un recurso electrónico los datos y/o programas estarán codificados para ser manipulados mediante la computadora (RCA2r, 2004, p. D-9).

Las características de la fotografía digital en lo que corresponde a su identificación como material gráfico y su producción en un archivo electrónico han sido referidas en la literatura. De acuerdo con Lister (2004), la fotografía como imagen digital está involucrada fundamentalmente con dos desarrollos tecnológicos:

- La digitalización por medio de un escáner de las fotografías analógicas o el registro de la imagen por medio de una cámara digital.

- El uso de sistemas de procesamiento gráfico para la producción de imágenes de calidad fotográfica y la simulación en 3-D con fotografías.

La característica que tienen en común la fotografía análoga y la digital, también señalada por Lister, es que la imagen es captada por un lente óptico, pero se almacena en un material análogo con respecto a la primera, y en un archivo electrónico en la fotografía digital.

Así, los elementos descriptivos que la identifican como recurso electrónico estarían ordenados en ocho áreas catalográficas de uso específico con la aplicación del Capítulo 9:

1. Área de título y de la mención de responsabilidad.

2. Área de la edición.

3. Área de tipo y extensión del recurso

4. Área de publicación, distribución, etcétera.

5. Área de la descripción física. 
6. Área de la serie.

7. Área de las notas.

8. Área del número normalizado y de las condiciones de disponibilidad.

La segunda opción tiene validez y es plenamente aplicable en algunos recursos, como se muestra más delante. No obstante, hay que tener en cuenta las estrategias señaladas por bibliotecas con experiencia en el tema. Por ejemplo, la Library of Congress publicó en 2004 un documento que lleva por título Born digital photographs: cataloging samples digital (2004). En el texto se señala que las fotografías electrónicas tomadas con cámaras digitales a partir de la década de 1990, requieren ser catalogadas en forma equiparable a aquellas que se encuentran en papel, película, vidrio, metal y tela. Reconoce además que las dos variedades, pueden estar integradas en una colección digital de bibliotecas o archivos.

Para la descripción se plantean, entre las principales observaciones, las siguientes:

- La descripción debe realizarse como fotografías y no como archivos de computadora.

- La catalogación debe permitir visualizar datos como: fecha de captura, tipo de archivo electrónico, nombre del fotógrafo, entre otras informaciones de identificación.

- Será necesario adicionar en el campo de otros detalles físicos, en el área de la descripción física, el tipo de archivo en que está almacenada la imagen.

- Hay que adicionar al registro una dirección electrónica donde se pueda visualizar la imagen como colección o como documento individual.

- Se agregará, como otro punto de acceso dentro de los temas, el término Fotografía digital para facilitar la identificación y recuperación por parte del usuario. 


\section{PERFIL DE DESCRIPCIÓN PARA LA FOTOGRAFÍA DIGITAL CON RCA2R}

El asiento principal que hace referencia al fotógrafo es un elemento básico del registro bibliográfico. Los datos que se incluyen son: el nombre del autor y la función que desempeña respecto al contenido intelectual de la obra. Cabe anotar que, a efecto de aclarar los elementos que están incluidos en algunas áreas catalográficas, y en este caso respecto al asiento principal, se muestran ejemplos reales que describen fotografías digitales disponibles en Internet.

Ejemplo: Asiento principal para el fotógrafo

Fotografías digitales publicadas con información textual.

Perfil de descripción con RCA2r $r$

Asiento principal

Nombre, función $=$ fotógrafo

Waite, Charles Burlingme, fotógrafo

Para todas las áreas catalográficas se siguen las Reglas generales para la descripción contenidas en el Capítulo 1, pero existen precisiones en los Capítulos 4, 8 y 9 que resultan de la aplicación para la fotografía digital. Asimismo, se presentan ciertas variantes si el recurso de información se encuentra publicado, si es un material inédito y si existe información, textual o no, en la fuente de información.

Ejemplo: Área de título y mención de responsabilidad (Área 1)

\section{Fotografías publicadas con información textual}

Título asignado por el fotógrafo [DGM = diapositiva, gráfico, conjunto o recurso electrónico]: [otra información aclaratoria sobre el contenido] / fotógrafo, revelador, productor y patrocinador. Para recurso electrónico también se agregan otras menciones relacionadas con la creación del contenido del recurso Lobo mexicano [recurso electrónico]: canis lupus baileyi / [fotógrafo] José Ignacio Granados Peón

\section{Fotografías inéditas con información textual}

Título asignado por el fotógrafo [DGM = diapositiva, gráfico, conjunto o recurso electrónico]: [otra información aclaratoria sobre el contenido] / fotógrafo. Si el nombre o la firma están incompletos, se pueden completar. 
Debido a las características de la fotografía, en numerosas ocasiones, quien produce la fotografía tiende a capturar la imagen sin datos que vinculen al autor, el título designado por él, la fecha de la toma de la imagen, etcétera. Por ello, las RCA2r incluyen reglas dirigidas a resolver estas problemáticas. Principalmente se aplican dichas reglas en el Área 1 y en el Área de publicación, distribución, etcétera (Área 4). Para estos casos se registran los datos usando corchetes para indicar la información proporcionada por el catalogador.

Ejemplo: Registro del Área 1 y Área 4 sin información disponible en la fuente

\section{Fotografías publicadas sin información textual}

[Redactar un título breve que describa el contenido o por el que se conoce la colección, basado en el ítem o en una fuente de consulta] [DGM = diapositiva, gráfico, conjunto o recurso electrónico] : [fecha de toma, revelado o reproducción, diferente a la incluida en el área 4 y otra información aclaratoria del contenido] / no construir una mención, si es necesaria se usa una nota

[Lugar de publicación: Nombre del editor, distribuidor, etcétera Fecha aproximada de publicación, distribución, etcétera]

[España]: National Geographic España, [2012?]

\section{Fotografías inéditas sin información textual}

[Redactar un título breve que describa el contenido o asignar un título para tarjeta postal de acuerdo a las instrucciones de 4.1B2] [DGM: diapositiva, gráfico, conjunto o recurso electrónico]: [otra información aclaratoria sobre el contenido] / [fotógrafo. Si no tiene mención o firma, asignar el nombre si se conoce]

[Fecha de creación]

[s.t: : S. n], [2012]

Por otro lado, en el Área 4 sólo se registra la fecha si el material es inédito. En este elemento las RCA2r frecuentemente sólo permiten registrar la fecha considerando el año de publicación o producción, aunque existen variantes en fechas aproximadas, décadas aproximadas y periodos, entre otras.

No obstante, es recomendable para distinguir entre la variedad de obras generadas como fotografías digitales. Desde el análisis de este trabajo, se considera pertinente registrar la fecha de creación de la fotografía o de su publicación empleando ocho dígitos en la forma normalizada en el área de publicación; esto es, 
yyyymmdd. Aunque cabría la posibilidad de hacerlo en el Área 4, también se puede hacer en una nota; la nota prevista para ello se relaciona con la fecha del evento o toma. Además, se pueden agregar otras fechas útiles en el Área 4 para la identificación de la fotografía digital cuando se aplican las RCA2r para un recurso electrónico, tales como fecha de creación, actualización, modificación, compilación, etcétera.

Para la catalogación de recursos electrónicos disponibles en Internet, entidades catalográficas que cuentan con experiencia en el tema han hecho observaciones para facilitar la solución de problemas que suelen surgir en la catalogación de estos materiales. Con referencia al Área 3, se sugiere omitir la información, pues los datos previstos no ayudan a localizar e identificar el recurso. El Área 5 también es omitida del registro para un recurso de acceso remoto (Hsieh-Yee, 1997).

Resulta importante distinguir al recurso electrónico de otras variedades incluidas en las que se presentan textos, imágenes, información multimedia, etcétera. Por ello, el Área 5 será un elemento clave en la identificación de una fotografía digital. Aunque la sugerencia lleva a omitir el área para recursos remotos, debiera ser modificado el criterio para una fotografía digital. Con ello, y tomando en cuenta el análisis de los capítulos de RCA2r, se debería incluir en esta área.

Ejemplo: Registro del Área 5 para una fotografía digital disponible en Internet

\section{Fotografías digitales publicadas con información textual}

Extensión y designación específica (i. e. procesos fotográfico): otros detalles físicos como tipo de archivo, presencia de color, etcétera; las dimensiones de alto $\mathrm{X}$ ancho en $\mathrm{cm}$. para una fotografía digital se omiten 1 fotografía digital : JPEG, color

El Área de notas está compuesta por una gran variedad de información. En ella se incluye información no registrada en las áreas que le anteceden, pero también información específica que permita crear un registro con mayor detalle. Las bibliotecas deben decidir el nivel de detalle para la descripción en el registro 
bibliográfico de la fotografía digital, y ello influirá en el nivel de detalle de las notas.

Si tomamos en cuenta que una fotografía descrita como material gráfico usa notas que no se mencionan en el Capítulo 9, éstas podrían sumarse a las que se registran en la descripción como recurso electrónico. Cuando se describe un recurso electrónico se registran otras notas, algunas de ellas relacionadas principalmente con la disponibilidad de información a través de Internet. Las de aplicación para material gráfico son:

\begin{tabular}{|l|}
\hline \multicolumn{1}{|c|}{ Área de notas } \\
\hline Esbozo histórico o historia administrativa \\
\hline Donante, propietario anterior, propietario o custodio legal \\
\hline Historia de la propiedad y custodia. Historia del ítem \\
\hline Información sobre financiamiento o auspicios del proyecto \\
\hline Fecha, hora y lugar de un evento, creación, toma, etcétera \\
\hline Publicaciones sobre los materiales descritos \\
\hline Condiciones de uso y reproducción \\
\hline Citas o referencias bibliográficas \\
\hline Otros formatos disponibles \\
\hline Organización y arreglo de los materiales \\
\hline Localización de originales o duplicados \\
\hline Notas “Con" \\
\hline Versión original \\
\hline Exposiciones \\
\hline Premios \\
\hline
\end{tabular}

Con base en lo expuesto, el registro bibliográfico completo para la fotografía digital empleando las dos perspectivas, esto es, como material gráfico y como recurso electrónico, quedará con la estructura que muestra la siguiente tabla: 
Fotografía digital: catalogación y metadatos...

\section{Fotografías digitales publicadas con información textual}

Perfil de descripción con RCA2r r

Asiento principal

Nombre, función = fotógrafo

Área de título y de la mención de responsabilidad

Título asignado por el fotógrafo [DGM = diapositiva, gráfico, conjunto o recurso electrónico]: [otra información aclaratoria sobre el contenido] / fotógrafo, revelador, productor y patrocinador. Para recurso electrónico también se agregan otras menciones relacionadas con la creación del contenido del recurso

Área de la edición

Edición, versión, nivel, etcétera

Área de tipo y extensión del recurso

Información omitida para recursos electrónicos disponibles en Internet

Área de publicación, distribución, etcétera

Lugar de publicación: Nombre del editor, distribuidor, etcétera. Fecha de publicación, distribución, creación, actualización, modificación, compilación, etcétera. Sólo se usa en esta área, la fecha de creación para el material inédito

Área de la descripción física

Área omitida para recursos electrónicos disponibles en Internet

Extensión y designación específica como fotografía digital: otros detalles físicos como tipo de archivo, presencia de color, etcétera; las dimensiones de alto $X$ ancho en $\mathrm{cm}$. para una fotografía digital se omiten

Área de la serie

Serie y número dentro de la serie

Área de las notas

Fuente del título propiamente dicho. Nota obligatoria

Naturaleza y alcance

Requerimientos del sistema

Forma de acceso

Lengua y escritura

Variantes del título

Créditos de creación y producción

Edición e historia

Publicación, distribución, etcétera

Nota de medio físico y material complementario

Tesis

Público al que está destinado el ítem

Otros formatos disponibles

Restricciones de acceso

Términos de uso, reproducción y URL para el acceso a la información sobre los términos de uso

Sumario

Contenido

Números importantes del ítem, diferentes al ISBN e ISSN

Nota de medio físico y material complementario

Citas o referencias a la obra o colección en que se publica el recurso visual

Esbozo histórico, biográfico o historia administrativa

Información sobre la adquisición, donante, propietario o custodio legal

Historia de la propiedad y custodia. Historia del ítem

Organización y arreglo de los materiales 
Biblioteca Digital Académica en Bibliotecología...

\begin{tabular}{|l|}
\hline Información sobre financiamiento o auspicios del proyecto \\
Fecha, hora y lugar de un evento, creación, toma, etcétera \\
Publicaciones sobre los materiales descritos \\
Exposiciones \\
Premios \\
Localización geográfica y URL para la localización geográfica \\
Localización del original: Custodio, Dirección postal, País y Dirección electrónica \\
URL \\
Notas locales \\
\hline Área del número normalizado y de las condiciones de disponibilidad \\
ISBN \\
\hline Temas \\
Tema - Subencabezamiento \\
Tema - Subencabezamiento \\
\hline Secundarias \\
Encabezamiento secundario
\end{tabular}

\section{PERFIL DE CODIFICACIÓN PARA LA FOTOGRAFÍA DIGITAL EN FORMATO MARC21}

Gorman afirma que las ISBD y las RCA se crearon teniendo objetivos distintos al impacto real que ahora tienen en la normalización bibliográfica internacional. Este mismo señalamiento lo hace del formato MARC, pero sostiene que debe ser diferenciado de la catalogación y los metadatos. Aclara que MARC es:

una norma para la estructuración de los datos, es decir, es una forma de almacenar y trabajar con los datos que se han obtenido de acuerdo a unas normas de contenido como las reglas de catalogación y otras similares [es justamente] la manera de codificar los resultados del proceso de catalogación (Gorman, 2003).

Actualmente, MARC 21 consiste en cinco formatos específicos que son referidos ampliamente como "[...] standards for the representation and communication of bibliographic and related information in machine-readable form" (MARC Standards, 2012). Esto es, normas para la representación y la comunicación de la información bibliográfica e información relacionada en forma 
legible por máquina. En su documentación, figura el formato bibliográfico y los empleados para autoridades, fondos, clasificación e información de la comunidad MARC.

De esta forma, podemos asegurar que la normativa se formalizó a través de códigos y principios para la catalogación, a la que se sumaron, con objeto de automatizar y producir los registros bibliográficos, los formatos para la codificación de información bibliográfica y de autoridad. Se añade al registro bibliográfico y el resultado de la indización empleando los lenguajes documentales controlados, los sistemas bibliotecológicos de clasificación, las listas de encabezamientos de materia y los tesauros.

Tomando en cuenta lo anterior, se presenta el resultado de la descripción para la fotografía digital en el perfil de codificación empleando MARC21:

\begin{tabular}{|l|l|}
\hline \multicolumn{2}{|c|}{$\begin{array}{c}\text { Fotografías digitales publicadas con información textual } \\
\text { Perfil de codificación en formato MARC21 }\end{array}$} \\
\hline 020 & |a ISBN \\
\hline $1 X X$ & |a Asiento principal \\
\hline 245 & $\begin{array}{l}\text { a Título asignado por el fotógrafo |h [DGM = diapositiva, gráfico, conjunto o recurso electrónico] : |b } \\
\text { [otra información aclaratoria sobre el contenido] / |c fotógrafo, revelador, productor y patrocinador. } \\
\text { Para recurso electrónico también se agregan otras menciones relacionadas con la creación del } \\
\text { contenido del recurso }\end{array}$ \\
\hline 250 & |a Edición, versión, nivel, etcétera. \\
\hline 256 & |a Información omitida para recursos electrónicos disponibles en Internet \\
\hline 260 & $\begin{array}{l}\text { |a Lugar de publicación : |b Nombre del editor, distribuidor, etcétera, |c Fecha de publicación, distri- } \\
\text { bución, creación, actualización, modificación, compilación, etcétera }\end{array}$ \\
\hline 300 & [ |a|b|c y |d Área omitida para recursos electrónicos disponibles en Internet ] \\
\hline 300 & $\begin{array}{l}\text { |a Extensión y designación específica como fotografía digital : |b otros detalles físicos como tipo de } \\
\text { archivo, presencia de color, etcétera; las dimensiones de alto X ancho en cm. para una fotografía } \\
\text { digital se omiten }\end{array}$ \\
\hline 490 & |a Serie \\
\hline 588 & Notas \\
\hline 516 & |a Fuente del título propiamente dicho \\
\hline 538 & |a Naturaleza y alcance \\
\hline 538 & |a Requerimientos del sistema \\
\hline
\end{tabular}


Biblioteca Digital Académica en Bibliotecología...

\begin{tabular}{|c|c|}
\hline 516 & |a Tipo y extensión del recurso \\
\hline 546 & |a Lengua y escritura \\
\hline 500 & |a Variantes del título \\
\hline 508 & |a Créditos de creación y producción \\
\hline 534 & |a Edición e historia \\
\hline 500 & |a Publicación, distribución, etcétera \\
\hline 340 & la Nota de medio físico y material complementario \\
\hline 502 & la Tesis \\
\hline 521 & |a Público al que está destinado el ítem \\
\hline 530 & |a Otros formatos disponibles \\
\hline 506 & |a Restricciones de acceso \\
\hline 540 & |a Términos de uso y reproducción |u url para el acceso a la información sobre los términos de uso \\
\hline 520 & la Sumario \\
\hline 505 & |a Contenido \\
\hline 515 & |a Números importantes del ítem, diferentes al isbn e issn \\
\hline 340 & la Nota de medio físico y material complementario \\
\hline 510 & |a Citas o referencias a la obra o colección en que se publica el recurso visual \\
\hline 545 & |a Esbozo histórico, biográfico o historia administrativa \\
\hline 541 & |a Información sobre la adquisición, donante, propietario o custodio legal \\
\hline 561 & la Historia de la propiedad y custodia. Historia del ítem \\
\hline 351 & |a Organización y arreglo de los materiales \\
\hline 536 & |a Información sobre financiamiento o auspicios del proyecto \\
\hline 518 & la Fecha, hora y lugar de un evento, creación, toma, etcétera. \\
\hline 581 & |a Publicaciones sobre los materiales descritos \\
\hline 585 & la Exposiciones \\
\hline 586 & a Premios \\
\hline 522 & |a Localización geográfica |6 Link para la localización geográfica \\
\hline 535 & |a Localización del original, Custodio |b Dirección postal |c País |d Dirección \\
\hline 85640 & |u url \\
\hline $59 X$ & la Notas locales \\
\hline $65 X$ & |a Temas |_Subencabezamiento \\
\hline $7 X X$ & |a Encabezamiento secundario \\
\hline
\end{tabular}




\section{Ejemplo: Registro bibliográfico de una fotografía publicada en Internet. Catalogada y registrada con el perfil de codificación en formato MARC21}

\begin{tabular}{|c|c|}
\hline \multicolumn{2}{|r|}{$\begin{array}{l}\text { Fotografías digitales publicadas con información textual } \\
\text { Perfil de codificación en formato MARC21 }\end{array}$} \\
\hline $1 X X$ & |a Obregón Vázquez, Carlos Eduardo, |e fotógrafo \\
\hline 245 & |a Ocelote |h [recurso electrónico] : |b Leopardus pardalis / |c Carlos Eduardo Obregón Vázquez \\
\hline 260 & |a México : |b CONABIO, |c [2012?] \\
\hline 300 & |a 1 fotografía digital : |b JPEG, col. \\
\hline \multirow[t]{2}{*}{490} & la Mosaico natura México \\
\hline & Notas \\
\hline 588 & |a Título tomado del Banco de imágenes CONABIO \\
\hline 538 & |a Forma de acceso: World Wide Web \\
\hline 516 & |a Tamaño del archivo: 400, 600 y 800 \\
\hline 508 & $\begin{array}{l}\text { la Alojamiento del contenido en el Banco de imágenes de la Comisión Nacional para el Conoci- } \\
\text { miento y Uso de la Biodiversidad }\end{array}$ \\
\hline 5061 & $\begin{array}{l}\text { |a Las imágenes bajo la resolución del portal pueden utilizarse libremente, sin fines de lucro |c El } \\
\text { uso con fines de lucro y/o en alta resolución requiere } \\
\text { autorización de la CONABIO }\end{array}$ \\
\hline 540 & $\begin{array}{l}\text { la Protegida por la Ley Federal del Derecho de Autor |c Uso bajo licencia Creative Commons : } \\
\text { Atribución-NoComercial-Compartirlgual }\end{array}$ \\
\hline 520 & |a Mamífero carnívoro. Especie en riesgo en México nom-059_Ecol-2001 \\
\hline 541 & |a Donación \\
\hline 535 & $\begin{array}{l}\text { la Custodio CONABIO } \\
\text { |c México }\end{array}$ \\
\hline 85640 & |u * Ver url en las referencias bibliográficas (Obregón Vázquez 2012?) \\
\hline $65 X$ & |a Temas |_Subencabezamiento \\
\hline
\end{tabular}


Ejemplo: Registro bibliográfico de una fotografía en archivo digital, tomada de una vista estereoscópica. Catalogada y registrada con el perfil de codificación en formato MARC21

\begin{tabular}{|l|l|}
\hline \multicolumn{2}{|c|}{$\begin{array}{c}\text { Fotografías digitales de acceso local con información textual } \\
\text { Perfil de codificación en formato MARC21 }\end{array}$} \\
\hline 1 XX & |a Avilés Serna, Ignacio, |e fotógrafo \\
\hline 245 & |a En la estación de Xico F.C.S. Rafael |h [recurso electrónico] : / |c Ignacio Avilés Serna \\
\hline 256 & |a Datos electrónicos (1 archivo : 192 KB) \\
\hline 260 & |a 1920 \\
\hline 300 & |a 1 fotografía : |b digital, jpeg, sepia \\
\hline 588 & Notas \\
\hline 534 & |a Título tomado del ítem \\
\hline 530 & |a Imagen digital del ítem original: 1 estereografía : positivo en vidrio, sepia \\
\hline 5061 & $\begin{array}{l}\text { |a Soporte en vidrio de la vista estereoscópica. Acceso restringido } \\
\text { |a Es necesario solicitar permiso de reproducción al custodio legal } \\
\text { |c Sólo se puede consultar en formato digital debido a la fragilidad del positivo en vidrio y por }\end{array}$ \\
\hline 5401 & $\begin{array}{l}\text { |a Se aplican restricciones para el acceso y reproducción de acuerdo al Reglamento del Archivo } \\
\text { General de la Nación y las Disposiciones para la Consulta de los Acervos Documentales, Re- } \\
\text { glamento Interior de la Secretaría de Gobernación, Ley Federal de Transparencia y Acceso a la } \\
\text { Información Pública Gubernamental y su Reglamento y la Ley General de Bienes Nacionales }\end{array}$ \\
\hline 515 & |a Vista estereoscópica numerada por el fotógrafo con el no. 319A \\
\hline 518 & |a Fecha de la toma registrada por el fotógrafo: 19200905 \\
\hline 535 & |a Custodio: Archivo General de la Nación, Centro de Información Gráfica, Fototeca, |c México \\
\hline $65 X$ & |a Temas |_ Subencabezamiento \\
\hline
\end{tabular}

\section{METADATOS DE DESCRIPCIÓN PARA LA FOTOGRAFÍA DIGITAL}

Se reconoce que es necesario retomar los avances generados respecto a las nuevas formas de representar la información en la Web. A partir de que los recursos de información comienzan a ser desarrollados, publicados y transmitidos usando la Web, el ámbito bibliotecario se enfrenta a grandes cambios. La responsabilidad del bibliotecario de organizar y proveer acceso a otros 
materiales, incluyendo recursos como las bases de datos de texto completo, libros electrónicos, índices electrónicos, blogs, materiales de archivo, etcétera, remite a mejorar las prácticas en la catalogación y al uso de metadatos (Alexander, 2008).

En el trascurso de las últimas décadas, se agregaron a la teoría catalográfica normas en materia tecnológica, metadatos y modelos de descripción, entre otros elementos. Con ellos se busca formar una plataforma adecuada para el control, organización y recuperación de la información. Además se pretende optimizar el intercambio de información bibliográfica normada entre las bibliotecas y otras unidades de información.

Los metadatos y la catalogación son dos temas sobre los que se siguen discutiendo sus alcances y, sobre todo, la forma en que se distinguen cada uno de ellos. En este sentido, cabe mencionar lo resaltado por Weber y Austin (2004) ante la descripción de recursos electrónicos, digitales y otros medios de información. Advierten que los términos catalogación y metadatos son usados en la misma medida. En algunos casos, cuando se refieren al empleo de metadatos, indudablemente se han usado sólo registros MARC en lugar de crear registros mediante MODs o con el Núcleo de Dublín.

Lo cierto es que en este momento se requiere mayor énfasis en el catálogo para hacer la descripción de recursos digitales y la evolución de formas alternativas para la recuperación de información cuando se emplea la red. Esto lleva a incorporar nuevas prácticas para describir los recursos de información y sus distintas manifestaciones, y a establecer relaciones entre los recursos y entre las entidades responsables del contenido intelectual.

La biblioteca ahora digital ha comenzado la transición a otra etapa relacionada prácticamente con el acceso a la Web. El progreso es, en parte, el resultado de los catálogos de nueva generación desarrollados en algunos sistemas integrales de automatización. Entre las opciones ofrecidas como alternativas, el enfoque mira hacia la generación de plataformas para los nuevos servicios bibliotecarios, el apoyo integral en la gestión de colecciones, el acceso mediante herramientas integrales a todo tipo de materiales de la biblioteca y al incremento de vínculos para el acceso a 
recursos electrónicos y digitales incluidos en las descripciones tanto de registros bibliográficos o por metadatos.

Hace más de una década, se planteó mejorar el catálogo empleando los principios internacionales para la catalogación actualizados: la versión MARC en esquema XML, los esquemas de metadatos, el Núcleo de Dublin, etcétera (Gorman 2000). Ahora estamos en el momento de ocuparnos de ello.

Existe una amplia gama de esquemas de metadatos empleados en la descripción, y determinados esquemas son usados especialmente para materiales gráficos. Entre ellos destacan: las $\mathrm{Ca}$ tegories for the Description of Works of Art (CDWA), el Encoded Archival Description (EAD), las Core Categories de la Visual Resources Association (VRA) y el Núcleo de Dublin (Descriptive Metadata..., 2005).

Con el fin de ejemplificar el uso de metadatos en esta investigación, se retoma principalmente lo planteado por Mini, U., Baby M. D. \& Poulose Jacob, K. (2006), Foulonneau \& Rilley (2008) y Kapidakis (2011). Con ello se decidió emplear en la ejemplificación el Núcleo de Dublín en combinación con la representación en RDF con el objetivo de validar los registros para la Web Semántica o cualquier otro esquema de metadatos que utilice sintaxis xml.

Mini, U., Baby M. D. \& Poulose Jacob, K. (2006) refieren que, en la construcción de la Web Semántica, juegan un papel muy relevante el eXtensible Markup Language (XML) y el Resource Description Framework (RDF). XML permite a los creadores de contenido etiquetar la información y, a la vez, RDF se usa para describir los datos mediante una sintaxis estándar y estructurarlos para facilitar la interoperabilidad entre las representaciones de los recursos en la Web.

Foulonneau y Rilley (2008) mencionan que DC es un estándar de metadatos descriptivos que puede ser empleado con cualquier tipo de recurso y se ha generalizado su uso en el sector del patrimonio cultural. Kapidaski agrega que estos metadatos permiten aumentar la interoperabilidad entre los registros, ya que DC se puede utilizar como un esquema universal sencillo y pueden combinarse los metadatos con otras colecciones. Estas 


\section{características serán sumamente relevantes en la conformación de la biblioteca digital y la integración de las descripciones de la fotografía digital en ella.}

Ejemplo: Representación en el Núcleo de Dublín de una fotografía en archivo digital, tomada de una vista estereoscópica

Representación en el Núcleo de Dublín de una fotografía en archivo digital

$<$ dc:title>Estación del F.C. Interoceánico, Sn. Lázaro, México</dc:title>

$<\mathrm{dc}$ :creator $>$ Avilés Serna, Ignacio, fotógrafo </dc:creator $>$

$<$ dc:subject>Railroads--Mexico--History</dc:subject>

$<$ dc:subject>Stereographs--1900-1920</dc:subject>

$<$ dc:description>Imagen digital del ítem original: 1 estereografía : positivo en vidrio, byn</dc:description>

$<$ dc:description>Toma registrada por el fotógrafo de fecha $19200808</ d c:$ description>

$<$ dc:date $>1920-08-08</$ dc: date $>$

$<$ dc:type $>$ Image $</$ dc:type $>$

$<$ dc:format>Image/JPEG $</$ dc:format $>$

$<$ dc:rights>Se aplican restricciones para el acceso y reproducción de acuerdo al Reglamento del Archivo

General de la Nación y las Disposiciones para la Consulta de los Acervos Documentales, Reglamento

Interior de la Secretaría de Gobernación, Ley Federal de Transparencia y Acceso a la Información Pública

Gubernamental y su Reglamento y la Ley General de Bienes Nacionales</dc:rights>

$<$ dc:rights>Sólo se puede consultar en formato digital debido a la fragilidad del positivo en vidrio y por ser

pieza única</dc:rights>

Ejemplo: Representación en el Núcleo de Dublín (extendido) de una fotografía en archivo digital, tomada de una vista estereoscópica

Representación en el Núcleo de Dublín (extendido) de una fotografía en archivo digital

$<$ dc:title>Estación del F.C. Interoceánico, Sn. Lázaro, México</dc:title>

$<\mathrm{dc}$ :creator>Avilés Serna, Ignacio, fotógrafo </dc:creator>

$<$ dc:subject xsi:type="dcterms:LCSH">Railroads--Mexico--History</dc:subject>

$<$ dc:subject xsi:type="dcterms:TGM">Stereographs--1900-1920</dc:subject>

$<\mathrm{dc}$ :description>Imagen digital del ítem original: 1 estereografía : positivo en vidrio, byn</dc:description>

$<$ dc:description>Toma registrada por el fotógrafo de fecha 19200808</dc:description>

$<$ dcterms:created xsi:type="dcterms:W3cdtf">1920-08-08</dcterms:created>

$<$ dc:type xsi:type="dcterms:dcmitype">Image</dc:type>

$<$ dc:format>Image/jpeg</dc:format>

$<$ dc:rights >Se aplican restricciones para el acceso y reproducción de acuerdo al Reglamento del Archivo General de la Nación y las Disposiciones para la Consulta de los Acervos Documentales, Reglamento Interior de la Secretaría de Gobernación, Ley Federal de Transparencia y Acceso a la Información Pública Gubernamental y su Reglamento y la Ley General de Bienes Nacionales</dc:rights> $<\mathrm{dc}$ :rights >Sólo se puede consultar en formato digital debido a la fragilidad del positivo en vidrio y por ser pieza única</dc:rights> <dcterms:provenance>Localización del original: AGN, Centro de Información Gráfica, Fototeca</ dcterms:provenance>

$<$ dcterms:provenance>Organización en el AGN: Archivo Fotográfico Ignacio Avilés. Sub-Fondo Vistas estereoscópicas</dcterms:provenance $>$ 
Biblioteca Digital Académica en Bibliotecología...

\begin{tabular}{|c|}
\hline Representación en el RDF/XML de una fotografía en archivo digital \\
\hline $\begin{array}{l}<\text { <xml version="1.0"?> } \\
\text { <dff:RDF xmlns:rdf="http://www.w3.org/1999/02/22-rdf-syntax-ns\#" } \\
\text { xmlns:dc="http://purl.org/dc/elements/1.1/"> } \\
\text { <rdf:Description rdf:about="http://www.w3.org/"> } \\
<\text { <c:title>Estación del F.C. Interoceánico, Sn. Lázaro, México</dc:title> } \\
\text { <dc:creator>Avilés Serna, Ignacio, fotógrafo </dc:creator> } \\
\text { <dc:subject>Railroads--Mexico--History</dc:subject> } \\
\text { <dc:subject>Stereographs--1900-1920</dc:subject> } \\
\text { <dc:description>Imagen digital del ítem original: } 1 \text { estereografía : positivo en vidrio, byn</dc:description> } \\
\text { <dc:description>Toma registrada por el fotógrafo de fecha 19200808</dc:description> } \\
<\text { dc:date>1920-08-08</dc:date> } \\
<\text { dc:type>Image</dc:type> } \\
<\text { dc:format>Image/JPEG</dc:format> } \\
<\text { dc:rights>Se aplican restricciones para el acceso y reproducción de acuerdo al Reglamento del Archivo } \\
\text { General de la Nación y las Disposiciones para la Consulta de los Acervos Documentales, Reglamento In- } \\
\text { terior de la Secretaría de Gobernación, Ley Federal de Transparencia y Acceso a la Información Pública } \\
\text { Gubernamental y su Reglamento y la Ley General de Bienes Nacionales</dc:rights> } \\
<\text { dc:rights> Sólo se puede consultar en formato digital debido a la fragilidad del positivo en vidrio y por ser } \\
\text { pieza única </dc:rights> } \\
</ \text { rdf:Description> } \\
</ \text { rdf:RDF> }\end{array}$ \\
\hline
\end{tabular}


Ejemplo: Visualización gráfica del modelo RDF/XML de una fotografía en archivo digital, tomada de una vista estereoscópica. De uso en la Web Semántica

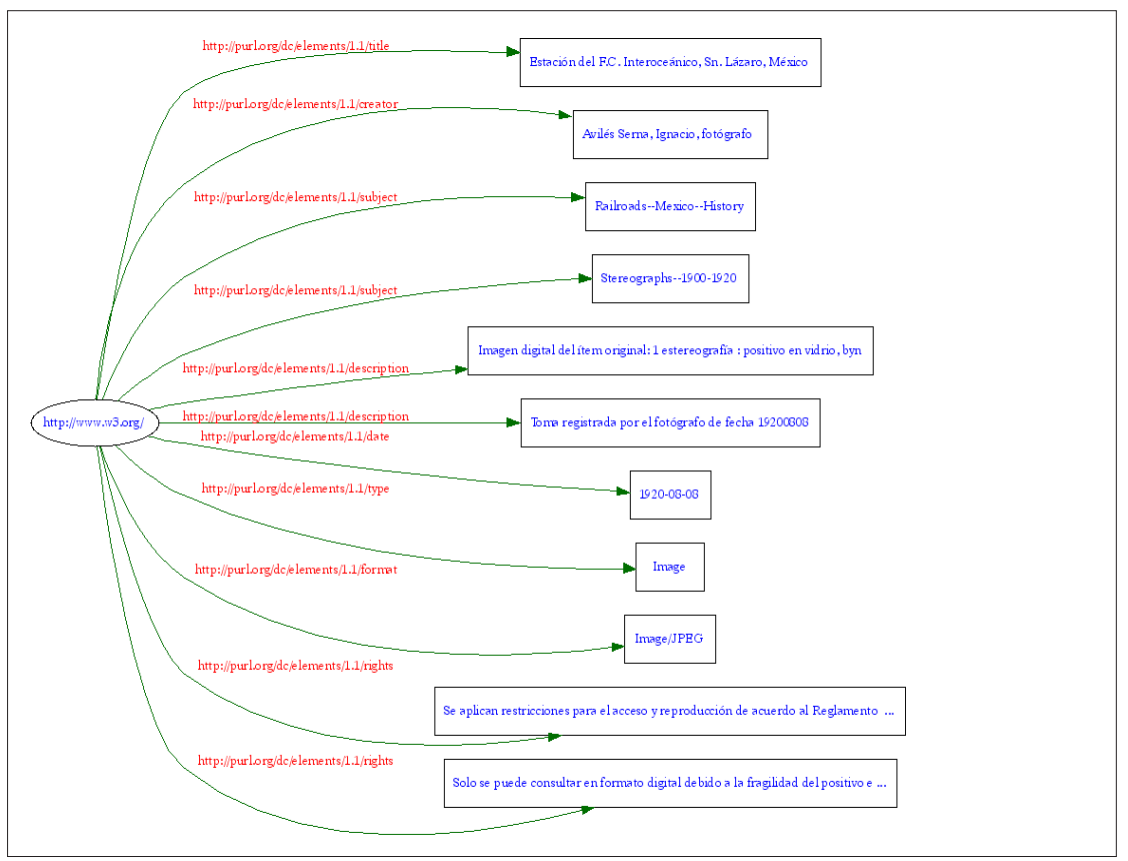

\section{CONCLUSIONES}

Es sumamente relevante que se encuentre actualizada la normatividad que rige los actuales procesos de catalogación y la organización de la información. Sin esa actualización, la publicación de recursos de información puede imponerse y causar estragos en la disponibilidad de información que requieren las bibliotecas actuales.

La biblioteca digital es un ámbito ideal en donde pueden incorporarse los recursos de información digitales, necesarios para las necesidades actuales, pero también los registros referenciales 
de las colecciones analógicas; para ello, las colecciones deberán de estar debidamente organizadas.

La fotografía digital descrita desde el punto de vista del recurso digital puede ser aprovechada como cualquier otro recurso impreso o digital que forme parte de estas colecciones. Será mucho más adecuado si se trabaja con las nuevas formas de representar la información. Con miras a lograrlo, tenemos que poner a prueba las nuevas formas de representación para actualizar la biblioteca y enfrentar otras necesidades de información a las que no estábamos acostumbrados.

Queda pendiente la implementación del código RDA: resources description \& access (2011) e identificar los atributos para describir los materiales especiales o cualquier tipo de contenido y medio, así como probar su efectividad para la descripción de las obras y sus diversas manifestaciones, incluyendo la fotografía analógica y la digital.

\section{AGRADECIMIENTOS}

Esta investigación recibe apoyo financiero como Becaria de CONACyT a través del Doctorado Bibliotecología y Estudios de la Información (Programa de Fomento, Formación, Desarrollo y Vinculación de Recursos Humanos de Alto Nivel del CONACyT). Además, forma parte de las actividades como integrante del grupo para el desarrollo del Programa UNAM-DGAPA-PAPITT IT 400312.

\section{REFERENCIAS BIBLIOGRÁFICAS}

Alexander, Mary S. (2008), "Core cataloging and metadata standards and best practices", pp. 63-64, en Science \& technologies libraries, (2008), Vol. 28, Núm. 1-2. 
American Library Association. Association of College and Research Libraries (2012), Guidelines for media resources in academic libraries [en línea], prepared by the ACRL Guidelines for Media Resources in Academic Libraries Task Force, Chicago, Ill, American Library Association, Association of College and Research Libraries. Disponible en: http://www.ala.org/acrl/standards/mediaresources (Consulta: agosto de 2012).

Born digital photographs: cataloging samples [en línea] (2004), Prints \& Photographs Division, Library of Congress, Washington, D. C.: Library of Congress. Disponible en: http://www.loc.gov/ rr/print/tp/Born\%20Digital\%20Photographs.pdf, 2 p. (Consulta: agosto de 2012).

Descriptive Metadata Guidelines for $R L G$ Cultural Materials, Mountain View, Calif.: RLG, 2005, 64 p. Disponible en: www.oclc.org/ research/activities/past/rlg/culturalmaterials/RLG_desc_metadata.pdf (Consulta: mayo de 2012).

Foulonneau, M \& Rilley, J. (2008), Metadata for digital resources: implementation, systems design and interoperability, Oxford: Chandos Publishing, pp. 21, Chandos information professional series.

Gorman, Michael (2003), "Control o caos bibliográfico: un programa para los servicios bibliográficos nacionales del siglo XXI", en: Anales de documentación [en línea], (2003), Núm. 6. pp. 277-288. Disponible en: http://www.redalyc.org/redalyc/pdf/635/63500618. pdf (Consulta: agosto de 2012).

Gorman, Michael (2000), "From card catalogues to Webpacs", en: Conference on Bibliographic Control for the New Millennium [en línea]: Washington, D.C., November 15th 2000. Disponible en: http://www.loc.gov/catdir/bibcontrol/gorman_paper.html (Consulta: mayo de 2012). 
Hsieh-Yee, Ingrid (1997), Modificaciones a las Reglas de catalogación y la infraestructura de OCLC para una organización efectiva de los recursos de Internet [en línea] / tr. por Filiberto Felipe Martínez Arellano, [s.l.: s.n.]., Originalmente publicado en: Proceedings of the OCLC Internet Cataloging Colloquium, San Antonio, Texas, January 1996, Título original: Modifying cataloging practice and OCLC infrastructure for effective organization of Internet resources. Disponible en http://www.uv.es/ fgines/modificaciones.htm (Consulta: agosto de 2012).

ISBD (NBM) Descripción bibliográfica internacional normalizada para materiales no librarios (1993), Recomendada por el Comité de Revisión de las ISBD; aprobada por el Comité Permanente de la Sección de Catalogación de la IFLA; tr. y ejemplos realizados por María José Perez Tapia y Carmen Ramos Fajardo, Ed. rev. Madrid, Anabad: Arco Libros, 1993. XII, 122 p.

Kapidakis, S. (2011), "Emerging challenges of the digital information", pp. 141- 156, en: E-publishing and digital libraries: legal and organizational issues I, Iglezakis, T.-E Sunodinou \& S. Kapidakis, ed. Hershey: Information Science Reference.

Lister, Martin (2004), "Photography in the age of electronic imaging", en: Photography: a critical introduction, ed. by Liz Wells, 3rd ed. London: Routledge.

MARC standards [en línea] (2012), Library of Congress, Network Development and MARC Standards Office, Washington, D. C.: The Library of Congress. Disponible en: http://www.loc.gov/marc/ (Consulta: mayo de 2012). 
Mini, U., Baby M. D. \& Poulose Jacob, K. (2006), "Knowledge representation through Semantic Web: an architectural overview", pp. 480-485, en 4th International Convention CALIBER-2006, Gulbarga, 2-4 February, 2006 [en línea], Ahmedabad, [Gujarat, India]: INFLIBNET. Disponible en: http://ir.inflibnet.ac.in/dxml/bitstream/ handle/1944/1099/54.pdf?sequence=1 (Consulta: agosto de 2012).

Monroy Muñoz, Adriana (2010), "La catalogación normalizada de la fotografía: análisis y propuesta”, h. 55-116, en: Identificación de la fotografía como patrimonio documental a través de la catalogación, México: la autora, 2010, Tesis (Maestra en Bibliotecología y Estudios de la Información).

Obregón Vázquez, Carlos Eduardo, fotógrafo (2012), Ocelote [recurso electrónico]: Leopardus pardalis, 1 fotografía digital: JPEG, col. En Banco de imágenes [en línea] ,Comisión Nacional para el Conocimiento y Uso de la Biodiversidad, México: COnABIo. Disponible en http://bdi.conabio.gob.mx/fotoweb/Preview.fwx?\&position=1$5 \&$ archive Type $=$ ImageFolder $\&$ archive $I d=5000 \&$ albumId $=5000 \& \mathrm{~s}$ orting=ModifiedTimeAsc \&search $=$ ocelote $\&$ fileId $=6$ FB6F18652D 1 5134466A77B2F5CCD42CE3B6252798CA3B655C4205E5C5A15C809915DE91215801A (Consulta: agosto de 2012).

RDA: resources description \& access (2011), Developed in a collaborative process led by the Joint Steeering Committee for Development of RDA (JSC) representing The American Library Association [et al.], Chicago, Ill.: American Library Association: Ottawa, Ont.: Canadian Library Association : London: Chartered Institute of Library and Information Professionals, 1 v. (varias paginaciones). 
Reglas de catalogación angloamericanas (2004), Preparadas bajo la dirección del Joint Steering Committee for Revisión of AACR, un comité de la American Library Association [et al.]; tr. y rev. general por Margarita Amaya de Heredia, $2^{a}$ ed., rev. de 2002, actualización de 2003, Bogotá, D. C.: Rojas Eberhard, 1 v. (varias paginaciones).

Weber, Mary Beth y Fay Angela Austin (2004), Describing electronic, digital, and other media using AACR2 and RDA: a how-to-do-it manual and CD-ROM for librarians, New York: Neal-Schuman Publisher, 2004, pp. 1-3. How-to-do-it manuals: Núm. 168. 


\title{
Del libro electrónico y las bibliotecas digitales. Estado de la cuestión en España
}

\author{
FRANCISCO JOSÉ VALENTÍN RUIZ \\ Y JUAN Miguel SÁNCHEZ VigIL \\ Universidad Complutense de Madrid, España
}

\section{INTRODUCCIÓN}

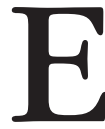

$s$ un hecho conocido que toda evolución técnica de un objeto o de un concepto siempre trata de emular la tecnología que pretende mejorar o sustituir. De igual modo, esta mejora de la tecnología existente no cala en la sociedad si no hay un convencimiento claro de los beneficios que produce.

Un ejemplo es el correo electrónico; en sus inicios, era una copia virtual del correo convencional. Incluso hoy mantenemos gran parte de las convenciones que, durante siglos, se han ido implantando en el correo postal: la terminología de "buzones de entrada y salida"; la simbología (sobres abiertos o cerrados para representar los mensajes leídos y sin leer); uso de membretes y de firmas con formatos determinados... Pero con el tiempo, y en ocasiones, estos nuevos avances acaban por separarse del medio del que proceden e introducen innovaciones y mejoras que van un paso más allá.

Con las bibliotecas ha ocurrido precisamente esto. Los catálogos en línea (OPAC) fueron, en sus orígenes, el fruto de trasladar los ficheros existentes en las bibliotecas, formados por cajoneras llenas de fichas de papel, a la pantalla del ordenador. Hoy tienen muy poco que ver con eso y la tecnología está haciendo que, 
desde los catálogos de las bibliotecas, se pueda acceder directamente a los contenidos en línea, a información adicional sobre el recurso, a contenidos relacionados con el mismo autor y con los mismos temas, o que exista la posibilidad de mostrar valoraciones de otros usuarios. Vemos pues que el fundamento se encuentra en los antiguos catálogos de fichas en papel, pero las tecnologías ofrecen unas posibilidades muy superiores a las de un mueble de madera. La emulación ya no es tan clara como en los orígenes y las necesidades de los usuarios van a hacer que en los próximos años las diferencias sean aún más notables.

En los últimos tiempos, se ha producido lo que ha venido en llamarse la "revolución digital": la tecnología ha conseguido que podamos acceder a infinidad de información desde dispositivos de todo tipo (ordenadores, tabletas, móviles, etcétera), y parece que la tendencia es a que todo tenga que encontrarse en formato digital. Como en los casos del correo postal y de los catálogos de las bibliotecas, en éste la tecnología a imitar es el libro. Sin embargo, podemos decir que son ejemplos comparables, con una salvedad: en los inicios de la revolución digital se consideraba que el libro era ya perfecto tal y como estaba configurado y que sus sustitutos tecnológicos no podrían estar a la altura, no lograrían alcanzar sus cualidades artísticas ni serían capaces de imitar la capacidad de los libros convencionales de estimular nuestros sentidos. Este grupo de defensores, cuyo representante más célebre es Umberto Eco (1998), tuvo gran popularidad en un momento en el que la calidad de las pantallas y las funcionalidades que eran capaces de ofrecer los dispositivos eran muy limitadas. Se trataba, sin duda, de la postura más razonable ante quienes pronosticaban la desaparición del libro impreso.

Sin embargo, la continuidad en este debate, abierto desde la década de los ochenta del siglo pasado, empieza a ser vista como una pérdida de tiempo que, por otra parte, no es sino el reflejo del avance tecnológico en el que mandan las empresas. Los vaticinios suelen estallar en las manos. Hace apenas unos meses se desarrollaba la gran batalla por poner en el mercado el mejor $e$ reader, y sin embargo el asunto de los "aparatos" de lectura toma 
otros derroteros, como era obvio que sucedería si pensamos en los intereses que están en juego.

Por tanto, nos encontramos con que el tiempo ha pasado, la tecnología ha evolucionado y se ha conseguido mejorar en gran medida la calidad de los dispositivos y sus pantallas. De modo que ahora existen modelos de pantallas que se basan en el mismo principio del papel y emplean la luz ambiente para mostrar el texto (tinta electrónica), a diferencia de las pantallas convencionales que son retroiluminadas. Así, las cualidades de visualización son comparables a las del papel y tampoco cansan la vista. Además, la tecnología también ha evolucionado en el sentido de crear nuevas concepciones literarias que tienen cabida en el mundo digital, pero que difícilmente podrían incorporarse al impreso. Se trata de los conceptos de literatura digital o ciberliteratura, términos con los que se hace referencia a expresiones artísticas nacidas en electrónico que sólo podrían pasar a formato impreso si se asume una pérdida de esencia derivada de la naturaleza de estos formatos (Gutiérrez; Marino; Gervás; Borrás, 2009).

Con todo esto, nos encontramos con que hay una serie de conceptos que entran en colisión dependiendo de si el formato es electrónico o impreso. Por ese motivo creemos necesario analizar brevemente el concepto libro para tratar de esclarecerlos.

Podríamos decir que un libro siempre ha sido un soporte, durante más de 1000 años referido a un grupo de hojas encuadernadas con unas tapas, anteriormente un rollo; y en épocas aún más remotas, un objeto compuesto por otros materiales capaz de transmitir textos. Pero, al mismo tiempo, un libro es el contenido: cuando nos referimos a la calidad de un determinado libro de un autor concreto, no estamos hablando en general de la cubierta o de la disposición de los textos; hablamos de la obra en sí, de obras literarias (este ejemplo trasladado a la producción científica o a otra tipología de obras es análogo). De modo que podemos entender que el libro impreso es el medio tradicional de los autores para dar a conocer su obra; es decir, es el medio que tiene la literatura (o la ciencia y la tecnología) de ser comunicada. Y el que el libro como soporte sea papel o sea un dispositivo 
electrónico (se ha dado en llamar a algunos de estos dispositivos libro electrónico) es indiferente, pues se trata simplemente de medios de difusión.

La definición que la legislación española ofrece para el concepto de libro camina en este sentido. Así, la disposición que nos ofrece una definición más reciente es la Ley 23/2011, del depósito legal, aunque se trata de una copia casi literal de la definición de libro de la Ley 10/2007, del 22 de junio, de la lectura, del libro y de las bibliotecas (Tabla 1):

Tabla 1

\begin{tabular}{|c|c|}
\hline \multicolumn{2}{|c|}{ Definición de libro en diferentes disposiciones normativas españolas } \\
\hline $\begin{array}{l}\text { Ley 10/2007, de } 22 \text { de junio, de la lectura, } \\
\text { del libro y de las bibliotecas. } \\
\text { (Artículo 2, apartado a) }\end{array}$ & $\begin{array}{l}\text { Ley 23/2011, de } 29 \text { de julio, de depósito legal. } \\
\text { (Artículo 3) }\end{array}$ \\
\hline $\begin{array}{l}\text { Libro: obra científica, artística, literaria o de cual- } \\
\text { quier otra índole que constituye una publicación } \\
\text { unitaria en uno o varios volúmenes y que puede } \\
\text { aparecer impresa o en cualquier otro soporte sus- } \\
\text { ceptible de lectura. } \\
\text { Se entienden incluidos en la definición de libro, a } \\
\text { los efectos de esta Ley, los libros electrónicos y los } \\
\text { libros que se publiquen o se difundan por Internet } \\
\text { o en otro soporte que pueda aparecer en el futuro, } \\
\text { los materiales complementarios de carácter impre- } \\
\text { so, visual, audiovisual o sonoro que sean editados } \\
\text { conjuntamente con el libro y que participen del ca- } \\
\text { rácter unitario del mismo, así como cualquier otra } \\
\text { manifestación editorial. }\end{array}$ & $\begin{array}{l}\text { Libro: Obra científica, artística, literaria o de cual- } \\
\text { quier otra índole que constituye una publicación } \\
\text { unitaria en uno o varios volúmenes y que puede } \\
\text { aparecer impresa o en cualquier soporte suscepti- } \\
\text { ble de lectura. } \\
\text { Se entienden incluidos en la definición de libro, a } \\
\text { los efectos de esta Ley, los libros electrónicos y los } \\
\text { libros que se publiquen o se difundan por Internet } \\
\text { o en otro soporte que pueda aparecer en el futuro, } \\
\text { los materiales complementarios de carácter impre- } \\
\text { so, visual, audiovisual o sonoro que sean editados } \\
\text { conjuntamente con el libro y que participen del ca- } \\
\text { rácter unitario del mismo, así como cualquier otra } \\
\text { manifestación editorial. }\end{array}$ \\
\hline
\end{tabular}

La diferencia es sutil, y a nuestro entender, simplemente trata de equiparar aún más el libro impreso como soporte que usa otros medios de difusión como el electrónico. Pero de cualquier modo queda clara la referencia al libro como contenido (creación) cualquiera que sea su presentación, de forma que incluso puede interpretarse o imaginarse "en otro soporte que pueda aparecer en el futuro". Y queda claro también que en la definición se incluyen los libros electrónicos.

Libro electrónico, por tanto, se refiere a contenido y a continente (al igual que el impreso). Pero el concepto debe ser am- 
pliado pues el talento de los nuevos autores para crear obras empleando los más novedosos recursos tecnológicos, y la capacidad de los soportes digitales para mostrar estas expresiones, han ampliado el concepto de libro. Así, por toda la Red existen poemas con los que los lectores pueden interactuar, novelas en las que se entremezclan vídeos y sonidos, etcétera. Creemos entonces que el concepto de libro debe ser ampliado porque, al igual que las obras convencionales, tiene un carácter unitario (éste es uno de los criterios tradicionales para determinar si una creación podía tener la denominación de libro o no, y también está recogido en la definición de libro que ofrece la legislación), y estas nuevas expresiones artísticas (lo que hemos denominado literatura digital) también pueden tener esta consideración de todo y, por ende, ser consideradas como libro.

De cualquier modo, el reto no se encuentra en la definición de lo que es un libro y lo que no debe considerarse como tal. El desafío se encuentra en el establecimiento de un equilibrio entre el mercado digital y el del papel, pues el libro impreso es el motor de la industria editorial española y, todavía, el soporte por excelencia, al menos en el mundo literario ("Situación actual y perspectivas...”, 2012).

\section{CONTEXTUALIZACIÓN: HACIA EL LIBRO ELECTRÓNICO}

Los libros electrónicos (hablando de dispositivos) no siempre han sido como los conocemos, y podríamos afirmar que han tenido una evolución accidentada, por decirlo de algún modo. Hemos pasado de pantallas de cristal líquido de tan solo dos colores y de pequeño tamaño, con una visibilidad muy reducida y en las que la experiencia de lectura era muy deficiente, a la aparición de la tinta electrónica y hasta la explosión de los dispositivos denominados tablet o tabletas, sin olvidarnos de la gran popularidad de la telefonía móvil. Veamos con más detenimiento la evolución tecnológica de algunos de estos avances. 


\section{Libros electrónicos y tinta electrónica}

La evolución de los dispositivos portátiles ha sido espectacular durante los últimos 20 años. Pero, a lo largo de todo el siglo Xx, han surgido visionarios que han realizado predicciones, más o menos acertadas o incluso que podrían definirse como de ciencia ficción, acerca del futuro de tales dispositivos. La primera de ellas podemos situarla en 1911, cuando Edison predijo (Vázquez; Celaya, 2012) "que en el año 2011 existirán pequeños soportes de lectura de libros hechos de hojas de níquel en los que los lectores podrán almacenar toda una biblioteca en un solo volumen".

Por su parte, Vannevar Bush (1945) nos explicaba que a través de métodos fotográficos adecuados podría fabricarse un dispositivo que permitiera almacenar una cantidad muy elevada de libros en un aparato del tamaño de un escritorio de oficina. Este aparato, denominado memex, estaba diseñado como un puesto de lectura individual con características semejantes a las de algunos ordenadores personales actuales. El diseño de prototipos de este tipo se disparó durante los años posteriores de forma espectacular, pero mediante diseños que se acercaban cada vez más a la apariencia que tienen los artefactos tecnológicos actuales, destacando el Dynabook en 1968 (Kay; Goldberg, 1977) un "medio personal y dinámico del tamaño de un cuaderno que cualquiera podría poseer y que podría permitir manejar información relacionada con las necesidades de sus dueños."

No será hasta 1993 cuando se materialice el primero de los dispositivos portátiles: el Newton MessagePad, diseñado por uno de los visionarios de Dynabook, Alan Kay (Valentín Ruiz, 2011), que puede considerarse como la primera PDA (Personal Digital Assistant: Asistente Personal Digital) de la historia. Este artilugio permitía la lectura de libros electrónicos con las limitaciones impuestas por la pantalla que incorporaba el dispositivo: de dos colores y con una pésima resolución.

Igual suerte que esta primera PDA corrieron los primeros dispositivos dedicados a la lectura de libros electrónicos que surgieron en 1998, los célebres Rocket eBook y Softbook con un 
más que limitado volumen de ventas, en torno a 50000 unidades (Monteoliva; Pérez Ortiz; Repiso, 2008). Este éxito reducido se debe a razones similares a las de las primeras PDA: pantallas con mala experiencia de lectura (retroiluminadas), de pequeño tamaño, con una duración muy limitada de sus baterías y, al mismo tiempo, ausencia de contenidos digitales en la Red que pudieran consumirse a través de estos aparatos.

Por este motivo, el primer hito en la reciente historia de los dispositivos digitales es el que ha supuesto un auténtico cambio de tendencia, y debemos establecerlo en la comercialización de la tinta electrónica y, más concretamente, a partir de 2007, aunque el primer ejemplo de un dispositivo de tinta electrónica lo encontremos en 1999 (e Ink Corporation's, 1999). A partir de entonces han proliferado decenas de dispositivos comercializados por distintas empresas, como Astak, Barnes\&Noble, Booken, Fujitsu, Hanlin, Iliad o Kindle (Amazon) y en España, Inves, BQ o Papyre (Grammata) (Valentín Ruiz, 2011).

La evolución lógica de este tipo de dispositivos parecía ser el salto de las pantallas de tinta electrónica a las pantallas de color, ya que hasta ahora éstas estaban pensadas para soportar blanco y negro para textos y escala de grises para las imágenes. Sin embargo, es evidente que el mercado de las tabletas está tomando fuerza y lo elevado de los precios de la tinta electrónica a color y la fuerte competencia impuesta por las tabletas (Cordón García, 2011) podría estar limitando el futuro de la tinta electrónica.

Todo esto, incluidas las ventajas de los dispositivos de tinta electrónica, está diseñado para proporcionar una experiencia de lectura similar a la del papel, pues sus pantallas no producen reflejos y no están retroiluminadas; la duración de las baterías es enorme pues estos aparatos sólo consumen energía en las operaciones de paso de página; permiten almacenar miles de libros; y su pequeño tamaño y reducido peso los hace aptos para desplazarlos a cualquier lugar con las máximas garantías de comodidad.

No obstante, pese a las cifras y predicciones que auguran un descenso del uso de dispositivos de tinta electrónica, en España el mercado de estos aparatos se encuentra en su momento más 
dulce, quizá motivado por el desembarcó en 2011 del Amazon Kindle, con un precio de 99 euros, porque el mercado no está tan avanzado como en otros países de nuestro entorno, y por los precios competitivos de los dispositivos comercializados en España, principalmente los de la empresa BQ. Así, el volumen de ventas de los e-readers se estableció en 2011 en torno a las 285000 unidades, un 500\% más que el año anterior (La sociedad de la información..., 2013). Existen más datos que apoyan la afirmación de que los dispositivos de tinta electrónica son los favoritos actualmente por la población española lectora en digital. De hecho, el mayor porcentaje de quienes afirman leer en digital indica hacerlo utilizando un dispositivo de tinta electrónica según una encuesta elaborada por la revista Delibros (Tabla 2):

Tabla 2

\begin{tabular}{|l|c|c|c|}
\hline \multicolumn{4}{|c|}{ Uso de dispositivos de lectura por la población lectora } \\
en formato digital.
\end{tabular}

Fuente: Delibros, enero 2013

\section{Tabletas}

Hemos hablado de las ventajas de los dispositivos de tinta electrónica, pero las tabletas también tienen las suyas: incluyen pantallas de enorme resolución a todo color, permiten navegar por Internet, disponen de una enorme variedad de aplicaciones adicionales a la lectura de libros, y también constituyen una tecnología portátil y con una aceptable duración de baterías (teniendo en cuenta todas las funcionalidades que poseen). Sin embargo, cuando los libros electrónicos de tinta electrónica no habían llegado a las cifras de venta que se esperaban para ellos, empe- 
zaron a decaer en favor de las tabletas, que surgieron en 2010, cuando Apple lanzo su iPad.

De hecho, en un artículo publicado en el Boletín del Observatorio de la Lectura y el Libro ("Cae la demanda...", 2013) basado en varios estudios internacionales, se establece que a nivel mundial las ventas de dispositivos de tinta electrónica han caído en 2012 entre un $37 \%$ y un $57 \%$ con respecto a 2011 , frente a la venta de tabletas de diversos fabricantes que han seguido los pasos de Apple, y han experimentado un crecimiento del 64\% en 2012 (Figura 1).

Figura 1

Pronóstico de ventas de dispositivos de tinta electrónica en todo el mundo

(en millones de unidades).

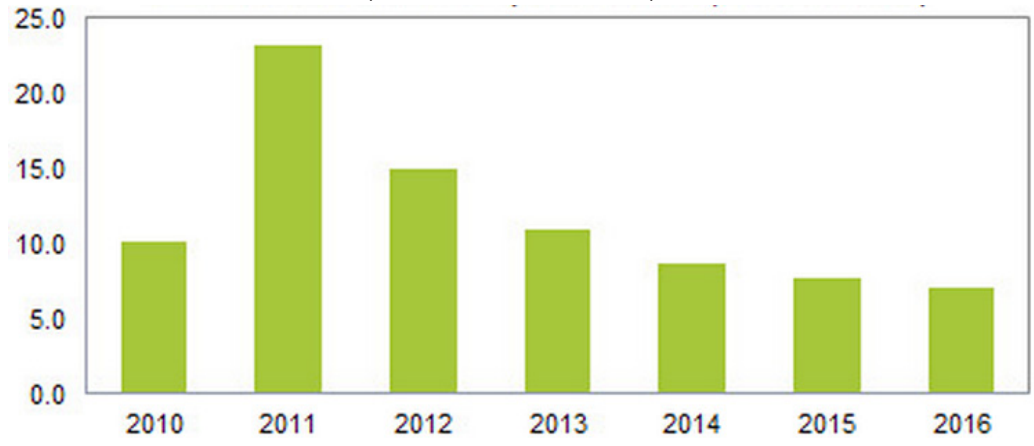

Fuente: Selburn, 2013.

En España, esta tendencia de descenso en la adquisición de dispositivos de tinta electrónica todavía no se ha manifestado. De hecho se constata que, aunque los soportes más habituales para la lectura son los ordenadores, en un estudio de la Federación de Gremios de Editores de España se puede apreciar (Figura 2) que desde 2010 se había producido un aumento en el uso de todos los dispositivos electrónicos de lectura, pero especialmente en los dispositivos de tinta electrónica (Hábitos de lectura..., 2013). 
Biblioteca Digital Académica en Bibliotecología...

Figura 2

Dispositivos utilizados por los lectores en soportes digitales en España.

$-2010 \quad-2011 \quad \square 2012$

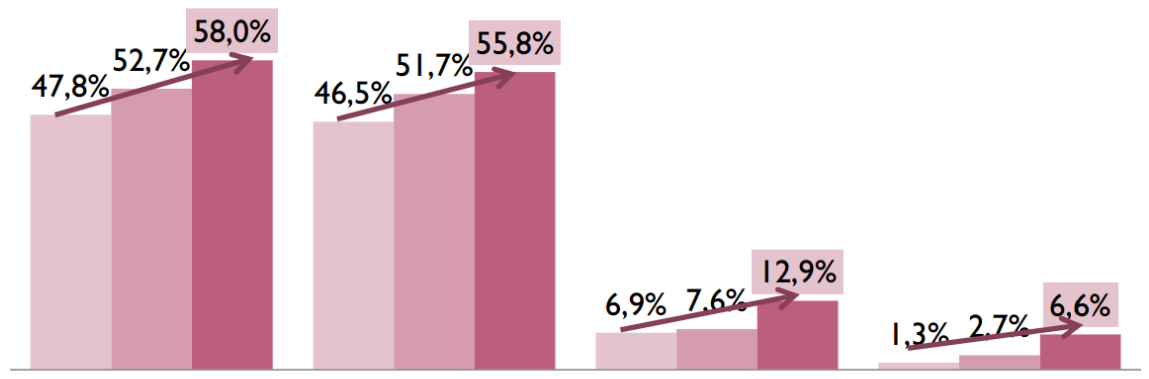

Total lee en soporte Lee en el Ordenador Lee en el móvil, Lee en un E-Reader digital agenda electrónica...

Fuente: Hábitos de lectura..., 2013.

También cabe destacar de la Figura 2 un aumento de la población lectora en formatos digitales de más de diez puntos porcentuales en sólo dos años. Y por último, resalta el dato del enorme incremento de la población que utiliza su teléfono móvil para la lectura, circunstancia que nos permite enlazar con el siguiente apartado.

\section{Móviles}

La generalización del uso de la telefonía móvil y la evolución de los terminales hasta la llegada de los dispositivos denominados smartphones está haciendo que la tendencia del mercado se dirija hacia esta nueva generación de artefactos. De hecho los móviles han evolucionado incorporando pantallas de mayor tamaño y buenas condiciones de visualización y han aumentado sus prestaciones, de modo que en algunos sentidos son comparables a las de las tabletas. Podría parecer que a pesar de sus dimensiones reducidas no serían seleccionados por los usuarios como soportes de lectura; sin embargo, los estudios estadísticos que se han 
realizado al respecto parecen indicar lo contrario. Así, podemos mostrar un claro incremento del consumo de libro electrónico a través de dispositivos móviles con un aumento del 25\% en 2010 (Wattpad Global Ebook), a nivel mundial. Además, se prevé que el aumento en España de la tecnología móvil para el consumo de contenidos digitales (incluidos los libros) sea especialmente importante, pues aproximadamente el $10 \%$ de la población poseía en 2012 un Smartphone, lo que convirtió a España en líder europeo en este sentido ("España, líder europeo...", 2012).

Todas las cifras indican, pues, que la utilización de tabletas y telefonía móvil para el consumo de libros electrónicos y otro tipo de contenidos irá en crecimiento durante los próximos años, puesto que "los españoles son los europeos que más dispositivos tecnológicos poseen, superando la media europea para todos los tipos de terminales e incluso doblándola en el caso de las tabletas (un 14\% frente al 7\% de la media europea)" (La sociedad de la información..., 2013).

En resumen, podemos afirmar que, cuando comenzaron a surgir dispositivos dedicados a la lectura de libros electrónicos, el debate se centraba en la calidad de la visualización de las pantallas y en la experiencia de lectura y que hoy, tan sólo unos años después, ya no se cuestiona este aspecto. Y no porque no estemos en la misma situación (las pantallas de las tabletas producen reflejos y están retroiluminadas, las de los smartphones son además de reducido tamaño), sino porque los lectores en formato digital parecen estar decantándose por dispositivos con mayores funcionalidades que la simple posibilidad de lectura de libros electrónicos, anteponiendo funcionalidades a comodidad y calidad de lectura. Ante tal circunstancia sólo nos queda esperar para ver qué nos deparará el futuro y cuáles serán los artilugios tecnológicos (actuales o aún por inventar) que se acabarán imponiendo. Quizá sólo se trate de esperar un equilibrio entre los diferentes dispositivos existentes. 


\section{EVOLUCIÓN DE LAS BIBLIOTECAS}

Paralelamente a la evolución de las bibliotecas se han venido acuñando diferentes conceptos para hacer referencia a las nuevas posibilidades que estos centros culturales ofrecían a los usuarios. Así, los términos biblioteca electrónica, biblioteca virtual y biblioteca digital comenzaron a referirse a la funcionalidad y el acceso a diferentes servicios a través de la Red, y a la larga acabaron por ser un equivalente de acceso al texto completo de los documentos que albergan, siendo éste su principal reto. Así, los conceptos de biblioteca electrónica, virtual y digital podrían considerarse hoy casi sinónimos, aunque por supuesto existen autores que han realizado análisis profundos sobre el alcance de cada uno de ellos (Saorín, 2002) y han establecido diferencias más o menos marcadas. Nosotros, sin querer entrar en debates de este tipo, emplearemos en este trabajo el término biblioteca digital por ser el más utilizado actualmente.

\section{Tecnología bibliotecaria: hacia la biblioteca digital}

Puede decirse que el impacto de la evolución tecnológica en las bibliotecas ha llevado al cambio terminológico. La mecanización en las tareas de la biblioteca y el acceso público en línea desde los OPAC llevó al uso del término electrónico (Amat, 1990), que evolucionó hacia digital a partir de la década de los noventa. El Diccionario Enciclopédico de las Ciencias de la Documentación (López Yepes, 2004) define biblioteca digital como el "Sistema de información que mantiene y proporciona acceso remoto a una o varias colecciones de publicaciones digitales". En cuanto al origen del concepto, las referencias son las aportaciones de Vannevar Bush y Teodor Nelson acerca del hipertexto.

Podemos considerar a través de estas definiciones que la biblioteca digital es un estado más avanzado en la automatización de la biblioteca (Saorín, 2002). Y para entender la evolución que ha llevado a las bibliotecas a buscar la consideración de digital, 
hemos de comprender el proceso de automatización que ha tenido lugar, principalmente desde la segunda mitad del siglo XX. Varios autores definen la automatización como el procesamiento automático y semiautomático de datos para llevar a cabo las actividades tradicionales de la biblioteca (Salmon, 1975. García Camarero; García Melero, 2001). Es un proceso que no podría haber tenido lugar si no hubiera sido en un contexto de enorme convergencia internacional en cuanto a los procesos bibliotecarios.

Podemos entonces encontrar hitos que han supuesto cambios radicales en la forma de concebir las bibliotecas y el intercambio de información, como la creación del formato MARC, pero que han tenido en el auge de la información digital y en el surgimiento de Internet su principal aliciente (Saorín, 2002). Pues bien, tras años de evolución de diferentes actividades como la circulación o el proceso técnico, mediante diferentes desarrollos tecnológicos basados en grandes computadores, aparecieron los microordenadores durante la década de 1980 (Rayward, 2002) y comenzó lo que podemos considerar una auténtica revolución en la automatización de bibliotecas.

Estos ordenadores de más reducido tamaño, cada vez con mayor capacidad de computación y a precios asequibles, motivaron la aparición de desarrolladores comerciales de programas informáticos dedicados a la gestión de bibliotecas. Y con los desarrollos informáticos surgieron los sistemas integrados de gestión de bibliotecas (SIGB), aplicaciones informáticas que permiten administrar de forma integral e interrelacionada todos los procesos bibliotecarios. Los SIGB comerciales han acaparado la práctica totalidad de las automatizaciones de medianas y grandes bibliotecas desde los años noventa.

Sin embargo, el enorme avance tecnológico en el que nos encontramos sumergidos ha hecho que constantemente se exijan nuevas funcionalidades a los SIGB, como la completa integración con los contenidos digitales y las aplicaciones de la Web 2.0, la incorporación de herramientas de descubrimiento y la integración automática con catálogos de ámbito internacional. En España la situación de crisis económica que ha mermado enormemente los 
presupuestos de las bibliotecas y centros culturales públicos hace que sea especialmente complicado para muchas instituciones dar un paso más en la incorporación de funcionalidades, pues suponen costosas inversiones ya que los SIGB convencionales no están diseñados para abordar algunas de estas nuevas necesidades.

Es por todas estas razones que desde 2011 ha surgido un nuevo producto bautizado como "plataformas de servicios bibliotecarios" (Breeding, 2012) basadas en la tecnología cloud computing "que proporcionan un enfoque más amplio para la gestión de contenidos que los SIGB" (Valentín Ruiz; Fernández Sánchez; Torre-Marín, 2012). Algunas organizaciones que ya han comercializado sus servicios bibliotecarios son OCLC (WorldShare Management Services), Ex Libris (Alma) o Intota (Serials Solutions).

Las ventajas de estas plataformas de servicios en la nube frente a los SIGB se encuentran en las posibilidades de incorporación automática de herramientas de descubrimiento y de aplicaciones de la Web 2.0, entre otras nuevas funcionalidades; la posibilidad de agrupar costos y reducirlos; la incorporación de contenidos digitales a texto completo de una forma ágil; o la incorporación automática de actualizaciones y mejoras ya que las aplicaciones no se encuentran alojadas en las instalaciones de la biblioteca sino en servidores externos de los proveedores de servicios.

Pero, ¿qué tiene que ver esta nueva generación de software bibliotecario con las bibliotecas digitales? Pues que para crear bibliotecas digitales son imprescindibles plataformas que permitan realizar búsquedas potentes sobre los contenidos y, al mismo tiempo, mostrarlos de una forma adecuada a texto completo, algo que estaba limitado en los tradicionales OPAC de las bibliotecas y para lo que los SIGB no estaban preparados.

\section{Las bibliotecas digitales}

Podemos considerar que la primera iniciativa de creación de una biblioteca con textos digitales fue el Proyecto Gutenberg (Project Gutenberg, 2011). Proyecto cuyo primer texto digitalizado fue la Declaración de Independencia de los Estados Unidos, introduci- 
da en un ordenador de forma manual por Michael Hart, el fundador del proyecto, en 1971 (Hart, 1992). La visibilidad de este primer texto fue muy reducida, sobre todo teniendo en cuenta que las redes existentes en la época poco tenían que ver con la World Wide Web, la cual aparecería varios años después.

De modo que el verdadero impulsor del proyecto fue el desarrollo de Internet y la aparición de los primeros navegadores. Todo ello hizo crecer el número de documentos de la colección (diez en 1989) hasta el número de 32 nuevos textos mensuales en 1996 (Lebert, 2009), fruto de la colaboración de los participantes en el proyecto. Es decir que hasta que no se socializó la creación de documentos electrónicos a través de una pléyade de aplicaciones que permitían generar textos electrónicos, digitalizar documentos, utilizar funcionalidades de reconocimiento óptico de caracteres, etcétera, no se produjo la explosión del proyecto.

Sea como fuere, podemos considerar el caso del Proyecto Gutenberg como anecdótico $\mathrm{y}$, pese a su temprano nacimiento, su verdadero crecimiento ha tenido lugar en fechas bastante más recientes. De modo que el incremento sustancial de documentos aportados al proyecto a partir de los años noventa coincide con la época en la que las bibliotecas han empezado a ofrecer colecciones digitales de documentos. Estas primeras colecciones son el fruto de diferentes iniciativas de puesta a disposición de textos científicos en bases de datos comerciales y que han sido la apuesta digital de distintos grupos editoriales como Safari, Springer y Elsevier. Primero fueron recopilaciones de bases de datos de textos científicos y más tarde colecciones de libros electrónicos que se adquirían a través de distintos modelos de suscripción.

Las bibliotecas, especialmente las universitarias, han ido contratando licencias de acceso a bases de datos y a colecciones de libros electrónicos, y creando repositorios institucionales de forma continuada, pero con el enorme inconveniente de que no era posible contar con una única terminal de consulta para la ingente cantidad de recursos con que empezaban a contar. Los usuarios se convertían así en los principales perjudicados porque se encontraban desbordados ante la enorme cantidad de recursos 
bibliotecarios disponibles para solventar unas necesidades de información que podían ser muy concretas.

De este modo las bibliotecas se vieron obligadas a partir del año 2000 a buscar soluciones ante esta situación de proliferación de fuentes de información digitales y falta de herramientas que les proporcionaran un acceso unificado a ellas. Y la solución de la época fueron los metabuscadores.

Sin embargo, ¿podemos considerar esta integración primitiva de los recursos digitales de las bibliotecas universitarias a través de metabuscadores como un primer ejemplo de biblioteca digital? A nuestro entender no, porque las deficiencias de estas aplicaciones eran mayores que sus ventajas al tener unos sistemas de ordenación de resultados bastante deficientes y contar con procesos de búsqueda bastante lentos y poco intuitivos. Hasta tal punto es así que la tendencia actual es hacia su desaparición progresiva en favor de una nueva generación de herramientas de integración: los discoveries (o plataformas de descubrimiento). Estas herramientas permiten integrar los recursos de la biblioteca y el catálogo general a través de una interface mucho más intuitiva que permite partir de una caja de búsqueda simple y realizar filtros sucesivos en función de los intereses de los usuarios. Las herramientas más comunes de este tipo son WorldCat Local (OCLC), Summon (Serials Solutions), Ebsco Discovery Service (Ebsco) y Primo (Ex Libris) (Vaughan, 2011).

Por tanto las bibliotecas universitarias avanzan con firmeza hacia la creación de la biblioteca digital. Ya han sido capaces de integrar los recursos digitales (bases de datos, colecciones de libros electrónicos y repositorios institucionales) y los SIGB a través de herramientas de descubrimiento. El reto es que los procesos de selección individualizada de obras se incorporen también al formato digital, pues por ahora sólo se hace con paquetes comerciales de libros electrónicos. Es decir, por ahora, la mayoría de las bibliotecas no están adquiriendo libros electrónicos a libreros como lo hacían con los impresos, sino que adquieren paquetes de libros electrónicos de los editores. Esto supone que los centros están pagando por libros que realmente no necesitan. Para 
superar este reto (entre otros) ha surgido esta generación de plataformas de servicios bibliotecarios a las que nos referíamos anteriormente y que caminan hacia una integración total del mundo impreso y el digital.

Hemos hablado de las bibliotecas universitarias por ser las que han logrado que hacer un mayor esfuerzo y las que han tenido una mayor vinculación histórica con los contenidos digitales antes de la llegada del libro electrónico. Pero ¿qué ha pasado con las bibliotecas públicas? Pues la llegada del libro electrónico supuso todo un reto y la opción mayoritaria hasta ahora para pasar a digital ha consistido en la adquisición de dispositivos de lectura con los libros electrónicos cargados (esto también lo han hecho las bibliotecas universitarias).

Queremos decir con todo esto que no existen hasta hoy bibliotecas digitales. Pues en el sentido de que la biblioteca sea completamente digital con todos sus contenidos en este formato los ejemplos son muy escasos. Existen, eso sí, fondos digitales de características especiales que se han puesto a disposición de los usuarios a través de interfaces denominadas bibliotecas digitales. En el apartado "Ejemplos de bibliotecas digitales: compartir conocimiento" mostraremos con detalle algunos ejemplos. Ahora analizaremos con más detenimiento otros aspectos que también son importantes para la comprensión actual de las bibliotecas digitales.

Hemos indicado que actualmente las bibliotecas adquieren paquetes de libros electrónicos cuyo modelo de acceso es el de suscripción; por ejemplo, anualmente, la biblioteca paga una tarifa y los lectores tienen acceso a los contenidos desde los ordenadores de la biblioteca o a través de usuarios y contraseñas registrados. Sin embargo estos paquetes de libros electrónicos no están pensados para la descarga y, en caso de que así sea, generalmente se ofrecen en pdf, de modo que la visualización en los dispositivos de tinta electrónica es muy deficiente. Aunque debemos reconocer que cada vez se ofrece más la posibilidad de descarga en otros formatos como ePub. 
Por otra parte hemos indicado que las bibliotecas se encuentran ante el reto de incorporar la compra habitual de libros (directamente a librerías) también al formato digital. Es decir, que la biblioteca pueda adquirir un libro en formato electrónico y pueda gestionarlo como lo hace con los libros impresos sin tener que suscribir una colección completa. Pero, ¿por qué supone esto una dificultad añadida? Pues porque los DRM (Digital Right managment: Gestión de Derechos Digitales) imponen restricciones al préstamo de libros electrónicos: sólo es posible utilizar el libro en un determinado número de dispositivos de forma simultánea, por ejemplo. Restricciones que son difíciles de gestionar con los tradicionales SIGB porque éstos están pensados para prestar objetos físicos por un determinado tiempo y es el usuario el que devuelve el libro, renueva su préstamo, etcétera.

La única forma de solventar esta situación es mediante la determinación que han tomado muchas bibliotecas: los centros adquieren dispositivos de tinta electrónica, tabletas, tarjetas de memoria, etcétera, en los que cargan los contenidos, y ellos prestan de forma similar a los libros impresos. Pero esto no es una práctica viable ni ágil (Cordón García, Gómez Díaz, Alonso Arévalo, 2011). Por este motivo, se han desarrollado plataformas que permiten gestionar los libros respetando los DRM. Un ejemplo es OdiloTK, que se está implantado de forma satisfactoria en las bibliotecas públicas de Cartagena (Tornel Cobacho; Sánchez Martínez, 2012).

Esto es en cuanto a España; en el caso de Estados Unidos (donde se ha llevado la iniciativa en todo lo relacionado con el libro electrónico), el préstamo de libro electrónico es un aspecto superado. De hecho, en un estudio del distribuidor de libros electrónicos OverDrive, se ponía de manifiesto que el préstamo de libros electrónicos en las bibliotecas norteamericanas creció $200 \%$ en 2010. Los datos ofrecidos por este estudio también indicaban que los préstamos digitales habían llegado durante los tres primeros cuartos de 2011 a los 12 millones, y que más de dos tercios de las librerías en Estados Unidos ofrecían préstamos de libros electrónicos ("El préstamo de libros...", 2011). 


\section{LIBRO ELECTRÓNICO, BIBLIOTECAS Y SECTOR EDITORIAL}

El sector editorial ha tenido mucho que ver con la llegada del libro electrónico, aunque actualmente se le esté acusando en España de la ralentización de la definitiva implantación de lo digital. En este sentido, algunos expertos y tecnólogos desconocedores del sector en profundidad indican que esto se debe al retraso tecnológico de los editores (Gil; Rodríguez, 2011). Cuando, de hecho, la edición electrónica es anterior a la existencia del propio libro electrónico: "la edición electrónica o digital existe desde que se aplicaron los ordenadores al proceso productivo" (Sánchez Vigil, 2009) y todos los procesos relacionados con la producción del libro son digitales actualmente.

\section{Aspectos a tener en cuenta}

De cualquier modo, sí es cierto que falta una apuesta del sector editorial por lo digital. Esto, a nuestro entender, se debe a cuatro circunstancias fundamentalmente:

- La ausencia de una hoja de ruta que planee la transición digital, aspecto éste del que son responsables editores, asociaciones de editores y administraciones públicas en su papel de fomento de la cultura (Gil; Rodríguez, 2011).

- El temor del sector editorial ante amenazas como las de la piratería, que ha puesto en un brete a otrora potentes industrias, como la discográfica.

- La tercera causa estaría relacionada con la escasez de demanda de contenidos digitales.

- La crisis económica sería el cuarto motivo. Muchas editoriales han visto mermados sus recursos y se han visto en la obligación de reducir sus plantillas y de mantener su actividad tradicional sin posibilidades de invertir esfuerzos en el salto al mundo digital. 
En cuanto a los temores de la industria editorial relacionados con la piratería, hemos de decir que tienen fundamento. España posee uno de los índices de piratería más altos del mundo. Según el Barómetro de Hábitos de Lectura y Compra de Libros de 2012 (Federación de Gremios de Editores de España, 2012), de los usuarios de contenidos electrónicos, sólo el 32\% paga por ellos; el resto los consigue por otros medios, legales o no. Por otra parte, en un informe elaborado por el Congreso de los Estados Unidos en 2011 (United States Congress, 2011), se situaba a España como uno de los cinco países del mundo con mayores problemas para asegurar el cumplimiento de la normativa de propiedad intelectual. Por tanto, el temor a que un contenido en formato digital sea automáticamente pirateado es compartido por muchos editores, aunque no va a evitar que finalmente las obras estén disponibles en estos formatos (Cordón García; Gómez Díaz; Alonso Arévalo, 2011).

Por otra parte, actualmente la demanda de contenidos en formato digital en España es baja. Sirvan los datos de los Barómetros elaborados por la Federación de Gremios de Editores de España: el número de lectores de libros en formato digital se ha incrementado desde 2010 hasta alcanzar el 11,7\%; y de este porcentaje sólo el 32\% adquiere libros en formatos electrónicos (Federación de Gremios de Editores de España, 2011; 2012). El consumo de contenidos en formato digital también puede extraerse de los datos de facturación de la industria española del libro que se muestran en la Tabla 3. 
Del libro electrónico y las bibliotecas digitales...

Tabla 3

\begin{tabular}{|c|c|c|c|c|c|c|c|c|c|}
\hline \multicolumn{10}{|c|}{$\begin{array}{l}\text { Datos de facturación del sector editorial en España. Comparación de la facturación procedente de la } \\
\text { edición digital } \\
\qquad \text { en comparación con la facturación total del sector. }\end{array}$} \\
\hline & \multicolumn{3}{|c|}{2009} & \multicolumn{3}{|c|}{2010} & \multicolumn{3}{|c|}{2011} \\
\hline & A & B & C & $A$ & B & C & $A$ & B & C \\
\hline $\begin{array}{c}\text { FACTURACIÓN } \\
\text { TOTAL }\end{array}$ & 51259,00 & 3109,58 & $1,65 \%$ & 70494,00 & 2890,80 & $2,44 \%$ & 72576,00 & 2772,34 & $2,62 \%$ \\
\hline Literatura & 3378,00 & 713,27 & $0,47 \%$ & 2641,00 & 643,69 & $0,41 \%$ & 12520,00 & 550,83 & $2,27 \%$ \\
\hline Novela & 3010,00 & 631,19 & $0,48 \%$ & 2486,00 & 588,64 & $0,42 \%$ & 12251,00 & 507,13 & $2,42 \%$ \\
\hline Poesía, teatro & 67,00 & 18,66 & $0,36 \%$ & 121,00 & 8,58 & $1,41 \%$ & 125,00 & 7,62 & $1,64 \%$ \\
\hline Otros literatura & 301,00 & 63,42 & $0,47 \%$ & 34,00 & 46,47 & $0,07 \%$ & 145,00 & 36,08 & $0,40 \%$ \\
\hline $\begin{array}{l}\text { Literatura infantil } \\
\text { y juvenil }\end{array}$ & 389,00 & 350,47 & $0,11 \%$ & 379,00 & 350,50 & $0,11 \%$ & 1082,00 & 337,61 & $0,32 \%$ \\
\hline $\begin{array}{l}\text { Texto no } \\
\text { universitario }\end{array}$ & 347,00 & 844,45 & $0,04 \%$ & 7613,00 & 817,57 & $0,93 \%$ & 9321,00 & 868,01 & $1,07 \%$ \\
\hline $\begin{array}{l}\text { Científico técnico } \\
\text { y universitario }\end{array}$ & 15270,00 & 154,97 & $9,85 \%$ & 5290,00 & 153,77 & $3,44 \%$ & 3486,00 & 133,67 & $2,61 \%$ \\
\hline $\begin{array}{l}\text { Ciencias Sociales } \\
\text { y humanas }\end{array}$ & 14585,00 & 170,24 & $8,57 \%$ & 1761,00 & 156,03 & $1,13 \%$ & 2701,00 & 135,70 & $1,99 \%$ \\
\hline $\begin{array}{l}\text { Derecho } \\
\text { y ciencias } \\
\text { económicas }\end{array}$ & 5842,00 & 137,05 & $4,26 \%$ & 48589,00 & 143,28 & $33,91 \%$ & 38406,00 & 148,69 & $25,83 \%$ \\
\hline Religión & 130,00 & 33,52 & $0,39 \%$ & 307,00 & 34,38 & $0,89 \%$ & 401,00 & 32,05 & $1,25 \%$ \\
\hline Libros prácticos & 2428,00 & 161,84 & $1,50 \%$ & 150,00 & 126,28 & $0,12 \%$ & 981,00 & 148,83 & $0,66 \%$ \\
\hline $\begin{array}{l}\text { Divulgación } \\
\text { general }\end{array}$ & 624,00 & 274,19 & $0,23 \%$ & 1826,00 & 241,25 & $0,76 \%$ & 3141,00 & 212,31 & $1,48 \%$ \\
\hline Otros & 8264,00 & 74,82 & $11,05 \%$ & 1938,00 & 51,83 & $3,74 \%$ & 538,00 & 45,69 & $1,18 \%$ \\
\hline
\end{tabular}

A. Digital (Miles de euros)

B. Total facturación (millones de euros)

C. \% de facturación de digital sobre el total

Fuente: Federación de Gremios de Editores de España, 2011b 
En general se aprecia un progresivo aumento de la facturación relacionada con la comercialización de obras en formato digital especialmente acusado entre 2010 y 2011. Un aumento que además se mantiene en un momento en el que los volúmenes totales de facturación del sector se encuentran en clara recesión. Sin embargo, las cifras de 2011 son del 2,62\% de la facturación total, una cantidad poco apreciable en consideración al esfuerzo que el sector está haciendo por digitalizar los fondos de catálogo y por lanzar contenidos en formato digital (Tabla 4). Aunque también hay que tener en cuenta que muchos de estos contenidos se siguen publicando en pdf (en 2011, el 63,2\%) y el resto, principalmente, en formatos aptos para dispositivos de tinta electrónica. Es decir, que se echa en falta aún la producción de verdaderos libros electrónicos, y no meras conversiones de ficheros antiguos en pdf de imprenta, que son poco útiles en la mayoría de los casos para su utilización y visualización en dispositivos electrónicos (Gil; Rodríguez; 2011).

\section{Tabla 4}

\begin{tabular}{|l|c|}
\hline \multicolumn{2}{|c|}{ Datos de edición durante 2011 en España } \\
\hline & Datos correspondientes a 2011 \\
\hline Total de títulos editados & 83258 \\
\hline Títulos editados en formato digital & 40328 \\
\hline Títulos digitalizados del fondo del catálogo & 81169 \\
\hline
\end{tabular}

Fuente: Federación de Gremios de Editores de España, 2011b

Si analizamos la tendencia de los grandes editores internacionales también podemos apreciar un importante crecimiento de la edición en formatos digitales, y de la facturación asociada a su comercialización. De hecho, mientras que el volumen total de facturación del libro impreso disminuye, el digital aumenta, lo que supone, en general, un aumento de la facturación total de estas editoriales (Tabla 5). 
Del libro electrónico y las bibliotecas digitales...

Tabla 5

\begin{tabular}{|l|c|c|c|c|c|c|c|}
\hline \multicolumn{5}{|c|}{ Facturación de libro impreso frente al electrónico de diferentes sellos editoriales internaciona- } \\
les.
\end{tabular}

Fuente: Sales of e-books, 2013

En definitiva, el papel del editor es fundamental en la creación y conversión de obras en formatos digitales, pero no por ello han de quedar en sus manos todas las iniciativas en este sentido. Las administraciones públicas deben fomentar la apuesta por lo digital, aunque actualmente las cifras de facturación no acompañen en España. Del esfuerzo que se realice en este periodo, que podemos denominar de transición, depende que se asegure la pervivencia y pujanza de un sector básico para nuestra economía.

Todo ello a pesar de que la figura del editor está siendo cuestionada más que nunca debido a la proliferación de plataformas de autoedición que le permiten al usuario generar sus propios libros electrónicos e incluso que éstos puedan ser impresos bajo demanda. Para justificar la falta de necesidad de los editores se alude a los éxitos de ventas de algunas obras autoeditadas que inicialmente fueron rechazadas por distintos sellos editoriales. Tenemos el ejemplo de Amanda Hocking, que colgó varias de sus novelas en 
la tienda Amazon a través de su plataforma de autoedición y logró la venta de más de un millón de ejemplares (Corroto, 2011). Algo similar le ocurrió al escritor norteamericano John Locke, quien también logró la venta de más de un millón de ejemplares de su obra autoeditada (Un escritor autoeditado, 2011).

Estos casos debemos considerarlos como excepciones. Sobre todo si tenemos en cuenta que de los miles de obras autoeditadas sólo logra el éxito un porcentaje ínfimo (que además, a la larga, acaba distribuyéndose por los cauces tradicionales; es decir, a través de un editor). El papel del editor como conocedor de las tendencias del mercado, y con su capacidad de darle forma a los textos, seleccionarlos por su interés, y además ofrecer el valor añadido de su corrección estética, etcétera, va a cobrar aún más valor en un momento en el que cualquiera puede publicar lo que desee de una forma muy sencilla. Los lectores finales valorarán más que nunca que se haya realizado un proceso editorial en los contenidos que lee en digital o que adquiere en soportes tradicionales como una apuesta segura.

Sobre la lectura

En relación con la lectura lo interesante es conocer al usuario del siglo XXI. Aquí coincidimos con David Felipe Arranz, quien presenta a aquél como: "eminentemente adaptativo que mide el valor de consecuencias prácticas del texto" (Arranz, 2013).

Las preguntas actuales del usuario se relacionan sobre todo con el tiempo que tarda en encontrar una información en la red y si lo que va a encontrar o encuentra le sirve de manera práctica. Para ello se hace imprescindible saber navegar en el sentido más amplio del término, es decir, no sólo conocer los aparatos sino tener claro lo que queremos buscar. Y además están las redes, que exigen una conexión permanente para estar informado. Es aquí donde algunos teóricos afirman que las nuevas generaciones de lectores ya no leen de igual modo: es la diferencia entre la lectura lineal tradicional y una lectura mucho más selectiva en la que predominan los textos hipervinculados propios de la web. Sin 
embargo, esto no es totalmente cierto; es evidente que las definiciones de Wikipedia, los artículos periodísticos de la Red, las entradas de blogs o foros, los contenidos de páginas web, etcétera, no se leen completos. Pero tampoco en todos los casos se han leído de forma íntegra los periódicos convencionales y las entradas de diccionarios y enciclopedias impresas. Ahora bien, en cuanto a la literatura y a los textos científicos la cuestión es diferente. No creemos que el enorme desarrollo cultural y científico sea fruto de lecturas sesgadas de los textos. Y también surgen dudas de que el futuro desarrollo de literatura y ciencia universales que ha estado vinculado de forma inseparable a la cultura escrita y a la lectura lineal vaya a sufrir cambios significativos. Simplemente, y como es lógico, esta evolución imparable de ciencias y artes se sirve de la tecnología para aumentar su difusión y facilitar su uso.

Por tanto, en la lectura el artilugio y la tecnología son sólo eso, y de nuevo Arranz (2013) lo describe con precisión: "Sólo aquellos capaces de superar el formato en el encuentro con el texto podrán disfrutar de sus tesoros: ese es el reto actual. A fin de cuentas la experiencia con el misterio poético es lo que realmente importa".

Pero es cierto que la lectura ya no es patrimonio sólo de la lengua escrita, debido a la inclusión de sonidos, imágenes, videos y otros documentos en formatos digitales, aunque las claves seguirán siendo el contenido y la demanda de éste, es decir, la investigación y la creación, o la necesidad de saber. La valoración del impacto de las tecnologías en la lectura tiene luces y sombras. La digitalización de contenidos ha sacado a la luz una gran cantidad de información que permite enriquecer las bibliotecas con libros, artículos científicos y divulgativos, accesibles desde cualquier punto y en cualquier momento. Esta consideración se ha repetido y se repite hasta la saciedad, y a fuerza de leerla y escucharla hemos llegado a creerlo. Sin embargo, los teóricos, al tiempo que afirman lo que acabamos de exponer, utilizan el verbo en futuro, refiriéndose a una revolución que "permitirá" llevar el conocimiento a quienes no tienen acceso a la información y a la cultura. Hace tiempo que el futuro ya es presente, e incluso pa- 
sado, porque la información desborda hasta el extremo de aceptar la "lectura diagonal", o selectiva; es decir, de aquellos párrafos que tienen interés. Por consiguiente podemos sacar la conclusión de lecturas no asimiladas, sin profundizar en los contenidos y sin reflexión. Otra de las luces es la interacción de los lectores, la socialización, un aspecto que las editoriales han aprovechado para el marketing. Los espacios para el intercambio de experiencias son numerosos, tanto las redes generalistas como los portales, webs o blogs especializados.

\section{EJEMPLOS DE BIBLIOTECAS DIGITALES: COMPARTIR CONOCIMIENTO}

Ya hemos citado el Proyecto Gutenberg como una de las primeras iniciativas de crear una colección de contenidos digitales accesibles desde la Red y a texto completo. Sin embargo, ahora nos centraremos en algunas de las iniciativas que se han puesto en marcha en España, donde veremos cómo desde el ámbito universitario ha habido una enorme participación en el desarrollo de estos proyectos.

El proyecto más veterano es el iniciado en 1998 por la Universidad de Alicante de crear un fondo virtual de obras clásicas en lenguas hispánicas con una estructuración de contenidos análoga a una biblioteca convencional pero sin una existencia física. Así surgió la Biblioteca Virtual Miguel de Cervantes en 1999 (Figura 3), que pronto recibió el apoyo de diferentes organismos como el Banco Santander o la Fundación Botín. Hoy, gracias a los diferentes organismos que la configuran y de los que forman parte algunas de las más prestigiosas personalidades de la cultura hispánica como Mario Vargas Llosa (presidente del patronato de la Fundación Biblioteca Virtual Miguel de Cervantes), podemos afirmar que es un proyecto que goza de gran apoyo institucional y se asegura la calidad de los contenidos puestos a disposición del público (la importancia de este proyecto está en la calidad de los 
contenidos y no tanto en la cantidad) (Biblioteca Virtual Miguel de Cervantes, 2012).

Figura 3

Biblioteca Virtual Miguel de Cervantes.

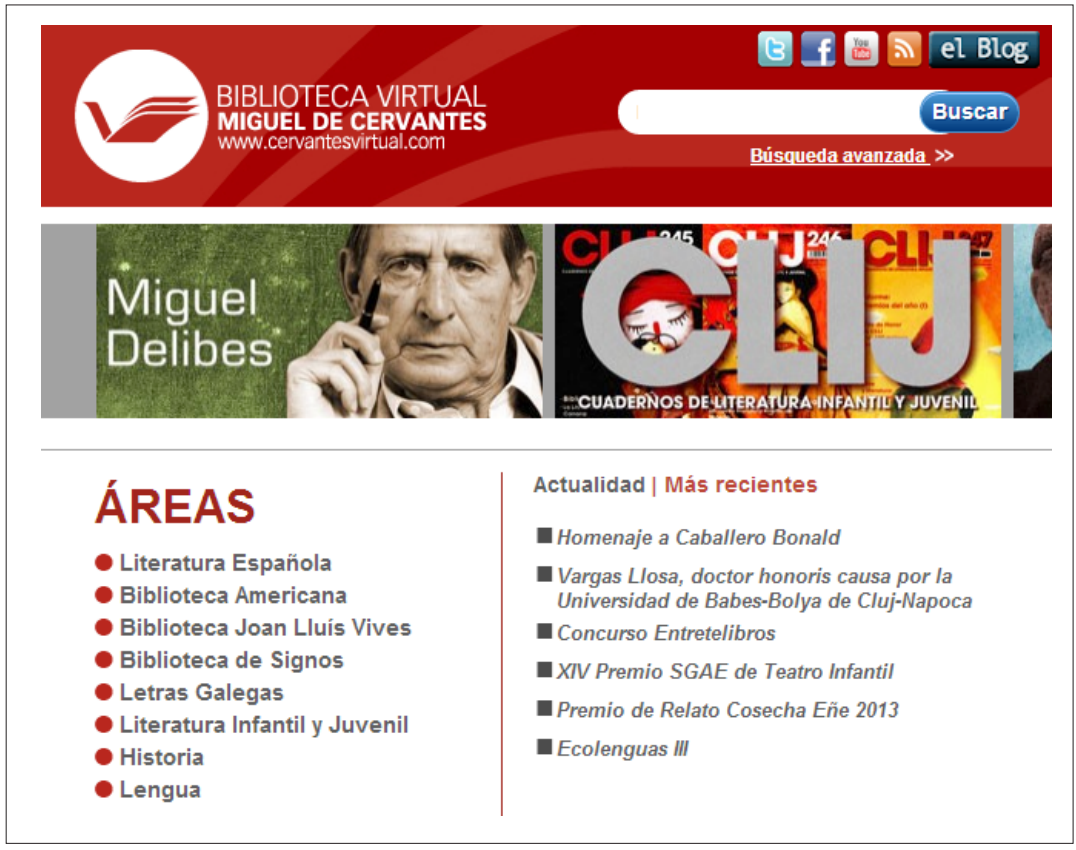

Fuente: http://www.cervantesvirtual.com

La Biblioteca Digital Hispánica (Figura 4) es la apuesta de la Biblioteca Nacional de España por crear una colección de contenidos digitales accesibles. Su lanzamiento se produjo en 2008 y entre los objetivos de su creación se encuentran la difusión del patrimonio cultural español; la contribución en la creación de la Biblioteca Digital Europea; fomentar la investigación cultural, y ofrecer un canal de cooperación al resto de bibliotecas españolas y latinoamericanas. Actualmente incorpora cerca de 100000 títulos de material bibliográfico, grabados, fotografías, registros sonoros, etcétera (Biblioteca Digital Hispánica, 2012). 
Biblioteca Digital Académica en Bibliotecología...

Figura 4

Biblioteca Digital Hispánica.

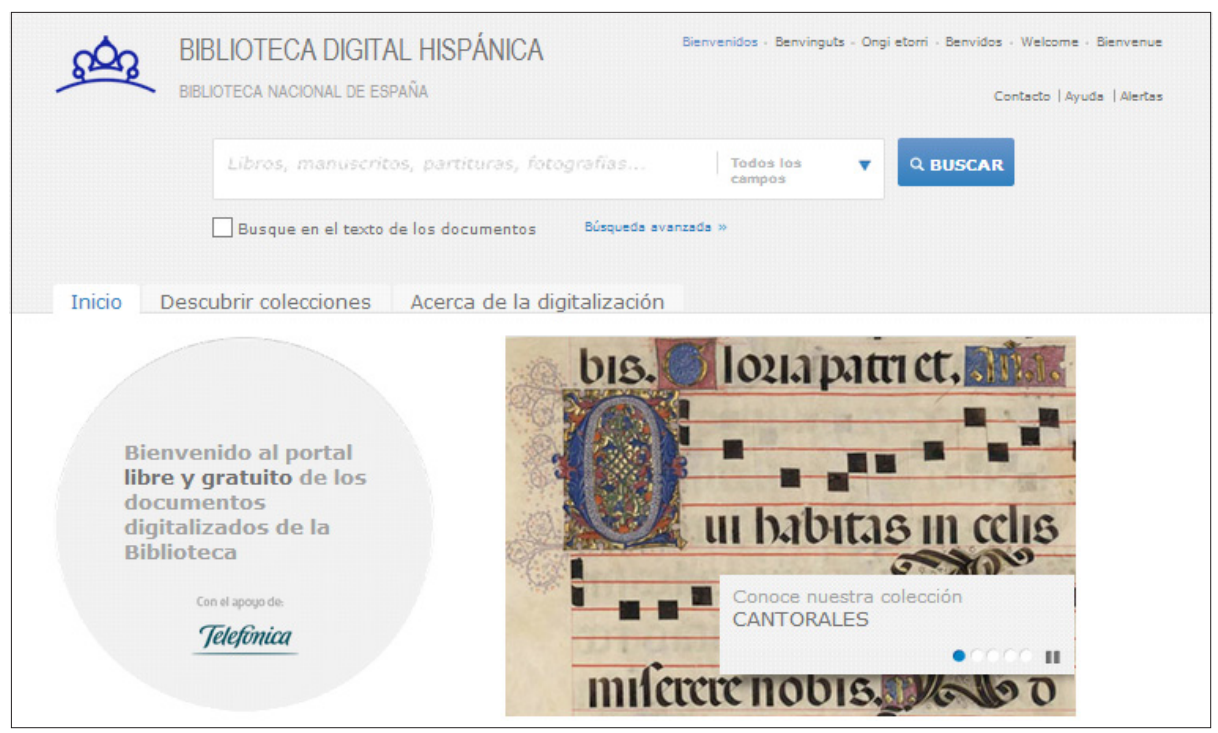

Fuente: http://www.bne.es/es/Catalogos/BibliotecaDigitalHispanica/lnicio/

En el ámbito universitario son varios los ejemplos de instituciones que han creado sus propias bibliotecas digitales. Podemos destacar las iniciativas de la Universidad Complutense de Madrid y de la Universidad de Barcelona. La primera comenzó con la digitalización y creación de la Biblioteca Digital Dioscórides en 2005 (Figura 5), cuya finalidad es la de hacer accesible el fondo histórico de la universidad. Actualmente la componen cerca de 3000 libros y en torno a 47000 grabados e ilustraciones. Inicialmente comenzó como un proyecto aislado, pero hoy esta iniciativa se encuadra en un proyecto más amplio de puesta a disposición de contenidos digitales: la Colección Digital Complutense (Colección Digital Complutense, 2012). 
Del libro electrónico y las bibliotecas digitales...

Figura 5

Biblioteca Digital Dioscórides en el marco de la Colección Digital Complutense.

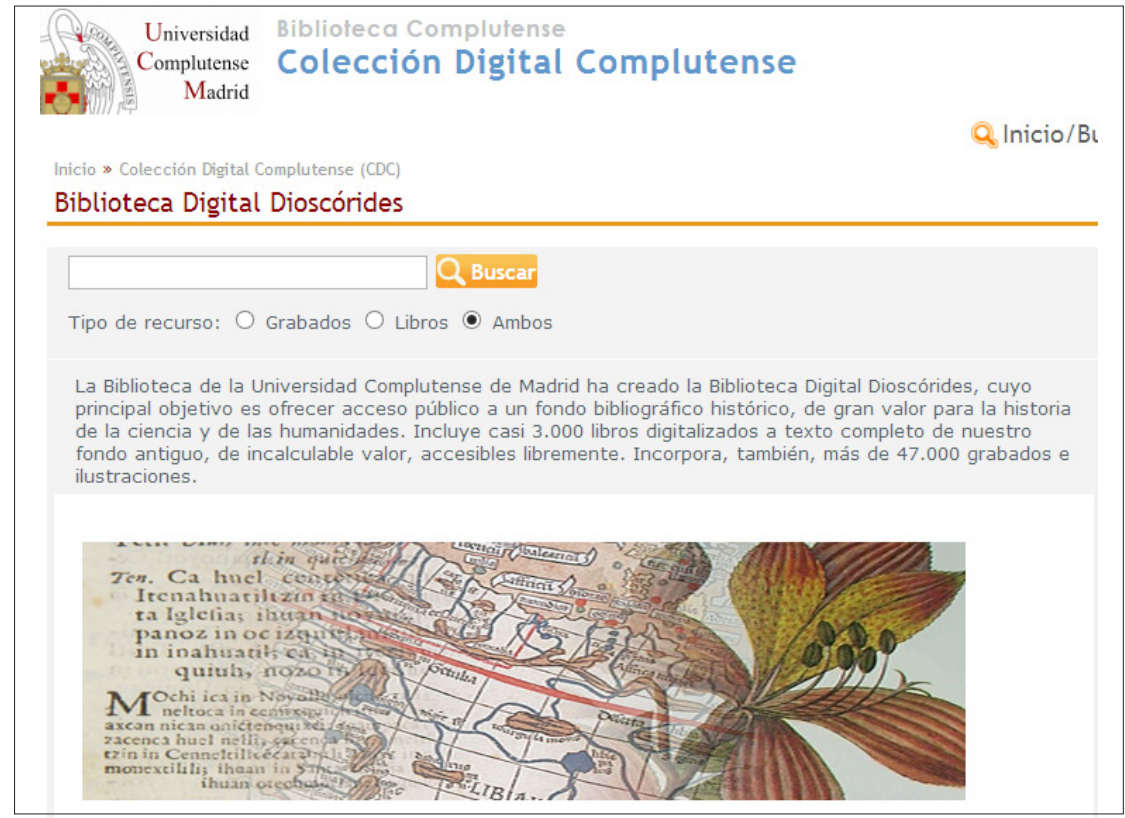

Fuente: http://biblioteca.ucm.es/atencion/24063.php

Por su parte la Universidad de Barcelona cuenta con un Centro de Recursos para el Aprendizaje y la Investigación en el que se integran una serie de colecciones digitales de gran importancia (Figura O) y que son fruto de la labor de digitalización y puesta a disposición de la Universidad. Incluye 25 colecciones de documentos entre las que destaca el fondo bibliográfico antiguo de la institución que se encuentra integrado en la Biblioteca Virtual Miguel de Cervantes (Colecciones Digitales de la Universidad de Barcelona, 2012). 
Figura 6

Colecciones Digitales de la Universidad de Barcelona.

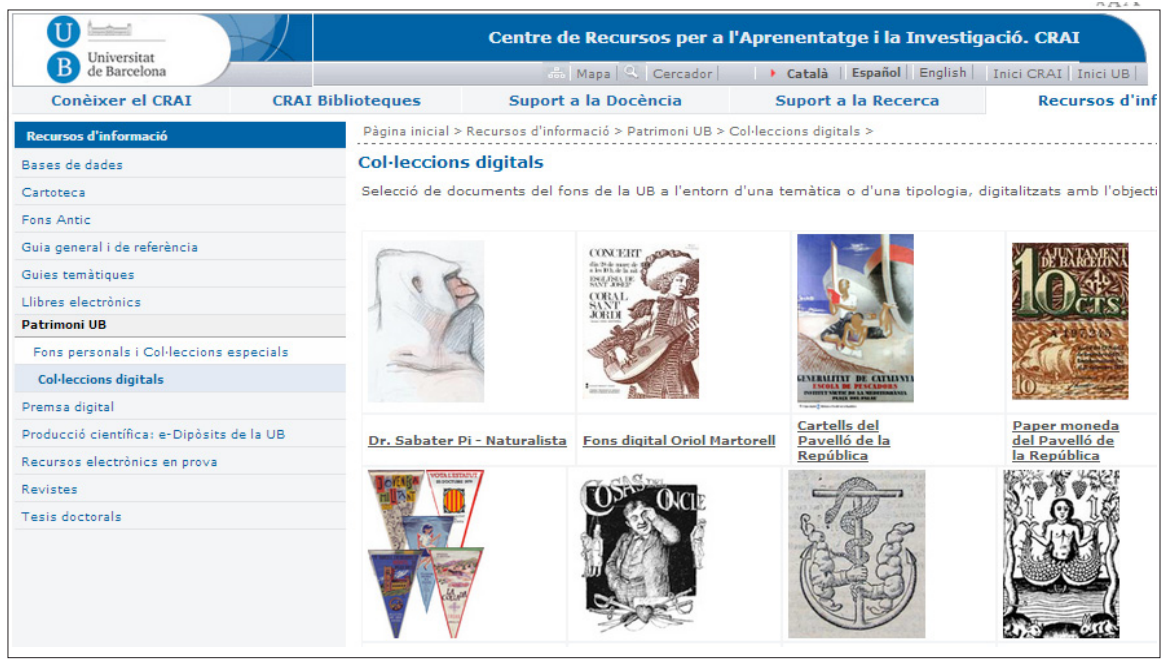

Fuente: http://www.bib.ub.edu/?id=250

Hispana es un agregador de contenidos que reúne las colecciones digitales de 195 organismos entre los que se encuentran archivos, bibliotecas y museos, y ha recogido más de cuatro millones de objetos digitales. Hispana se enmarca en la iniciativa de "Archivos Abiertos", encabezada por la Unión Europea. Entre sus funciones se encuentra la de proporcionar contenidos para otro agregador: Europeana. Forman parte de Hispana (Figura 7) los repositorios institucionales de universidades, así como las bibliotecas digitales de las Comunidades Autónomas, desde las que se accede a materiales diversos del patrimonio: manuscritos, impresos, fotografías, etcétera (Hispana, 2012). 
Figura 7

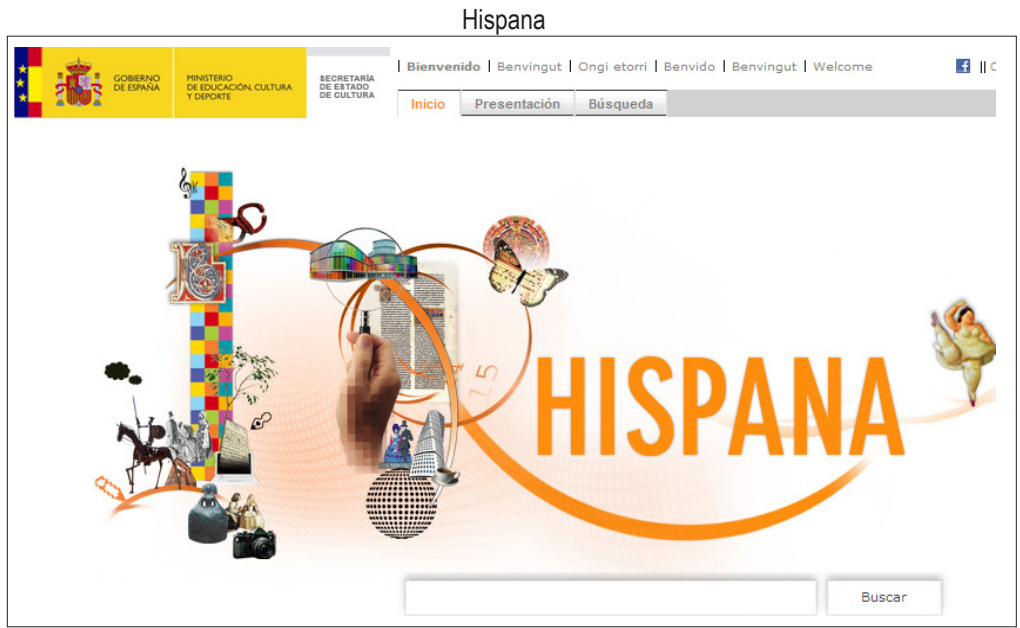

Fuente:http://hispana.mcu.es/es/estaticos/contenido.cmd?pagina=estaticos/presentacion

Estos cinco son tan sólo algunos ejemplos de entre las decenas de bibliotecas digitales que han proliferado en los últimos años en España. En general se aprecia que las bibliotecas digitales institucionales, sobre todo las de los grandes centros educativos y depositarios de la cultura, hayan evolucionado hasta convertirse en portales de contenidos digitales en general, no sólo orientados al material bibliográfico y en los que se muestran colecciones de materiales relacionados con el patrimonio cultural. Evidentemente estas plataformas de consulta y acceso a los objetos digitales son fundamentales para fomentar la cultura y facilitar herramientas para la investigación. Pero también creemos que se desvirtúa el concepto de biblioteca digital, que debería guardar más similitudes con el concepto tradicional de biblioteca. En este sentido, es posible que la evolución del término biblioteca digital siga en el futuro dos caminos paralelos: por un lado, el de sinónimo de colección de recursos digitales, y por otro, el de OPAC con servicios extendidos: acceso a los artículos de las publicaciones periódicas, al texto completo de monografías y búsquedas mediante herramientas de descubrimiento. 
Varias bibliotecas españolas, especialmente universitarias, están trabajando ya en proporcionar portales con este último planteamiento, aunque aún son muchos los contenidos que tienen en el impreso su único soporte y, evidentemente, no es posible proporcionar el acceso al texto completo. Por nuestra vinculación con la Universidad Complutense de Madrid queríamos mostrar una vez más esto a lo que nos referimos utilizando el ejemplo de la biblioteca universitaria. Durante 2012, la Biblioteca Complutense ha destacado el acceso a los diferentes recursos a través de una herramienta de búsqueda que ha bautizado "Bucea". Este servicio permite realizar consultas simultáneas en bases de datos científicas, en colecciones de recursos y en el propio catálogo de la biblioteca ofreciendo al usuario toda una batería de opciones para filtrar y ordenar los resultados. Hasta tal punto se da importancia a este acceso que el catálogo tradicional de la biblioteca "Catálogo Cisne" ha quedado en un segundo plano como puede apreciarse en la Figura 8.

Figura 8

Página principal de la Biblioteca Complutense

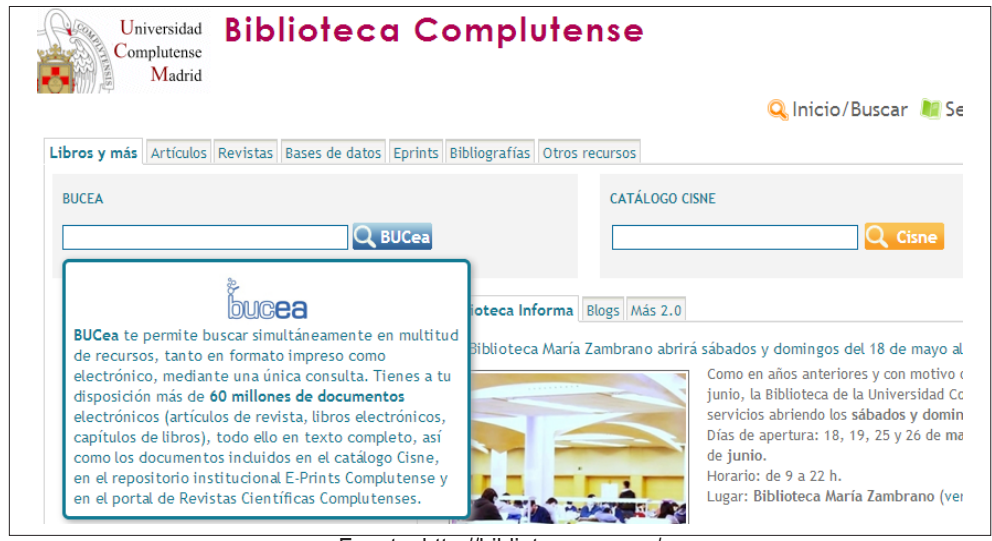

Fuente: http://biblioteca.ucm.es/

Por último queríamos mostrar algunos ejemplos de bibliotecas digitales junto con el año en el que fueron fundadas (Tabla ๑). Hemos seleccionado principalmente bibliotecas españolas in- 


\section{tercalando algunas iniciativas internacionales relevantes. Por su- puesto, ni son todas ni seguramente las más importantes, pero sí algunas de las que nos han parecido más interesantes.}

Tabla 6.

\begin{tabular}{|c|c|c|c|}
\hline \multicolumn{4}{|c|}{ Cuadro de bibliotecas digitales } \\
\hline Nombre & Creado & Organismo responsable & URL \\
\hline Proyecto Gutenberg & 1971 & Proyecto Gutenberg & http://www.gutenberg.org \\
\hline $\begin{array}{l}\text { Biblioteca Virtual Miguel de } \\
\text { Cervantes }\end{array}$ & 1999 & $\begin{array}{l}\text { Fundación Biblioteca Virtual Miguel de } \\
\text { Cervantes }\end{array}$ & http://www.cervantesvirtual.com/ \\
\hline Biblioteca Digital de Cataluña & 1999 & $\begin{array}{l}\text { Consorci de Biblioteques Universi- } \\
\text { tàries de Catalunya (CBUC) }\end{array}$ & http://www.cbuc.cat/ \\
\hline Wikisource & 2003 & Fundación Wikimedia & http://es.wikisource.org \\
\hline Biblioteca Valenciana Digital & 2003 & Generalitat Valenciana & $\begin{array}{l}\text { http://bv2.gva.es/es/cms/elemen- } \\
\text { to.cmd?id=estaticos/ }\end{array}$ \\
\hline $\begin{array}{l}\text { Biblioteca Digital de la Comunidad } \\
\text { de Madrid }\end{array}$ & 2003 & Comunidad de Madrid & $\begin{array}{l}\text { http://www.bibliotecavirtualma- } \\
\text { drid.org }\end{array}$ \\
\hline Biblioteca Digital de Andalucia & 2003 & Junta de Andalucia & $\begin{array}{l}\text { http://www.bibliotecavirtualdean- } \\
\text { dalucia.es/ }\end{array}$ \\
\hline Google Books & 2004 & Google & http://books.google.com/ \\
\hline Colección Digital Complutense & 2005 & Universidad Complutense de Madrid & http://biblioteca.ucm.es/ \\
\hline European Library & 2005 & $\begin{array}{l}\text { Conference of European National } \\
\text { Librarians (CENL) }\end{array}$ & http://www.theeuropeanlibrary.org \\
\hline $\begin{array}{l}\text { Biblioteca Digital del Real Jardín } \\
\text { bontánico }\end{array}$ & 2005 & $\begin{array}{l}\text { Consejo Superior de Investigaciones } \\
\text { Científicas (CSIC) }\end{array}$ & http://bibdigital.rjb.csic.es/ \\
\hline Digital CSIC & 2006 & $\begin{array}{l}\text { Consejo Superior de Investigaciones } \\
\text { Científicas (CSIC) }\end{array}$ & http://digital.csic.es/ \\
\hline Memoria Digital de Cataluña & 2006 & $\begin{array}{l}\text { Consorci de Biblioteques Universi- } \\
\text { tàries de Catalunya (CBUC) }\end{array}$ & http://mdc1.cbuc.cat/index.php \\
\hline $\begin{array}{l}\text { Fondos Digitalizados de la Univ. } \\
\text { de Sevilla }\end{array}$ & 2007 & Universidad de Sevilla & http://fondosdigitales.us.es/ \\
\hline Biblioteca Digital Hispánica & 2008 & Biblioteca Nacional de España & $\begin{array}{l}\text { http://www.bne.es/es/Catalogos/ } \\
\text { BibliotecaDigitalHispanica/ }\end{array}$ \\
\hline Europeana & 2008 & $\begin{array}{l}\text { Conference of European National } \\
\text { Librarians (CENL) }\end{array}$ & http://www.europeana.e/u/portal/ \\
\hline $\begin{array}{l}\text { Biblioteca Virtual del Patrimonio } \\
\text { Bibliográfico }\end{array}$ & 2008 & $\begin{array}{l}\text { Ministerio de Educación, Cultura y } \\
\text { Deporte (España) }\end{array}$ & http://bvpb.mcu.es/es/estaticos/ \\
\hline Biblioteca Digital Mundial & 2009 & Congreso de EEUU & http://www.wdl.org/es/ \\
\hline $\begin{array}{l}\text { Biblioteca Virtual de Prensa His- } \\
\text { tórica }\end{array}$ & 2009 & $\begin{array}{l}\text { Ministerio de Educación, Cultura y } \\
\text { Deporte (España) }\end{array}$ & http://prensahistorica.mcu.es \\
\hline Hispana Digital & 2010 & Consejo de Cooper. Bibliotecaria & http://hispana.mcu.es \\
\hline Biblioteca Digital Vasca & 2011 & Gobierno Vasco & http://www.liburuklik.euskadi.net/ \\
\hline
\end{tabular}




\section{REFERENCIAS BIBLIOGRÁFICAS}

Amat, N. (1990), La biblioteca electrónica, Madrid: Pirámide.

Arranz, D. F. (2013), "Literatura y nueva tecnologías", en Mercurio, 151, Sevilla: Fundación José Manuel Lara, pp. 6-7.

Biblioteca Digital Hispánica, (2012), disponible en: http://www.bne. es/es/Catalogos/BibliotecaDigitalHispanica/Inicio/index.html.

Biblioteca Virtual Miguel de Cervantes, (2012), disponible en: http:// www.cervantesvirtual.com.

Breeding, M. (2012), "Tendencias actuales y futuras en tecnologías de la información para unidades de información", en: El Profesional de la Información, v. 21, n. 1, pp. 9-15.

Bush, V. (1945), “As we think", en: Atlantic Monthly, julio de 1945.

"Cae la demanda de ereaders a favor de las tabletas" (2013), en: Boletín del Observatorio de la Lectura y el Libro, n. 13, febrero de 2013, p. 18, disponible en: http://www.mcu.es/libro/docs/MC/ Observatorio/pdf/BOLL_13_feb2013.pdf.

Colección Digital Complutense (2012), disponible en: http://biblioteca.ucm.es/atencion/5761.php.

Colecciones Digitales de la Universidad de Barcelona (2012), disponible en: http://www.bib.ub.edu/recursos-informacio/colleccions/colleccions-digitals/.

Cordón García, J. A. (2011), La revolución del libro electrónico, Barcelona: UOC. 
Cordón García, J. A.; Gómez Díaz, R.; Alonso Arévalo, J. (2011), "Libros electrónicos: oferta comercial y redes p2p", en: El Profesional de la Información, v. 20, n. 2, pp. 149-158.

Corroto, P. (2011), "El best seller digital que se convirtió al papel", (2013), en: Público.es, 10/11/2011, disponible en: http://www. publico.es/culturas/406015/el-best-seller-digital-que-se-convirtioal-papel.

"E Ink Corporation's Inmedia technology to eventually be used in electronic publishing" (1999), en: Internet Publishing Today, jul.ago., 1999, p. 33.

Eco, U. (1998), "Epílogo”, en Nunberg, G. (comp.), El futuro del libro: ¿esto matará eso?, Barcelona: Paidós.

"El préstamo de libros electrónicos en las bibliotecas de EEUU crece un 200\%", (2011), en: Lainformación.com, 18/10/2011, disponible en: http://noticias.lainformacion.com/ciencia-y-tecnologia/ tecnologia-general/el-prestamo-de-libros-electronicos-en-las-bibliotecas-de-eeuu-crece-un-200_AXTqLWyW8Gxpa2pXFsXkk2/.

"España, líder europeo en "smartphone" (2012), en: $E l$ País, 18/12/2012, disponible en: http://tecnologia.elpais.com/tecnologia/2012/12/18/actualidad/1355845983_394482.html.

Federación de Gremios de Editores de España (2011), Barómetro de Hábitos de Lectura y Compra de Libros de 2011, disponible en: http://www.federacioneditores.org/0_Resources/Documentos/ Habitos_lectura_CompraLibros_2011.pdf.

Federación de Gremios de Editores de España (2011b), Comercio interior del libro en España, disponible en: http://www.federacioneditores.org/0_Resources/Documentos/Comercio_Interior_2011.pdf. 
Federación de Gremios de Editores de España (2012), Barómetro de Hábitos de Lectura y Compra de Libros de 2012, disponible en: http://cdn.20minutos.es/adj/2013/02/07/2076.pdf.

Federación de Gremios de Editores de España (2013), Hábitos de lectura y compra de libros en España 2012, disponible en: http:// www.federacioneditores.org/0_Resources/Documentos/HabitosLecturaCompraLibros2012ESP_310113_1.pdf.

García Melero, L. A.; García Camarero, E. (1999), Automatización de bibliotecas, Madrid: Arco.

Gil, M.; Rodríguez, J. (2011), El paradigma digital y sostenible del libro. Madrid: Trama.

Gutiérrez, J. B.; Marino, M. C.; Gervás, P.; Borràs Castanyer, L. (2009), "Electronic Literature as an Information System", en: Hyperrbiz: new media cultures, 2009, n. 6, disponible en: http://www.hyperrhiz.net/hyperrhiz06/19-essays/74-electronic-literature-as-aninformation-system.

Hispana (2012), disponible en: http://hispana.mcu.es/es/estaticos/ contenido.cmd?pagina $=$ estaticos/presentacion.

Hart, M. (1992), "The History and Philosophy of Project Gutenberg", disponible en: http://www.gutenberg.org/wiki/Gutenberg:The History_and_Philosophy_of_Project_Gutenberg_by_Michael_ Hart.

Kay, A., Goldberg, A. (1977), "Personal Dynamic Media", en: Computer, n. 10 (3), pp. 31-41.

La sociedad de la información en España 2012. (2013), Barcelona: Ariel, Fundación Telefónica, 2013, 186 p., disponible en: http://elibros.fundacion.telefonica.com/sie12/aplicacion_sie/ParteA/pdf/ SIE_2012.pdf. 
Lebert, E. (2009), Una corta historia del ebook, Toronto: Universidad de Toronto, disponible en: http://www.etudes-francaises.net/dossiers/ebookES.pdf (consultado el 11 de septiembre de 2011).

Ley 23/2011, de 29 de julio, de depósito legal, http://www.boe.es/ diario_boe/txt.php?id=BOE-A-2011-13114.

Ley 10/2007, de 22 de junio, de la lectura, del libro y de las bibliotecas, http://www.boe.es/diario_boe/txt.php?id=BOE-A-2007-12351.

López Yepes, J. (ed.) (2004), Diccionario Enciclopédico de las Ciencias de la Documentación, Madrid: Pirámide.

Monteoliva, E.; Pérez-Ortiz, C.; Repiso, R. (2008), "Lectores de documentos electrónicos", en: El Profesional de la Información, v. 17, n. 4, pp. 396-402.

Project Gutenberg (2011), disponible en: http://www.gutenberg.org.

"Sales of e-books rose again in 2012, but print slide slowed" (2013), en: Publishers Weekly, 12/04/2013, disponible en: http://www.publishersweekly.com/pw/by-topic/digital/retailing/article/56806more-than-a-digital-book-world.html.

Salmon, S. R. (1975), "Library automation”, en: Kent, A.; Lancour, H. Y Daily, J. E. (eds.), Encyclopedia of library and information science, New York: Marcel Dekker, v. 14, pp 338-445.

Sánchez Vigil, Juan Miguel (2009), La edición en España: industria cultural por excelencia. Historia, proceso, gestión, documentación, Gijón: Trea.

Saorín Pérez, T. (2002), Modelo conceptual para la automatización de bibliotecas en el contexto digital, Tesis doctoral. Universidad de Murcia, disponible en: http://tdx.cat/bitstream/handle/10803/10903/SaorinPerez.pdf?sequence $=1$. 
Selburn, J. (2012), "Ebook Readers: Device to Go the Way of Dinosaurs?: Shipments are on a fast decline, overwhelmed by tablets", en : IHS iSuppli, 2012, disponible en http://www.isuppli.com/ Home-and-Consumer-Electronics/MarketWatch/Pages/EbookReaders-Device-to-Go-the-Way-of-Dinosaurs.aspx.

"Situación actual y perspectivas del libro digital en España II: La producción española de libros digitales y su distribución y venta en la Red" (2012), Ministerio de Educación, Cultura y Deporte, Observatorio de la Lectura y el Libro, 2012, disponible en: http:// www.mcu.es/libro/docs/MC/Observatorio/pdf/situacion_librodigital_2.pdf.

Tornel Cobacho, C.; Sánchez Martínez, C. E. (2012), "La gestión del libro electrónico en la red de bibliotecas municipales de Cartagena”, en: Actas del VI Congreso Nacional de Bibliotecas Públicas. Madrid: Ministerio de Educación, Cultura y Deporte, disponible en : http://www.mcu.es/bibliotecas/docs/MC/2012/CongresoBP/ Comunicaciones/Lagestiondellibroelectronico.pdf.

United States Congress (2011), The Congressional International AntiPiracy Caucus, disponible en: http://infojustice.org/wp-content/ uploads/2011/06/iapc-watchlist2011.pdf 2011.

Valentín Ruiz, F. J. (2011), "El libro electrónico en España. Políticas de actuación", en: Actas VIII Seminario Hispano-Mexicano de Biblioteconomía y Documentación, Madrid, Universidad Complutense, 2011, págs. 289-302, disponible en: http://eprints.ucm. es/16031/1/El_libro_electronico.pdf.

Valentín Ruiz, F. J.; Fernández Sánchez, A. B.; Torre-Marín, R. (2012), "Servicios cloud computing para la gestión de bibliotecas: hacia un nuevo modelo", en Actas del и Congreso Nacional de Bibliotecas Públicas, Madrid: Ministerio de Educación Cultura y Deporte, 2012, disponible en: http://www.mcu.es/bibliotecas/docs/MC/2012/CongresoBP/Comunicaciones/Servicioscloudcomputing.pdf. 
Vaughan, J. (2011), "Web Scale Discovery Services”, en: Library Technology Reports (American Library Association), Vól. 47, Núm. 1.

Vázquez, A.; Celaya, J. (2012), Cronología de la edición digital: 19122012: 100 años de evolución tecnológica, Dosdoce.com, 2012, disponible en http://www.mcu.es/libro/docs/MC/Observatorio/pdf/ cronologia_ediciondigital.pdf.

Wattpad Global Ebook Metrics Report (2010), disponible en: http:// anatomiteca.com/wpcontent/uploads/2011/09/Wattpad_Global_ Ebook_Metrics_Report_Q2_2010.pdf. 


\title{
Linked Open Data en la Biblioteca Digital Semántica Académica
}

\author{
EDER ÁVILA BARRIENTOS \\ Universidad Nacional Autónoma de México
}

\section{INTRODUCCIÓN}

E 1 objetivo que persigue este documento recae en describir y analizar la aplicación de Linked Open Data (LOD: Datos Abiertos Vinculados) en el entorno de las bibliotecas digitales semánticas.

La Biblioteca Digital Semántica Académica (BDSA) es el resultado del desarrollo de las Tecnologías de la Información y la Comunicación (TIC); su relación con el entorno digital se ha consagrado principalmente con su presencia en la Web y, con ello, se ha propiciado una serie de desarrollos en las actividades bibliotecarias, educativas, sociales, culturales y de investigación.

La BDSA se puede concebir como un sistema accesible a través de la Web semántica, integrado por una serie de componentes y que forma parte o es patrocinado por una institución académica de nivel superior. Por lo tanto, apoya los planes y programas de estudio de dicha institución y, como objetivo principal, busca satisfacer las necesidades de información de la comunidad académica. Para ello, ofrece colecciones y servicios digitales diseñados para estar comprendidos en un abanico muy grande de posibilidades y opciones, lo cual deriva de la amplia variedad de perfiles informativos presentes en la cada vez más demandante comunidad académica. 
Este documento presenta un marco general sobre los atributos que se ven inmersos en la aplicación del Linked Open Data, en el entorno de las bibliotecas semánticas académicas.

\section{La Biblioteca Digital Semántica Académica (BDSA)}

En la Biblioteca Semántica se reflejan las tendencias en el manejo de la información de la Web 3.0. Ryszard señala que la biblioteca digital semántica es la siguiente generación de biblioteca digital, y que muestra las siguientes características:

- Integra información de diferentes tipos de metadatos.

- Ofrece interoperabilidad con otros sistemas (no sólo entre bibliotecas digitales), en un nivel de comunicación entre metadatos.

- Permite una búsqueda más robusta y amigable, gracias a los recursos semánticos.

El enriquecimiento de las tecnologías de la Web semántica se refleja de forma más clara en el área de servicios de información. Morales del Castillo menciona que en la biblioteca digital las tecnologías de la Web semántica se aplican para desarrollar servicios de valor añadido en la definición de una descripción enriquecida, en el establecimiento de ontologías que favorecen la interoperabilidad de los recursos, en el desarrollo de interfaces de usuarios, y en mejoras en la navegación, visualización y presentación de contenidos, entre otras cuestiones. La Web semántica supone una extensión de la Web actual, donde la información está dotada de un significado bien definido, puede ser procesada por las máquinas e interpretada por los humanos, lo que permite una mejor cooperación.

Efectivamente, lo que se busca es conseguir una Web donde sea posible explicitar y explotar la interconexión de los datos que circulan por ella. En este sentido, las tecnologías de la Web se- 
mántica posibilitarían mejores búsquedas de información a través de lineamientos, propuestas y protocolos que fomenten la relación y el intercambio de información.

En la Web semántica han surgido propuestas para la integración de datos enlazados. Open Data (datos abiertos) es un término que se refiere a la manera de publicar datos de organizaciones públicas y privadas, en formatos que sean reutilizables por personas e instituciones.

\section{LOS DATOS EN EL ÁMBiTO DE LA BiBliotecA DigiTAL ACADÉmiCA SEMÁNTICA}

La generación de datos en el entorno digital es una realidad en los campos científicos y académicos. Los datos son representaciones numéricas, alfabéticas, algorítmicas, etcétera, que permiten identificar un determinado recurso de información. La riqueza de datos y las herramientas generadas para su búsqueda, análisis, recuperación y visualización, permite a los investigadores académicos interpretar cada vez mayores cantidades de datos. Los conjuntos de datos (datasets) representan a los productos finales de determinadas investigaciones, lo cual complementa notablemente el papel tradicional de las publicaciones académicas. Es decir, dichos datos les dan un valor agregado a estas publicaciones mediante la posibilidad de establecer relaciones estructuradas, significativas y que contribuyan a la colaboración en el entorno académico. Así, si los datos y recursos pueden enlazarse mediante una infraestructura de información, la investigación colaborativa y multidisciplinaria en el contexto digital será posible.

Las BDSA seleccionan, recopilan, organizan y hacen accesibles publicaciones (recursos) de diversa índole temática. Estas actividades generan una serie de datos o conjuntos de datos que son representados mediante esquemas, formatos, modelos y normas que describen los atributos físicos e intelectuales de dichas publicaciones, dando como resultado una serie de registros que son ac- 
cesibles a la comunidad usuaria mediante el uso de herramientas para el acceso y control de la información documental, como es el caso de catálogos en línea, repositorios, bases de datos y descubridores de información. Una infraestructura normalizada de información, como es el caso de la que presentan las BDSA, puede mantener vínculos entre datos, publicaciones y otras formas de comunicación científica mediante la generación de mappings.

Los registros semánticos (mappings) son representaciones codificadas de información documental que posibilitan la descripción y vinculación de datos mediante puntos de acceso claramente identificables, como las autoridades y las temáticas que identifican a una determinada publicación. Cuando estos puntos de acceso son vinculados, entonces adquieren un significado que puede favorecer la búsqueda y recuperación de información en el entorno de la investigación académica. El papel de este tipo de datos en la comunicación científica es esencial para la publicación de trabajos académicos, los cuales pueden estar disponibles a través de la biblioteca digital semántica académica.

Al momento de concebir la presencia de datos enlazados en este tipo de bibliotecas, es preciso no perder de vista las recomendaciones que se dan para el acceso, preservación y conservación de dichos datos. Actualmente, los temas de migración de datos, interoperabilidad de formatos y normas para su publicación, han tomado gran importancia debido a la búsqueda de compatibilidad que se desea alcanzar mediante medidas de preservación y conservación de los recursos digitales. Estas medidas están encaminadas a propiciar el acceso permanente a los recursos y sus respectivos datos en el entorno digital.

"La búsqueda de publicaciones académicas y sus respectivos datos puede requerir navegar a través de muchas bibliotecas digitales, motores de búsqueda, catálogos e índices”. Los investigadores dentro de un campo específico del conocimiento manejan múltiples herramientas para buscar, recuperar y acceder a la información que necesitan. En ocasiones, la localización del recurso deseado por el investigador resulta ágil y exitosa debido, primordialmente, a la normalización metodológica utilizada 
en la representación de dichos recursos. En el caso de los datos de publicaciones académicas, su localización en ocasiones se ve obstaculizada por la ausencia de una metodología que permita su pronta y satisfactoria identificación. Actualmente, en el entorno de la Web semántica, han surgido propuestas que pretenden conformar un medio para el acceso significativo a los recursos de información, tal es el caso de la propuesta de los datos enlazados.

\section{PRINCIPIOS BÁSICOS Y COMPONENTES DE LINKED OPEN DATA (LOD)}

Berners Lee definió cuatro principios básicos para la publicación de Linked data:

- Usar URI (Uniform Resource Identifiers: identificadores uniformes de recursos) para identificar los recursos de forma unívoca.

- Usar URI http para que la gente pueda acceder a la información del recurso;

- Ofrecer información sobre los recursos usando RDF (Resource Description Frame Work: Marco de Descripción de Recursos).

- Incluir enlaces a otros URI para facilitar el vínculo entre distintos datos distribuidos en la Web.

De esta manera, es viable publicar datos que cumplan sólo los tres primeros principios, pero el hecho de no aplicar el cuarto los convierte en menos visibles y, como consecuencia, menos reutilizables. Linked Open Data forma parte esencial de la concepción de la Web semántica y, por lo tanto, posee una serie de componentes que permiten la construcción de este espacio digital. A continuación presentamos estos elementos: 
- XML (Extensible Markup Language: Lenguaje Extensible de Mercado). Sintaxis superficial para documentos estructurados.

- XML Schema. Lenguaje para definir la estructura de los documentos XML.

- RDF. Modelo de datos para los recursos y las relaciones que se puedan establecer entre ellos.

- RDF Schema. Vocabulario para describir las propiedades y las clases de los recursos RDF con una semántica para establecer jerarquías de generalización entre dichas propiedades y clases.

- SPARQL. Lenguaje de consulta sobre RDF que permite hacer búsquedas sobre los recursos de la Web semántica utilizando distintas fuentes de datos.

- owl. Añade más vocabulario para describir propiedades y clases, como: relaciones entre clases, cardinalidad, igualdad, tipologías de propiedades más complejas, caracterización de propiedades o clases enumeradas.

\section{LAS CINCO ESTRELLAS DE LINKED OPEN DATA}

En 2010, Berners Lee redefinió su concepción de LD añadiendo la filosofía de la apertura, de tal forma que los datos "abiertos" enlazados (LOD) se liberan bajo una licencia abierta, no impidiendo de esta manera su libre reutilización. Utilizando la metáfora de las estrellas en los hoteles, estableció cinco niveles para medir la calidad de LOD. Las cinco estrellas de Linked Open Data son una guía para detectar el grado de reutilización de los datos abiertos enlazados:

- Una estrella: ofrece los datos en cualquier formato, aunque sean difíciles de manipular no desagregar, como un pdf por ejemplo, o una imagen escaneada.

- Dos estrellas: entregar los datos de manera estructurada, como en un archivo excel con extensión xls. 
- Tres estrellas: entregar los datos en un formato que no sea propietario, como csv, en vez de excel, xml, rdf, etcétera.

- Cuatro estrellas: usar URI (que es una dirección web de un dato que sirve para enlazarlo con otros datos) para identificar cosas y propiedades; de manera que se pueda apuntar a los datos. Requiere utilizar el estándar RDF.

- Cinco estrellas: vincular sus datos con los de otras personas, dotándolos de contexto. En la práctica, permite que la información entregada también apunte a otras fuentes de datos. Por ejemplo, si coloco un país dentro de mis datos, puedo agregar una URI de referencia que apunte a los datos de ese país en Dbpedia o a Geonames.

\section{TRIPLETES RDF}

Figura 1

Representación gráfica de un triplete

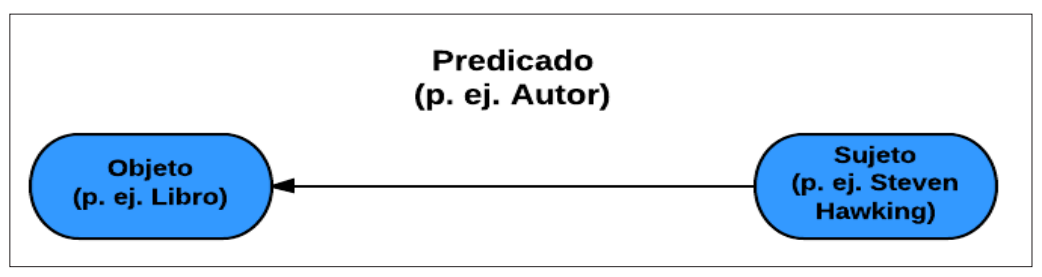

La construcción de tripletes con RDF se basa en la idea de declarar recursos usando la expresión en la forma sujeto-predicadoobjeto. Esta expresión se conoce en la terminología RDF como triple o triplete. Un triplete RDF contiene tres componentes, todos con referencia en un URI (Figura 1).

- Sujeto. Una referencia URI, una persona, o un nodo, es el ente al cual nos referimos.

- Predicado. Es la propiedad o relación que se desea establecer acerca del sujeto. 
- Objeto. Es el valor de la propiedad o del otro recurso con el que se establece la relación.

El uso de LOD hace posible publicar información migrada desde diferentes fuentes en las que se encuentra almacenada, como por ejemplo bases de datos, repositorios, hojas de cálculo, catálogos en línea, siempre y cuando se utilice el lenguaje RDF para permitir enlazar esta información con otros datos, de forma que aumente la conectividad entre dicha información y se facilite así la búsqueda, la recuperación y la agregación de información relacionada.

Esta construcción de tripletes se logra mediante la aplicación e integración de diversos componentes, que en su conjunto forman parte del modelo integral de los datos abiertos enlazados. Al conjunto de tripletes se les identifica como DataSets (o conjunto de datos). Dichos conjuntos integran un contexto en específico, el cual se relaciona con otros contextos mediante la vinculación de sus atributos. La construcción de estas relaciones tienen gran relevancia al momento de realizar una determinada búsqueda sobre un autor, recurso o tema en específico en el entorno digital.

\section{DATOS ENLAZADOS EN LA BibliotecA Digital ACADÉMICA SEMÁNTICA}

El término Linked Data (datos enlazados) se refiere al método con el que se pueden mostrar, intercambiar y conectar datos a través de URis desreferenciables en la Web. Estas dos propuestas han nacido en el marco general de la Web semántica y han propiciado los mecanismos, métodos y directrices a seguir para conformar un modelo de datos enlazados abiertos (Linked Open Data) que propicie una Web con mayor significado y mejores oportunidades en la búsqueda y acceso a la información. "Los dos conceptos clave son Open data y Linked data o Linked open data (LOD), traducible al español como datos abiertos vinculados (o enlazados). Ambos se derivan de las declaraciones del creador 
de la web, Tim Berners-Lee (2006), asesor del gobierno británico. Y además el segundo se relaciona con la familia de estándares del W3Consortium (2010) para la construcción de la web semántica”. El informe sobre datos enlazados bibliotecarios del Grupo incubadora del w3C (Library Linked Data IncubatorGroup: Datasets, ValueVocabularies, and MetadataElement Sets), es relevante para entender la oportunidad que se les abre a las bibliotecas para alcanzar el impacto digital que pretenden, además de concretar nuevos modelos en el acceso y la utilización de recursos de información digital. En este sentido, "[...] a escala internacional, el w3C identificó la comunidad bibliotecaria como uno de sus focos de interés y a través de sus Incubatorgroups -grupos dinámicos que se utilizan para detectar nuevos nichos de actuación-, creó en mayo de 2010 uno orientado a la publicación de datos estructurados en Linked data procedentes de bibliotecas". El Library Linked Data IncubatorGroup tiene como misión analizar la situación de los modelos y esquemas de metadatos y los estándares y protocolos de interoperabilidad que se deberían usar para la publicación y el uso de Linked Open Data (LOD) con datos de bibliotecas. A su vez anima a la comunidad a publicar sus registros bibliográficos y control de autoridades, como Linked Data.

Las BDSA están constituidas por colecciones y contenidos digitales. Estos elementos tienen la facultad de producir datos que pueden enlazarse, y que pueden ser útiles para la el apoyo de la investigación mediante la generación de nuevos servicios en el entorno digital. En Bibliographic Framework as a Web of Data: Linked Data Model and Supporting Services, documento realizado por la Biblioteca del Congreso de los Estados Unidos puede apreciarse la aplicación de LOD en la construcción de un marco bibliográfico basado en datos enlazados que permite, a su vez, la generación de núcleos recursos digitales de información enlazados.

Esto supone la integración de dichos recursos y LOD en el contexto de la Web semántica mediante la generación de relaciones que permitan a las bibliotecas digitales semánticas académicas enlazar sus recursos mediante los componentes de dicha Web. Los recursos de información digital presentes en esta modalidad 
de bibliotecas deberán ser descritos, organizados y enlazados mediante la adopción de modelos en sus catálogos de autoridades, bibliográficos u otras herramientas para el control y acceso a la información en el entorno digital. Estas fuentes de información pueden ser de utilidad en la generación de servicios innovadores de investigación en las bibliotecas. Así, nos referimos a la Web semántica como el contexto en donde la biblioteca digital académica y Linked Open Data pueden integrarse, y por ende, potencializar la generación de nuevos servicios de investigación mediante la innovación abierta.

\section{SERVICIOS DE INNOVACIÓN ABIERTA EN LA BDSA}

El término innovación abierta hace referencia a la apertura del proceso de investigación de una empresa a terceros. Supone delegar en agentes externos a la propia organización parte de las tareas de desarrollo de innovaciones, y compartir con ellos nuestros datos y nuestra información. En este sentido, la BDSA, mediante la incorporación de Linked Open Data en su estructura de información, propicia la apertura de procesos de investigación a sus usuarios. Este proceso resulta innovador desde el momento en que dicho usuario puede visualizar las relaciones temáticas y de autoridades que provoca la vinculación de los datos en la BDSA. La visualización de estas relaciones propiciará la conformación de redes que podrían facilitar al investigador su búsqueda y recuperación de información mediante la aplicación de la BDSA en sus procesos.

La incorporación de los servicios de la Web semántica en los de la BDSA puede ser una latente alternativa para alcanzar tal cometido. Los servicios de la Web semántica son una aplicación de la semántica y las ontologías. Utilizan la estructura XML para describir y contener aplicaciones que pueden hacerse accesibles a través de Internet.

Mediante el uso de estas tecnologías en la BDSA, sería viable la posibilidad de implementar nuevos servicios de búsqueda y recuperación de información con una arquitectura de información 
basada en datos enlazados. Actualmente, pueden observarse algunos esfuerzos por parte de las bibliotecas nacionales por incorporar nuevos servicios mediante la implementación de los datos enlazados en sus arquitecturas.

La propuesta datos.bne.es es un proyecto conjunto del OntologyEngineeringGroup (OEG) y la Biblioteca Nacional de España, destinado al enriquecimiento de la Web Semántica con datos bibliográficos provenientes de su catálogo. Esta iniciativa se ha puesto en marcha con la publicación, conforme a los principios de Linked Data, de información procedente de los catálogos bibliográficos y de autoridad, haciéndolos disponibles como bases de conocimiento RDF (Resource Description Framework). Además, estos datos se interrelacionan con otras bases de conocimiento existentes en la iniciativa Linking Open Data.

De esta manera, el proyecto de datos enlazados de la Biblioteca Nacional de España se suma a los proyectos que otras instituciones, como la Biblioteca Británica y la Biblioteca Nacional de Alemania, que han comenzado recientemente. Estos proyectos nos permiten apreciar la innovación presente en la implementación de datos enlazados en las arquitecturas de grandes bibliotecas. En el caso de la BDSA, será necesario estudiar, analizar y comprender los atributos y variables que estarán inmersos en la aplicación de los datos enlazados en su arquitectura.

\section{TENDENCIAS ACTUALES DEL USO DE DATOS ENLAZADOS COMO SERVICIO EN LAS BIBLIOTECAS DIGITALES}

La aplicación de datos enlazados en los servicios de las bibliotecas digitales ha empezado a marcar una determinada tendencia. Se observa que estos servicios se caracterizan por la implementación de nuevas plataformas tecnológicas que son accesibles a través del portal Web de las bibliotecas. Estas plataformas permiten llevar a cabo búsquedas y recuperación de información en el entorno de datos enlazados que dichas bibliotecas han creado 
con anterioridad. Por lo tanto, la implementación de datos enlazados en una determinada biblioteca requiere de una planeación en la cual intervienen una serie de tecnologías que permiten la creación de este tipo de entornos.

\section{DATOS ENLAZAdOS ABIERTOS DE LA BIBLIOGRAFÍA NACIONAL BRITÁNICA}

La Biblioteca Británica a través de sus servicios de metadatos permite apreciar la aplicación de las tecnologías de los datos enlazados en sus servicios. La Biblioteca Británica, actualmente, se encuentra desarrollando una versión de la Bibliografía Nacional Británica, que se pone a disposición de los usuarios como datos abiertos enlazados a través de una plataforma. La propuesta inicial de esta plataforma incluye datos enlazados sobre monografías y publicaciones seriadas que corresponden a las colecciones de la Biblioteca Británica (Figura 2).

Figura 2.

Modelo de datos para monografías. Biblioteca Británica.

Disponible en: http://www.bl.uk/bibliographic/pdfs/bldatamodelbook.pdf

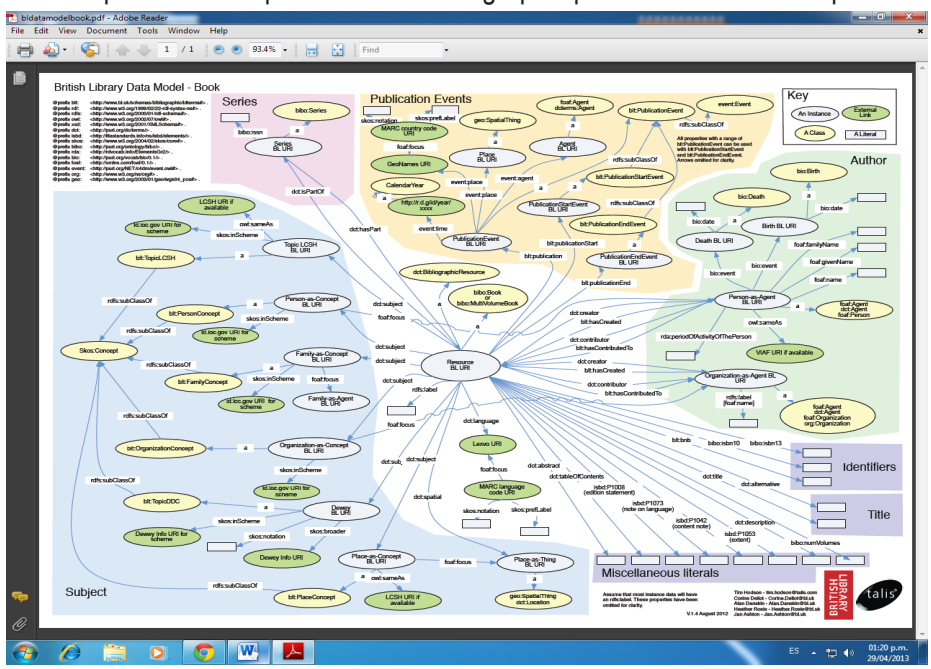


En el modelo de datos para monografías de la Biblioteca Británica, podemos apreciar el ejemplo de un recurso de información (RESOURCE BL URI) y las múltiples relaciones que pueden establecerse a través de sus atributos. Cada una de las relaciones permite descubrir nueva información a través de los atributos de un solo recurso. A su vez, puede apreciarse la categorización de estas relaciones mediante núcleos de tema, título, autor, datos de publicación y series. Cada uno de estos núcleos responde a los atributos de la monografía ejemplificada en el modelo.

\section{SERVICIO DE DATOS ENLAZADOS}

DE LA BiblioteCA NACIONAL DE ALEMANIA

A largo plazo, la Biblioteca Nacional de Alemania está planeando ofrecer un servicio de datos enlazados que permitirá a la comunidad de la Web semántica utilizar todas las existencias de sus datos bibliográficos nacionales, incluyendo sus datos de autoridad. Uno de los objetivos de este servicio es atraer a nuevos grupos de usuarios a la biblioteca; por lo tanto, el proyecto también contempla la identificación de las necesidades de información de estos usuarios. En la actualidad, se puede buscar en el portal de la Biblioteca Nacional de Alemania y se obtienen los datos enlazados a través de los vínculos de representación RDF / XML.

\section{PRESENCIA DE LINKED OPEN DATA EN EL CONTEXTO MEXICANO}

En el contexto mexicano, la presencia de Linked Open Data se manifiesta a través de una serie de proyectos y propuestas, sobre todo de carácter gubernamental. De esta forma, se propone que los datos estén disponibles de forma libre para el ciudadano. Linked Open Data se ha convertido en el mecanismo ideal para promover la Reutilización de Información del Sector Público 
(RISP), ya que este sector produce una gran variedad de información (económica, social, geográfica, meteorológica, turística, educativa) que puede ser reutilizada tanto por ciudadanos como por la iniciativa privada. Con la finalidad de mostrar los avances de Linked Open Data en nuestro país, se presentan ejemplos de los dataset (conjunto de datos) creados con información de las dependencias del país. Los dataset pueden apreciarse en el sitio Web de Datos Abiertos del Gobierno Mexicano. ${ }^{1}$

En el ámbito de desarrollo informático, en México se ha comenzado a desarrollar software de utilidad semántica, como es el caso de Semantic Web Builder, una suite de productos que sirven como plataforma para desarrollar aplicaciones y portales semánticos, creada por el Fondo de Información y Documentación para la Industria, INFOTEC, Centro de Investigación y Desarrollo Tecnológico del CONACyT.

La suite Semantic Web Builder está conformada por una serie de herramientas que permiten la evolución de los sitios Web convencionales (sin significado), hacia los portales que cumplan con la visión de la Web Semántica (con significado), lo que les permite exponer en formatos estándar como RDF todo el conocimiento generado, además de contar con un Modelo (Ontología) que permite el intercambio de esta información entre los diferentes sistemas. ${ }^{2}$

Como puede apreciarse, Linked Open Data tiene una considerable presencia en los ámbitos gubernamentales e informáticos de nuestro país. Sin embargo, carece de presencia en el entorno de las bibliotecas digitales.

1 Disponible en: http://datosabiertos.gob.mx/

2 Semantic Web Builder: Quiénes somos. Disponible en: http://www.semanticwebbuilder.org.mx/en/swb/SWB_Platform 


\section{CONSIDERACIONES FINALES}

En este estudio se ha presentado el marco teórico que sustenta la presencia de la BDSA. Se ha abordado la aplicación de los datos enlazados abiertos en los servicios de dicha biblioteca. Sin embargo, es necesario profundizar en el estudio de los elementos de la tecnología semántica que permiten la aplicación de estos datos en los servicios de las bibliotecas.

La innovación abierta se presenta a través de nuevas alternativas para la publicación, búsqueda y recuperación de información; los repositorios institucionales y las publicaciones académicas de acceso abierto son ejemplos de su aplicación en las bibliotecas.

Como hemos apreciado en este documento, los datos enlazados abiertos y su adaptación en las bibliotecas permiten la generación de servicios innovadores, basados en búsquedas y recuperación de información que tienen un mayor significado y trascendencia para el usuario.

Las relaciones entre recursos de información permitirán visualizar las redes de conocimiento construidas por diversas comunidades científicas y académicas. La visualización de redes de conocimiento a través de las plataformas de datos enlazados abiertos puede ser un apoyo para la generación de futuras investigaciones.

\section{REFERENCIAS BIBLIOGRÁFICAS}

Berners Lee, Tim, Hendler, James and Lassila, Ora, "The semantic web: a new form of Web content that is meaningful to computers will unleash a revolution of new possibilities", en: The scientific American, Vol. 284, Núm. 5, 2001, p. 35 (35-43).

Biblioteca Nacional de España, Datos enlazados en la BNE, disponible en: http://www.bne.es/es/Inicio/Perfiles/Bibliotecarios/DatosEnlazados/index.html. 
Borgman, Christine L., Scholarship in the digital age: information, infrastructure and the Internet, United States of America: MIT Press, 2007, p. 138.

Chesbrough, Henry, Open Business Models: How to Thrive in the New Innovation Landscape, Boston, Massachusetts: Harvard Business School, 2006, p. 75.

Coyle, Karen, "Linked data tools: connecting on the web", en: Library Technology Reports, May/june, 2012.

Isaac, Antoine, Waites, William, Young, Jeff et al., Library Linked Data Incubator Group: Datasets, Value Vocabularies, and Metadata Element Sets, w3C IncubatorGroupReport 25 October 2011, disponible en: http://www.w3.org/2005/Incubator/lld/XGR-lldvocabdataset-20111025/

Library of Congress, Bibliographic Framework as a Web of Data: Linked Data Model and Supporting Services, Library of Congress: Washington, DC, 2012.

Morales del Castillo, José Manuel, Hacia la biblioteca digital semántica, Gijón: TREA, 2001, p. 80.

Pesset, Fernanda, Ferrer-Sapena, Antonia y Subirats Coll, Imma, "Open data y linked open data: su impacto en el área de bibliotecas y documentación”, en El profesional de la información, Vol. 20, Núm. 2, 2011, p. 169.

Ryszard Kruk, Sebastian, "Goals of semantic digital libraries", en: Sebastian Ryszard Kruk, Bill McDaniel (eds.), Semantic digital libraries, Berlin: Springer, 2009, p. 72.

Semantic Web Builder, Quiénes somos, disponible en: http://www. semanticwebbuilder.org.mx/en/swb/SWB_Platform 


\section{Consideraciones finales}

través de los textos que se agrupan en la presente obra se
refleja el abanico de aspectos que deben ser considerados
al momento de diseñar una biblioteca digital académica. Puesto que la biblioteca digital en Bibliotecología y Estudios de la Información se construye con la participación de especialistas en el manejo de la información, se trata de tomar en cuenta aquellos aspectos que se consideran esenciales para su buen funcionamiento.

Sin duda hay muchos otros temas, además de los que aquí se presentan, pero, como se mencionó en la introducción, el objetivo de esta obra es mostrar un panorama amplio del cual se parta para establecer las tareas necesarias para llevar a buen término la creación de la biblioteca digital.

En este escenario general se desarrollaron los elementos básicos de los que se compondrá una $\mathrm{BD}$, así como las políticas generales que deben desarrollarse para la biblioteca digital funcione adecuadamente. Pero sobre todo se parte de la premisa de que sin contenidos digitales organizados no hay una biblioteca, sino un cúmulo de herramientas tecnológicas.

Es así como gran parte de las contribuciones se centran en esos contenidos digitales, sus características y las formas en que pueden organizarse y recuperarse. Hablar de la fotografía digital y su organización a través del uso de metadatos, el desarrollo de colecciones de libros electrónicos, la generación de publica- 
ciones digitales y el Linked Open Data como alternativa para su recuperación en la biblioteca digital académica, alude a las tendencias actuales que nos auxilian en la constitución de colecciones digitales.

Está claro que, a partir de la consideración de cada uno de estos aspectos, la biblioteca digital que se diseña podrá establecerse bajo bases sólidamente analizadas, ya que cada uno de los autores ataca un problema de su especialidad y lo relaciona con los otros, en un intento por darle unidad a la biblioteca que se pretende consolidar.

Georgina Araceli Torres Vargas 
Biblioteca Digital Académica en Bibliotecología y Estudios de la Información. La edición consta de 50 ejemplares. Coordinación editorial, Carlos Ceballos Sosa; revisión especializada, Francisco Xavier Gonzáles y Ortiz; formación editorial y revisión de pruebas, Risorsa, S.A de C.V. Instituto de Investigaciones Bibliotecológicas y de la Información/UnAM. Fue impreso en papel cultural de 90 g. en Arte Gráfico y Sonoro, Retorno de Amores 14-102, Colonia Del Valle, Delegación Benito Juárez, México, D.F. Se terminó de imprimir en el mes de diciembre de 2013. 